ORNL/TM-1999/103

Chemical Technology Division

\title{
Hydraulic Performance and Gas Behavior of a Tall Crystalline Silicotitanate Ion-Exchange Column
}

\author{
T. D. Welch \\ K. K. Anderson \\ R. D. Hunt \\ D. A. Bostick \\ R. Lenarduzzi ${ }^{\dagger}$ \\ T. A. Dillow \\ A. J. Mattus \\ M. W. Geeting* \\ P. A. Taylor \\ W. R. Wilmarth ${ }^{\ddagger}$ \\ * High-Level Waste Division, Westinghouse Savannah River Company
${ }^{\dagger}$ Instrumentation and Controls Division, ORNL
${ }^{\star}$ Savannah River Technology Center
}

February 2000

\author{
Prepared by \\ OAK RIDGE NATIONAL LABORATORY \\ Oak Ridge, Tennessee 37831-6285 \\ managed by \\ LOCKHEED MARTIN ENERGY RESEARCH CORP. \\ for the \\ U.S. DEPARTMENT OF ENERGY \\ under contract DE-AC05-96OR2246
}




\section{CONTENTS}

LIST OF TABLES

LIST OF FIGURES vii

EXECUTIVE SUMMARY ix

1. INTRODUCTION

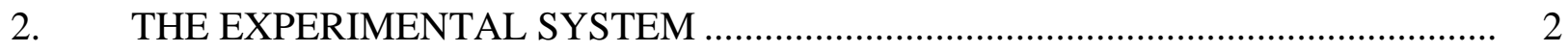

2.1 CST ION-EXCHANGE MATERIAL …………………………………….... 2

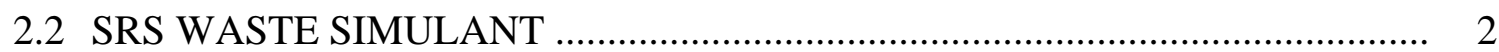

2.3 EQUIPMENT .................................................................................... 3

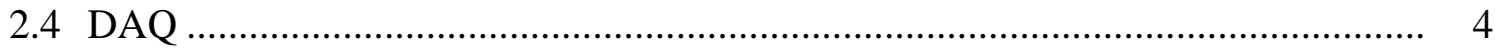

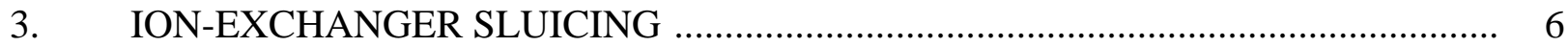

3.1 SLUICING CST INTO THE COLUMN ……………................................... 6

3.2 SLUICING CST FROM THE COLUMN ………............................................... 8

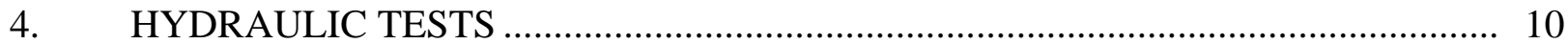

4.1 HYDRAULIC TEST 1: STARTUP........................................................... 10

4.2 HYDRAULIC TEST 2: STEADY FLOW, INCREASING PRESSURE DROP . 11

4.3 HYDRAULIC TEST 3: CONTINUATION AT $5 \mathrm{~cm} / \mathrm{min}$................................. 13

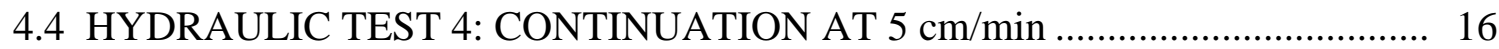

4.5 HYDRAULIC TEST 5: BED EXPANSION ………..................................... 18

4.6 HYDRAULIC TEST 6: FINAL TEST AFTER BED EXPANSION ................... 20

4.7 EVALUATION OF HYDRAULIC TEST DATA …………….......................... 20

5. LABORATORY GAS TESTS …………………........................................... 23

5.1 BATCH TESTS OF HYDROGEN PEROXIDE DECOMPOSITION .................. 23

5.2 HYDROGEN PEROXIDE ISOTHERM.......................................................... 26

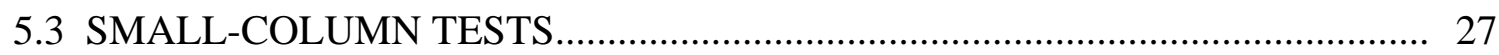

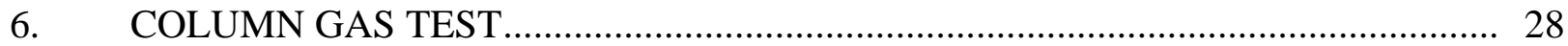

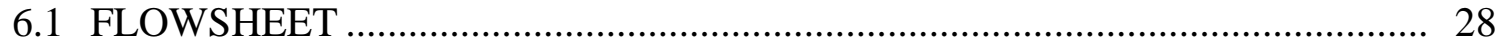

6.2 NITRITE EFFECT UPON CHEMICAL ANALYSIS ………........................... 29

6.3 STARTUP: DISAPPEARING PEROXIDE........................................................ 29

6.4 SYSTEM MODIFICATION AND RESTART ……….................................... 31

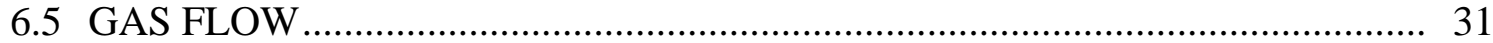

6.6 PRESSURE DROP INCREASE WITH GAS INVENTORY ............................ 35

7. RESULTS FROM ANCILLARY TEST AND ANALYSES..................................... 37

7.1 PARTICLE-SIZE DETERMINATION ………….......................................... 37

7.2 PARTICLE ANALYSIS ......................................................................... 40

7.3 INTERACTION OF HYDROGEN PEROXIDE WITH CST ............................. 42

7.4 BED-LOAD DISTRIBUTION.................................................................. 45 
8. CONCLUSIONS AND RECOMMENDATIONS …...................................... 48

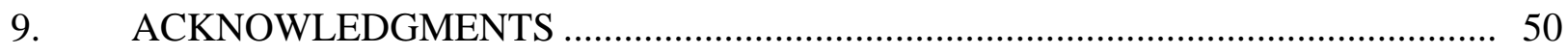

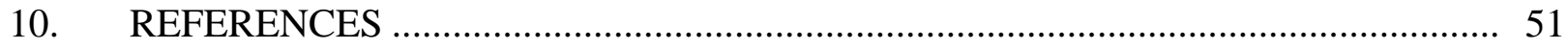

Appendix A. EQUIPMENT AND INSTRUMENTATION ....................................... A-1

Appendix B. SOLIDS FORMATION …............................................................ B 


\section{LIST OF TABLES}

\section{Table}

Page

2.1 SRS average waste composition ................................................................ 2

3.1 CST bed height in column during backwashing .......................................... 6

5.1 CST, nitrite-free simulant, and peroxide used in the batch gas-generation tests ......... 25

6.1 Conditions for column gas test ............................................................... 29

6.2 Hydrogen peroxide supply concentration after restart with hydrogen peroxide addition closer to the top of the column............................................ 34

7.1 Weight distribution of CST at the top port of the column ................................... 37

7.2 Overall sieve analysis results for CST column samples .................................... 39

A.1 Descriptions of equipment and instrumentation ........................................... A-4

A.2 Pressure instrumentation (gas test configuration, after 8/30/99) ............................ A-7

A.3 Temperature, flow, and weight instruments .................................................. A-8

B.1 Savannah River "average" waste simulant at $25^{\circ} \mathrm{C}:\left[\mathrm{Na}^{+}\right]=6.4 \mathrm{M}$;

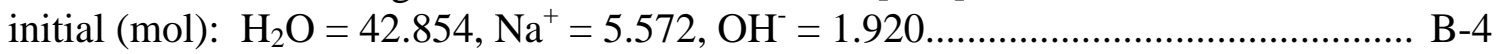

B.2 Savannah River "average" waste simulant at $25^{\circ} \mathrm{C}$ diluted with water

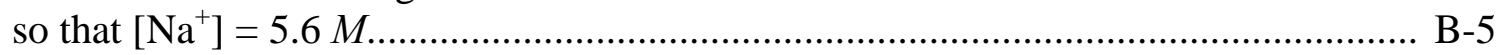

B.3 Savannah River "average" waste simulant at $25^{\circ} \mathrm{C}$ diluted with water and $\mathrm{NaOH}$ so that $\left[\mathrm{Na}^{+}\right]=5.6 \mathrm{M}$ with no additional solids .................................... B-5

B.4 Savannah River "average" waste simulant at $25^{\circ} \mathrm{C}$, silicon species

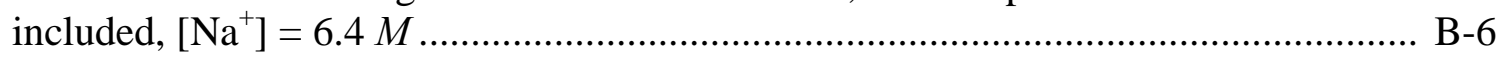

B.5 Savannah River "average" waste simulant diluted from $\left[\mathrm{Na}^{+}\right]=6.4 \mathrm{M}$ to $\left[\mathrm{Na}^{+}\right]=5.6 \mathrm{M}$ with water and $\mathrm{NaOH}$, silicon species included.

B.6 Savannah River "average" waste simulant diluted from $\left[\mathrm{Na}^{+}\right]=6.4 \mathrm{M}$ to $\left[\mathrm{Na}^{+}\right]=5.6 \mathrm{M}$ with only water, silicon species included. 


\section{LIST OF FIGURES}

Figure

Page

2.1 Simplified flowsheet showing the configuration for the gas-behavior tests.............. 4

2.2 Test system process and instrumentation diagram showing the hydraulic configuration....

3.1 Bed expansion during the backwashing of Batch 1.

3.2 Turbidity of effluent water during backwashing

Pressure at the top of the column during sluicing

4.1 Pressure drop in bed, test 1

4.2 Pressure drop across bed interface, test 1 . .

Pressure drop across the Johnson screen, test 1.

4.4 Pressure drop in bed, test 2.

Pressure drop across bed interface, test 2.

4.6 Pressure drop across the Johnson screen, test 2 ......................................... 14

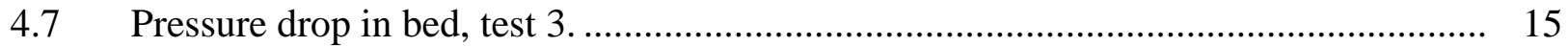

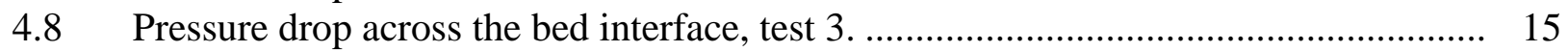

4.9 Pressure drop across the Johnson screen, test 3 ............................................. 16

4.10 Pressure drop in bed, test 4 ....................................................................... 17

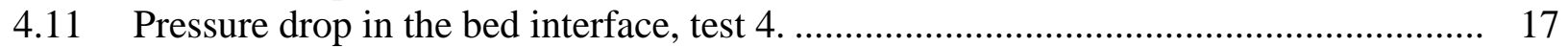

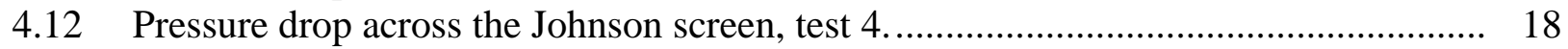

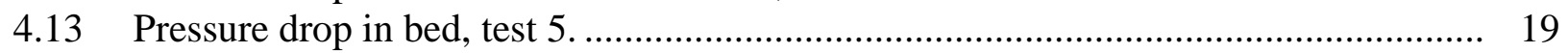

4.14 Pressure drop across bed interface, test 5 ................................................ 19

4.15 Pressure drop across the Johnson screen, test 5............................................. 20

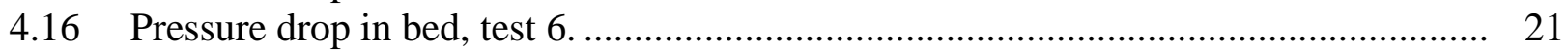

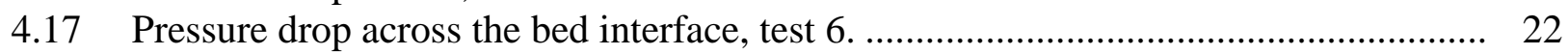

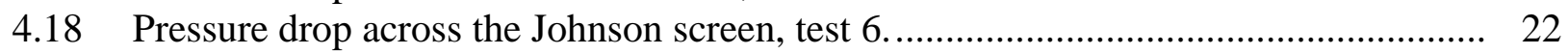

5.1 A pair of reaction flasks (right) and manometers (left) used to measure gas generation by hydrogen peroxide decomposition.

5.2 Initial gas generation as a function of peroxide concentration and

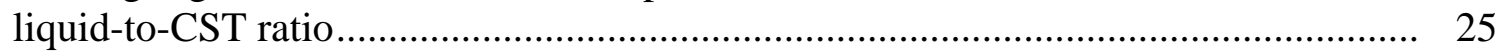

$5.3 \quad$ Peroxide adsorption isotherm .................................................................... 26

5.4 Decomposition and adsorption of peroxide as a function of time .......................... 27

6.1 Simplified flowsheet showing the configuration for the gas-behavior tests............... 28

6.2 Cloud of fine solids observed above the bed when the feed was stopped .................. 30

6.3 Disapearance of hydrogen peroxide from column simulant and from fresh SRS simulant.............................................................................. 31

6.4 Feed introduced through the $1 / 4$-in. tubing to just above the bed............................... 32

6.5 Peroxide concentration in the feed and the volume of gas carried

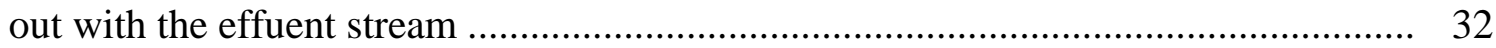

6.6 Gas voids visible at the column wall .............................................................. 33

6.7 Erratic hydrogen peroxide flow rate ........................................................ 34

6.8 Pressure drop in bed during gas test ............................................................ 35

6.9 Pressure drop early in the test during initial flow rate calibrations and effect of sampling 
6.10 Pressure drop in bed after feed was introduced at the top of the bed

7.1 Particle-size distribution of CST samples collected after backwashing and samples from the source barrel ....

7.2 Comparison of particle-size distribution of CST samples from the top and bottom of the column before unloading

7.3 SEM photomicrograph of baseline CST lot no. $999098810006 . .$. 40

7.4 Magnified view of baseline CST particle

7.5 SEM photomicrograph of particles collected from the top of the bed after hydraulic test 4 .

7.6 SEM photomicrograph of CST collected from near the top of the column just before unloading.

7.7 SEM photomicrograph of CST collected from the bottom of the column just before unloading....

7.8 SEM photomicrograph of precipitate nodules containing aluminum and silica on the surface of CST collected from the bottom of the column

7.9 Stress variation in 60-in.-diam column.

7.10 Stress variation in 3-in.-diam column [PC 25] ................................................ 47

A-1 Process and instrumentation diagram showing the gas test configuration 


\section{EXECUTIVE SUMMARY}

Crystalline silicotitanate (CST) sorbent is one of several technologies being evaluated by the Savannah River Site (SRS) for removing cesium from high-level tank-waste supernatant. As currently envisioned, three large 5-ft-diam, 20-ft-high ion-exchange columns will be operated in series at a superficial velocity of $4.1 \mathrm{~cm} / \mathrm{min}$. The CST will be subjected to a high radiation field from the sorbed cesium. The tests described in this work were conducted to evaluate column hydraulics, to identify changes in the CST particles during operation, to explore how radiolytic gases generated during operation behave, and to demonstrate sluicing of CST into and out of columns.

To accomplish these objectives, a 20-ft tall, 3-in.-diam column was constructed from clear polyvinyl chloride and instrumented to measure pressures, temperatures, and flows. Tests were conducted using SRS "average" simulant with superficial velocities in the range of 4.1 to $5.0 \mathrm{~cm} / \mathrm{min}$. The diameter of the column was selected by considering the trade-off between realistic simulation relative to the test objectives and the cost of materials, equipment, and operation.

The column was loaded with CST by sluicing, and fine particles were removed by backwashing. Bed pressure drops were measured under various operating conditions. Batch, small-column, and large-column tests were conducted to evaluate gas effects. The CST ion exchanger was removed from the column by sluicing in the final test.

CST was easily sluiced to and from the ion-exchange column using water and air. The CST was added to the column in three batches, and the column was backwashed after each batch to remove any fines generated during sluicing. The column was backwashed with tap water at flow rates up to $1.2 \mathrm{~L} / \mathrm{min}$ after the first and second batches of CST were added to the column and at rates up to $0.6 \mathrm{~L} / \mathrm{min}$ after the third batch was added. The CST bed was expanded by at least $50 \%$ during the first and second backwashes, but by only $20 \%$ during the third because of a lack of free space in the column.

The effect of flow rate on pressure drop through the column was measured. The column pressure drop for the first four tests ranged from 17 to $23 \mathrm{psi}$. The pressure drop at the top of the bed, where a layer of fines and fragments of CST and other materials existed, accounted for 60 to $70 \%$ of the pressure drop. After the bed was expanded to redistribute these layers, the pressure drop stabilized at about $7 \mathrm{psi}$ for a flow rate of $225 \mathrm{~mL} / \mathrm{min}(5-\mathrm{cm} / \mathrm{min}$ superficial velocity). The pressure drop across the column calculated by the Blake-Kozeny equation (7.75 psi) is in good agreement with the measured 7.4-psi pressure drop in hydraulic test 6 . The pressure gradients in the bed were relatively constant and varied from 0.35 to $0.45 \mathrm{psi} / \mathrm{ft}$. No channeling was detected. The pressure drop across the Johnson screen remained constant throughout the six tests, ranging from 0.45 to $0.55 \mathrm{psi}$, indicating that there was no accumulation of fines on the screen.

To test gas behavior in the column, a method to simulate radiolytic gas generation was developed. After evaluating several alternatives, oxygen production by the decomposition of hydrogen peroxide was selected. The reaction rate of hydrogen peroxide decomposition was 
determined from batch and small-column laboratory experiments. In addition to catalyzing the hydrogen peroxide decomposition reaction, CST also adsorbs hydrogen peroxide. Thus, hydrogen peroxide decomposition not only simulates radiolytic gas generation but also simulates the movement of the gas-generation front caused by ${ }^{137} \mathrm{Cs}$ loading down through the bed. The laboratory studies also showed that peroxide leaches metals from the CST. These findings may have implications in CST applications because one of the products of radiolysis is hydrogen peroxide.

The gas-generation test was conducted to provide information on how gases that are produced in the column are retained and released by the bed. The target gas-generation rate was $82 \mathrm{~cm}^{3} / \mathrm{h}$, based on the maximum expected gas generation in an actual system with SRS high-nitrate supernatant. However, a gas-generation range of 40 to $320 \mathrm{~cm}^{3} / \mathrm{h}$ was used in planning the test to allow for the range of cesium concentrations expected in the actual waste. Column differential pressures, the volume of gas generated, and the column bed heights were measured. The bed was also monitored for bubble formation and gas accumulation. The test was run at a nominal superficial liquid velocity of $4.1 \mathrm{~cm} / \mathrm{min}$. Hydrogen peroxide loaded on the CST bed relatively quickly; about $9.5 \mathrm{~h}$ after peroxide was introduced at the top of the bed via a modified feed configuration, the first measurable volume of gas was observed in the effluent. Gas bubbles seen at the inside surface of the column wall gave a visual indication of the progress of the gas wave down the column.

Gases generated in the column were swept out with the effluent at both the target rate of $82 \mathrm{~cm}^{3} / \mathrm{h}$ and at $1400 \mathrm{~cm}^{3} / \mathrm{h}$, more than 17 times the target rate. Gases did not coalesce, rise in the column, or disrupt the bed. The bed did not expand while the column was operated in downflow, even at gas-evolution rates 16 times the target rate of $82 \mathrm{~cm}^{3} / \mathrm{h}$. The bed pressure drop at a superficial velocity of $4.1 \mathrm{~cm} / \mathrm{min}$ was in the 8- to 9-psig range with gas in the bed, compared with the 3.5- to 4.5-psig range without gas. From the Blake-Kozeny equation, this corresponds to a gas void fraction of about $7 \%$. After flow was shut off, gas accumulated at the top of the column, and a volume equivalent to about $3 \mathrm{vol} \%$ of the bed was released. After a gas inventory had been established in the column (i.e., once gas voids form in the column), the pressure drop was only weakly affected by the gas-generation rate.

Gases were effectively cleared from the column with the effluent stream under flowing conditions. The lack of bed expansion and the limited buildup of gas inventory in the column suggest that gases remain in the liquid phase as tiny bubbles, which is beneficial from the standpoint of heat removal and safety. After shutdown, part of the gas inventory disengages from the bed and rises in streams of bubbles from the top of the bed. The column was able to handle 16 times the design-basis-maximum gas-generation rate without apparent disruption of the bed.

This study was based on a 16-ft-tall bed column design with a superficial velocity of $4.1 \mathrm{~cm} / \mathrm{min}$. If the optimal design proves to be different, changes in mass transfer, heat transfer, and hydraulics will need to be evaluated. 
Prior to sluicing the CST from the column, the supernate simulant in the column was displaced with $2 M \mathrm{NaOH}$, and the $\mathrm{NaOH}$ was then displaced with deionized water. Using water, rather than supernate simulant, to sluice the CST facilitated handling of the spent CST. The two-step displacement process was used to avoid possible precipitation of aluminum hydroxide from the supernate simulant if the $\mathrm{pH}$ of the solution was lowered during mixing with the water.

The column was pressurized, and then the bottom sluice valve was opened. The CST and water flowed up through the 1-in. sluice line to the level of the top of the column and then back down into a plastic tank. Because of the restricted air supply, the CST and water flowed rather slowly from the column into the collection tank. The water interface moved slightly faster than the CST interface, leaving about $17 \mathrm{~cm}$ of CST in the bottom of the column after the first sluicing. The sluicing took $2.3 \mathrm{~min}$; therefore, the average flow rate was $10 \mathrm{~L} / \mathrm{min}$, and the average velocity in the sluice line was $33 \mathrm{~cm}^{3} / \mathrm{s}$. Most of the remaining CST was removed in two subsequent sluices. The amount of residual ion exchanger can be reduced by placing the bottom of the dip tube closer to the bottom of the column.

Leaching of metals from the CST by hydrogen peroxide was observed at the relatively high peroxide concentrations used for gas generation. Hydrogen peroxide is a radiolysis intermediate; however, the radiolytic hydrogen peroxide concentration will be much lower than the concentrations used in these tests.

Precipitates of solids containing aluminum and silicon occurred in a stagnant area below the Johnson screen, where residual water was known to have been present during the early tests. Conditions leading to precipitation should be avoided.

The CST appears to have remained intact, with little breakage or attrition, after 2 months in the column. It did appear that some constituents were leached from the CST by the simulant. Potential performance impacts of this leaching should be investigated. 


\section{INTRODUCTION}

The Savannah River Site (SRS) is evaluating technologies for removing ${ }^{137} \mathrm{Cs}$ from the supernatant solutions stored in the high-level waste tanks at the site. The first industrial application of crystalline silicotitanate (CST) is currently under way at Oak Ridge National Laboratory (ORNL) to remove ${ }^{137} \mathrm{Cs}$ from liquid low-level waste. However, much larger volumes of waste are stored at SRS, and the SRS waste contains more radioactivity. This additional quantity of waste and its accompanying radioactivity will result in significantly different design requirements for the SRS ion-exchange system. The study summarized in this report was undertaken to evaluate the hydraulics of large-scale CST ion-exchange columns. This work was targeted to a Technical Task Request ${ }^{1}$ from SRS to address technical issues raised in the Science and Technology Roadmap ${ }^{2}$ and the Applied Technology Integration Scope of Work Matrix ${ }^{3}$ reports for the project.

Preliminary design of the CST system for the SRS application ${ }^{4}$ specified 5-ft-diam, 20-ft-tall columns containing a $16-\mathrm{ft}$ bed of ion-exchange material. A pilot-scale system was built at ORNL to test the hydraulics of CST in the full-scale system. Four system operations were performed: ion-exchanger loading, column backwashing, column operation, and CST unloading. The following parameters were evaluated: physical stability of CST, accumulation of gas in the column, and pressure drop across the ion-exchange bed. The determination of the amount of gas generated by radiolysis was estimated by Jacobs. 5 


\section{THE EXPERIMENTAL SYSTEM}

\subsection{CST ION-EXCHANGE MATERIAL}

The CST used for all of the tests was the commercial granular form of the sorbent, IONSIV® IE-911 (registered trademark of UOP LLC, Mt. Laurel, New Jersey), specifically, a sample from lot no. 999098810006. CST is a material that evolved through the combined efforts of Sandia National Laboratory, Texas A\&M University, and a Cooperative Research and Development Agreement with UOP. IONSIVR® IE-911 became commercially available in 1996 . The efficiency of this ion exchanger in cesium removal in high sodium concentrations made it a promising candidate among the cesium-removal technologies considered by the High-Level Waste Salt Disposition Team. The sorbent, as received, is slightly acidic and contains fines that are generated during shipping. The CST is pretreated with dilute $\mathrm{NaOH}$ to stabilize the CST at a $\mathrm{pH}$ of 13 and backwashed with water to remove fines. This pretreatment method was developed for the ongoing ORNL application.

\subsection{SRS WASTE SIMULANT}

An "average" SRS supernate simulant, with a total sodium concentration of 5.6 $M$, was used for these tests (Table 2.1). The recipe for this simulant was prepared by SRS. ${ }^{6}$ For the gas-behavior tests, the oxalate and sodium nitrite were replaced with sodium nitrate to avoid interference in the peroxide analysis.

Table 2.1. SRS average waste composition

\begin{tabular}{ll}
\hline Component & Average concentration $(M)$ \\
\hline $\mathrm{Na}^{+}$ & 5.6 \\
$\mathrm{Cs}^{+}$ & 0.00014 \\
$\mathrm{~K}^{+}$ & 0.015 \\
$\mathrm{OH}^{-}$ & 1.91 \\
$\mathrm{NO}_{3}{ }^{-}$ & 2.14 \\
$\mathrm{NO}_{2}{ }^{-}$ & 0.52 \\
$\mathrm{AlO}_{2}{ }^{-}$ & 0.31 \\
$\mathrm{CO}_{3}{ }^{2-}$ & 0.16 \\
$\mathrm{SO}_{4}{ }^{2-}$ & 0.15 \\
$\mathrm{Cl}^{-}$ & 0.025 \\
$\mathrm{~F}^{-}$ & 0.032 \\
$\mathrm{PO}_{4}{ }^{2-}$ & 0.010 \\
$\mathrm{C}_{2} \mathrm{O}_{4}{ }^{2-}$ & 0.008 \\
$\mathrm{SiO}_{3}{ }^{2-}$ & 0.004 \\
$\mathrm{MoO}_{4}{ }^{2-}$ & 0.0002 \\
\hline
\end{tabular}




\subsection{EQUIPMENT}

A simplified flowsheet for the ion-exchange test system is shown in Fig. 2.1. The system includes a 3-in-diam, 20-ft-tall column to model the SRS columns (5-ft-diam, 20-ft-tall column with a 16-ft adsorber bed). The system was operated at the flow rate corresponding to the design-basis superficial velocity of the full-scale SRS system. Figure 2.2 shows the piping and instrumentation diagram (P\&ID) for the hydraulic test configuration. The list of major equipment used in the system and the P\&ID showing the gas test configuration are included in Appendix A.

The column is a 20-foot-tall, 3-in.-diam clear polyvinyl chloride (PVC) pipe structure. It was filled to a height of $16 \mathrm{ft}$ with CST. Pressure sensors are located at 1-m intervals along the column. Flow meters are installed on the inlet and effluent lines. The major components in the system are the feed tank, the feed pump, the column, the Johnson screen, and the effluent tank.

The basic flow path for the simulant is from the feed tank to the top of the column. Simulant moves into the top, down through the column, and then out through the Johnson screen. The effluent flows into the effluent tank, where it drains by gravity back to the feed tank.

The base of the column body was constructed of a 3-in.-diam PVC cleanout plug with a threaded base that could be removed and replaced. A solid block of PVC stock was machined to fit tightly into the bottom portion of the cleanout, and varying heights were cut to allow different positions from the bottom of the Johnson screen and the unloading tube. This procedure provided the capability to vary the position of the dip tube relative to the column bottom during unloading scoping tests. The effluent flows through the Johnson screen into a clear PVC tubing at the base of the column and proceeds through a 1/4-in. stainless steel tube to the lower gasdisengagement vessel. This vessel was constructed using 11/2-in Plexiglas ${ }^{\mathrm{TM}}$ tubing capped at both ends. The stream then passes through $3 / 4-$ in. tubing to a $1-\mu \mathrm{m}$ bag filter. A bypass line was also installed with a 70-psig-rated pressure relief valve (PRV 3). The effluent flow rate was measured by a rotameter (FL3) in the hydraulic tests and by a turbine flow sensor (FL2) in the gas tests. The stream was then collected in a 15-gal catch tank placed on a weigh scale (WT 2). For some tests, tank contents were collected for incremental periods before being released back into the feed tank to obtain flow data during testing. In other tests, the flow passed through the tank without being accumulated. An overfill line was installed from the top of the effluent feed tank. The entire tall-column system was contained in a stainless steel pan (12 ft $\times 6 \mathrm{ft} \times 8 \mathrm{in}$. $)$.

Eight pressure sensors were located at $\sim 1-\mathrm{m}$ intervals along the length of the column. The sensors transmitted a signal to the Data Acquisition System (DAQ) and direct readout gauges at the column. The heights (in centimeters) of the pressure transducers (PTs) from the centerline of the discharge line were as follows (PT8 is located downstream from the Johnson screen):

$\begin{array}{lrrr}\text { PT1 } & 601.0 & \text { PT5 } & 199.5 \\ \text { PT2 } & 499.5 & \text { PT6 } & 97.5 \\ \text { PT3 } & 399.5 & \text { PT7 } & 0.0 \\ \text { PT4 } & 299.5 & \text { PT8 } & 0.0\end{array}$




\subsection{DAQ}

LabVIEW ${ }^{\mathrm{TM}}$ was chosen as the DAQ. Front-panel user interfaces were developed showing the column layout. All thermocouple, pressure transducer, and flow rates were monitored and recorded as needed. This setup gave the operator a quick overall view of the system on the computer screen. The analog inputs were temperature, pressure, and flow rate. The signal was conditioned by a 32-channel multiplexer. Shielded cables were installed to isolate noise and improve accuracy. The following is a list of data acquisition components:

- data acquisition card: PCI-MIO-16XE-10, $100 \mathrm{kHz}, 16$ bit, 16 channel;

- signal-conditioning components: 4-slot SCXI chassis, 32-channel multiplexer, cablemounted terminal block, feedthrough module for unused channels, process current resistor kit, front filler panel, rear filler panel;

- cables: shielded cable for SCXI chassis, 68-pin shielded cable for all analog inputs; and instrument rack: rack-mount kit for SCXI, panel cut for instrument display meters.

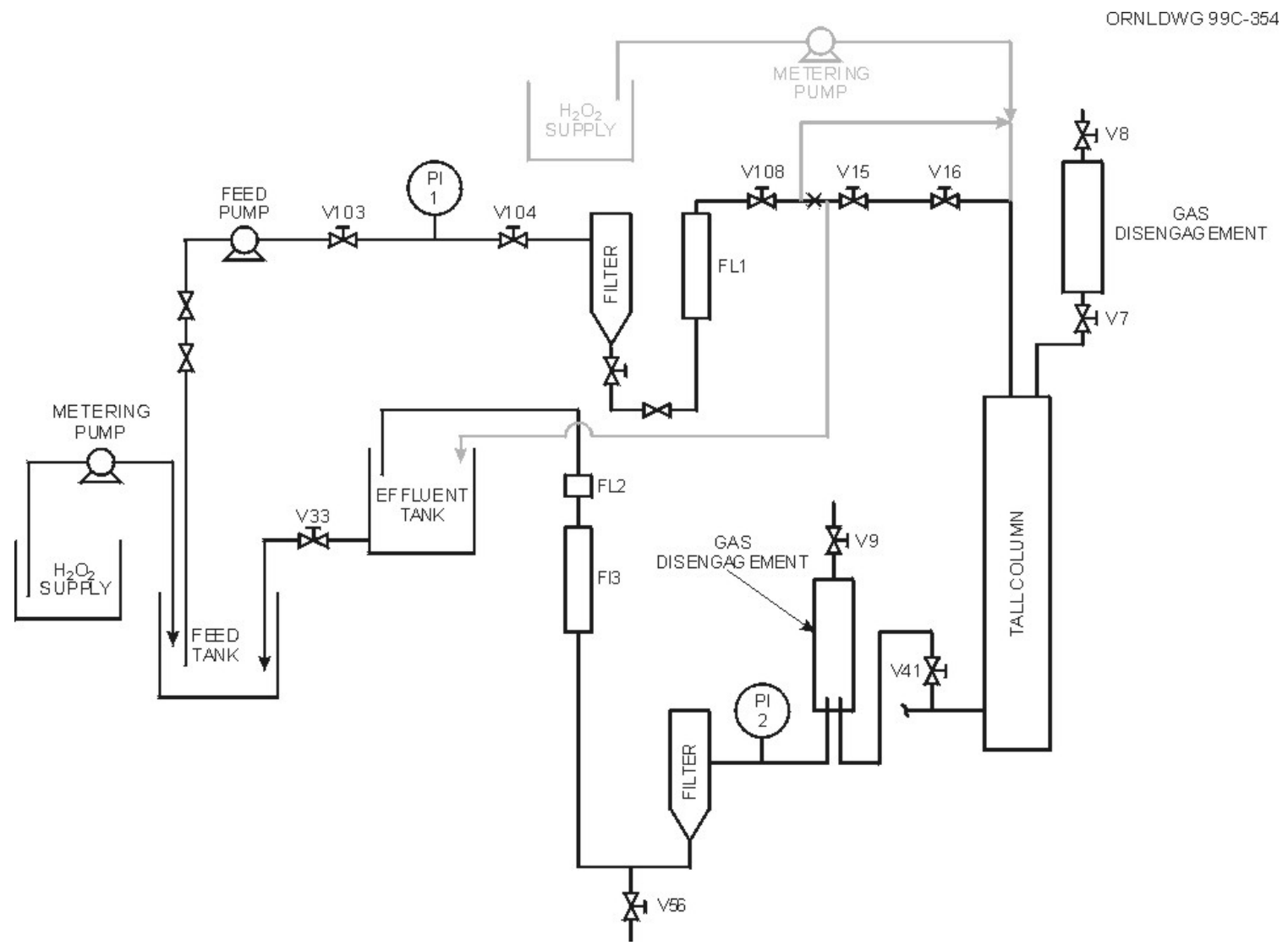

Fig. 2.1. Simplfied flowsheet showing the configuration for the gas-behavior tests. 


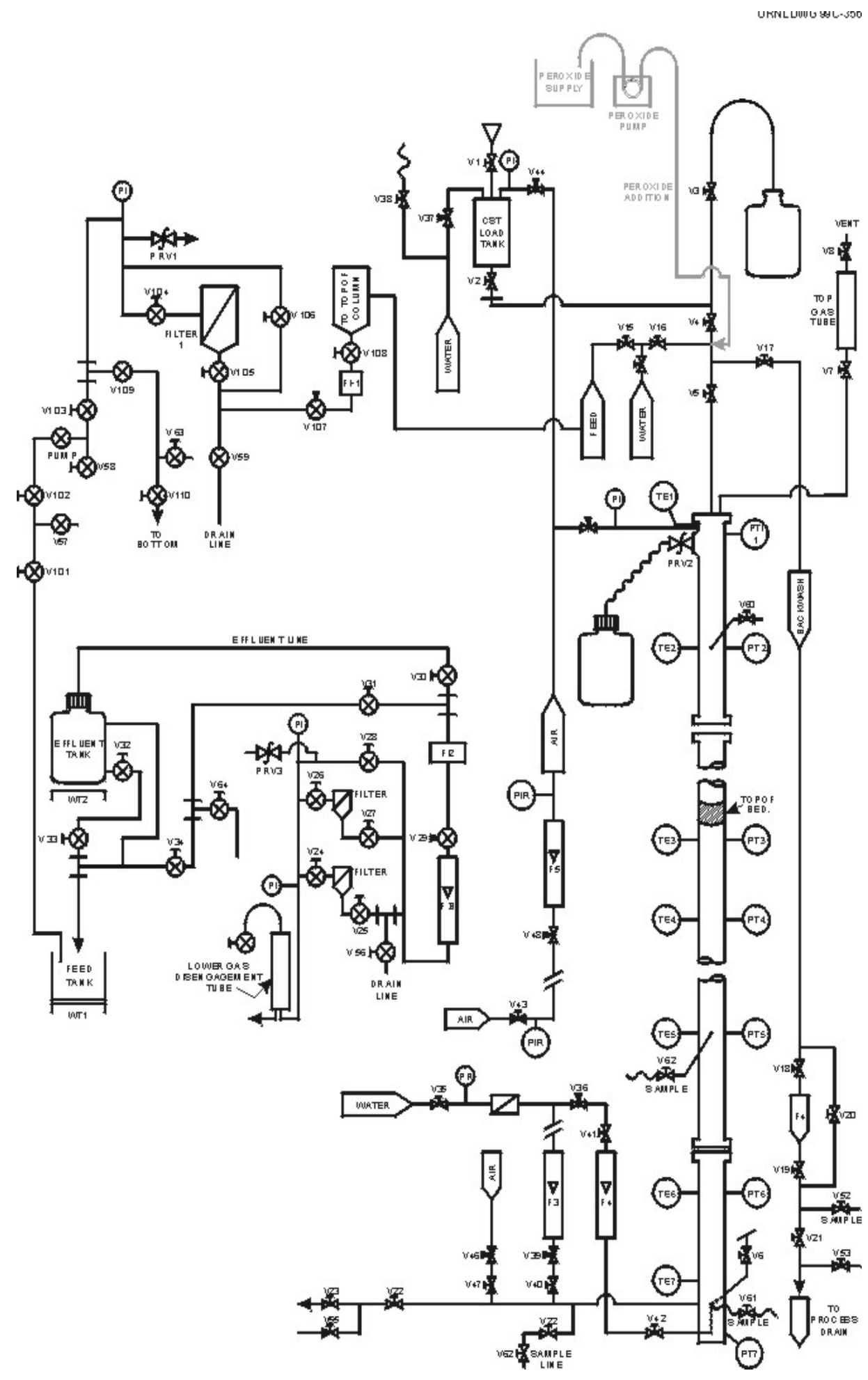

Fig. 2.2. Test system process and instrumentation diagram showing the hydraulic configuration. 


\section{ION-EXCHANGER SLUICING}

The CST used in these tests (IONSIV® IE-911) is easily sluiced to and from ion-exchange columns using water and air. ${ }^{7}$ The CST, as received, was slightly acidic and contained fines that were generated during shipping. The CST was pretreated by stabilizing the $\mathrm{pH}$ at 13.0 with dilute $\mathrm{NaOH}$ and then backwashing with water to remove any fines.

\subsection{SLUICING CST INTO THE COLUMN}

The material used in these tests was designated as lot no. 999098810006, which had been pretreated for the ORNL Cesium Removal Project. The CST was added to the column in three batches, and the column was backwashed after each batch to remove any fines generated during sluicing. The CST was rinsed into the load tank with water, the tank was pressurized to $20 \mathrm{psig}$ with air, and then the bottom valve of the tank was opened to sluice the CST into the column. Most of the CST was sluiced into the column during the first sluicing operation. However, the load tank had a flat bottom, so it was difficult to remove all of the CST from the tank. Five or six rinses, using a small amount of water and air pressure, were required to sluice the remaining CST into the column. The height of CST in the column was $158 \mathrm{~cm}$ after the first batch was added, $351 \mathrm{~cm}$ after the second batch, and $487 \mathrm{~cm}$ after the third batch.

The column was backwashed with tap water at flow rates up to $1.2 \mathrm{~L} / \mathrm{min}$ after the first and second batches of CST were added to the column and at rates up to $0.6 \mathrm{~L} / \mathrm{min}$ after the third batch was added. The CST bed was expanded by at least $50 \%$ during the first and second backwashes, but by only $20 \%$ during the third because of a lack of space in the column. Table 3.1 shows the average CST bed height at each flow rate used during backwashing, and Fig. 3.1 shows the percentage bed expansion.

Table 3.1. CST bed height in column during backwashing

\begin{tabular}{cccc}
\hline $\begin{array}{c}\text { Flow rate } \\
(\mathrm{L} / \mathrm{min})\end{array}$ & \multicolumn{3}{c}{ CST bed height in column $(\mathrm{cm})$} \\
\cline { 2 - 4 } & Batch 1 & Batch 2 & Batch 3 \\
\hline 0 & 156 & 351 & 487 \\
0.4 & 180 & 400 & 557 \\
0.6 & - & - & 580 \\
0.8 & 215 & 469 & - \\
1.0 & 231 & - & - \\
1.2 & 242 & 526 & - \\
\hline
\end{tabular}

A 1- $\mu \mathrm{m}$ pore-size bag filter was used to trap solids in the backwash water. The filter collected a total of $44.7 \mathrm{~g}$ (air-dried weight) of solids from all of the backwashes. Previous work at ORNL had shown that the fines generated from CST can be smaller than $1 \mu \mathrm{m}$. The effluent from the bag filter was cloudy, indicating that some solids were passing through the filter. The turbidity of the filtered backwash water was measured periodically to track the removal of fines from the CST. Figure 3.2 shows the measured turbidity during the backwashing of each batch of CST. The flow rates were changed several times during each backwashing, so the data should be considered only a qualitative view of the general trends. 


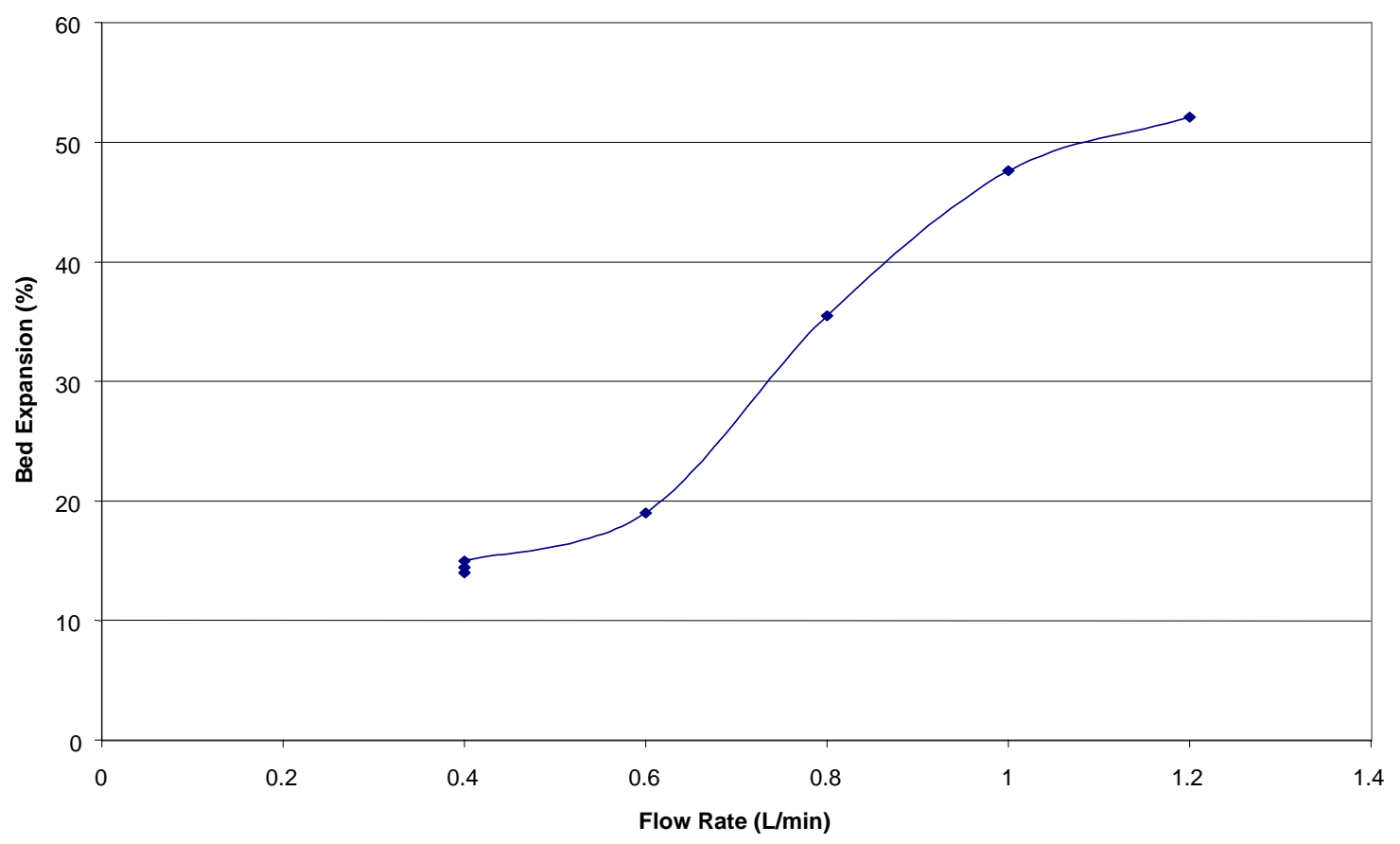

Fig. 3.1. Bed expansion during the backwashing of Batch 1.

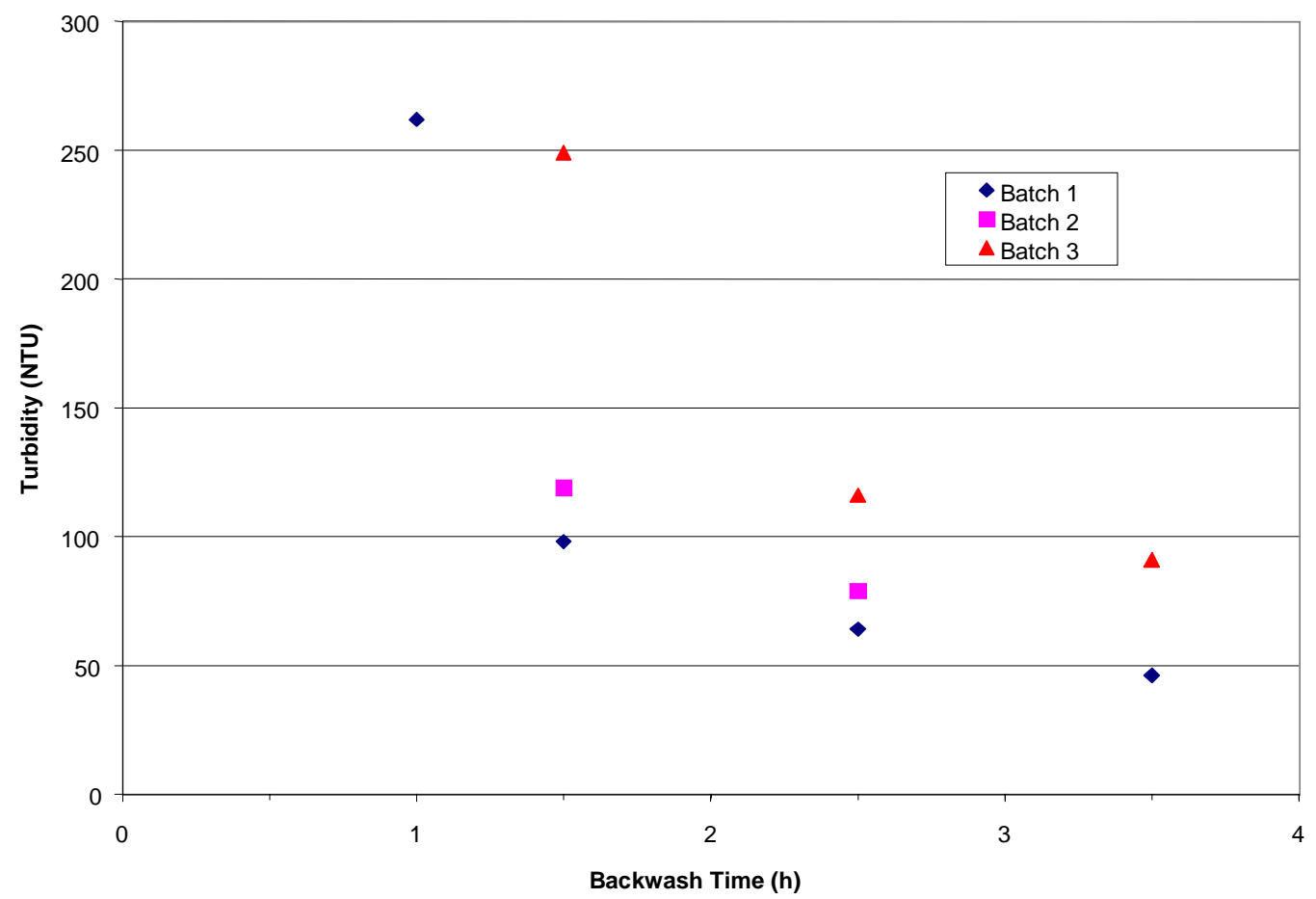

Fig. 3.2. Turbidity of effluent water during backwashing. 


\subsection{SLUICING CST FROM THE COLUMN}

The CST was removed from the column after the hydraulic and gas tests were completed. Before sluicing the CST from the ion-exchange column, the supernate simulant in the column was displaced with $2 M \mathrm{NaOH}$, and the $\mathrm{NaOH}$ was then displaced with deionized water. The use of water, rather than supernate simulant, to sluice the CST facilitated handling of the spent CST. The two-step displacement process was used to avoid possible precipitation of aluminum hydroxide from the supernate simulant if the $\mathrm{pH}$ of the solution was lowered during mixing with the water.

The bed height of the CST in the column was $460 \mathrm{~cm}$ before sluicing, and the water level was at $520 \mathrm{~cm}$. The total volume of CST and water in the column was about $24 \mathrm{~L}$. Air was supplied to the top of the column at $40 \mathrm{psig}$, through a $1 / 4$-in. plastic line with a needle valve. The small line and valve restricted the flow rate of the air to the column. The column was pressurized, and then the bottom sluice valve was opened. The CST and water flowed up through the 1-in. sluice line to the level of the top of the column and then back down into a plastic tank. Because of the restricted air supply, the CST and water flowed rather slowly from the column into the collection tank. The water interface moved slightly faster than the CST interface, leaving about $17 \mathrm{~cm}$ of CST in the bottom of the column after the first sluicing. The sluicing took $2.3 \mathrm{~min}$; therefore, the average flow rate was $10 \mathrm{~L} / \mathrm{min}$, and the average velocity in the sluice line was $33 \mathrm{~cm} / \mathrm{s}$. Figure 3.3 shows the air pressure in the top of the column during the sluicing operation.

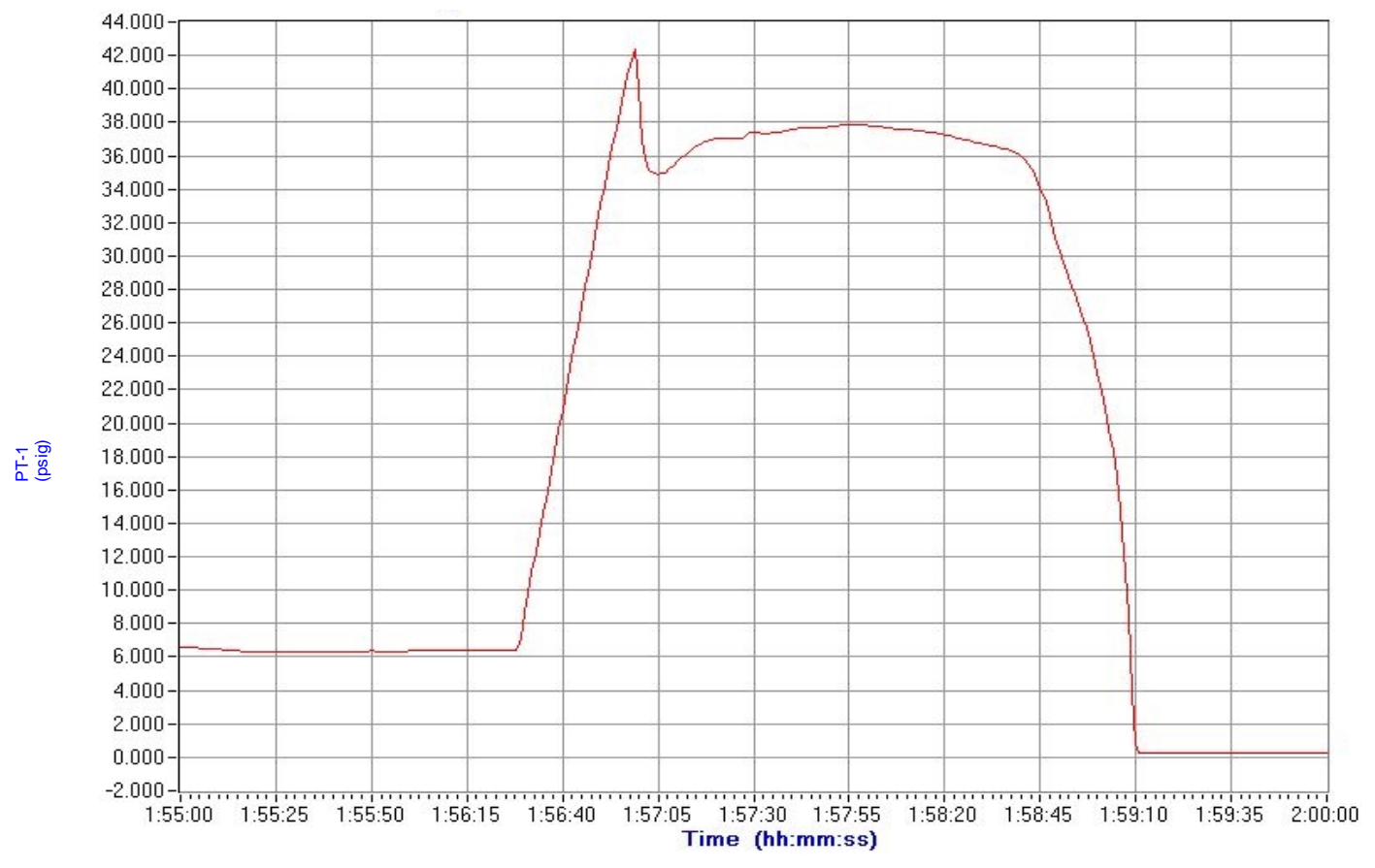

Fig. 3.3. Pressure at the top of the column during sluicing. PT1 $=$ pressure at the top of the column. 
The pressure in the column increased after the air supply was turned on, up to about $42 \mathrm{psig}$, and then decreased after the bottom sluice valve was opened. The pressure remained fairly constant during most of the sluicing operation, as the air displaced the CST and water, and then decreased rapidly after all of the water was displaced and the air could flow through the remaining CST. The air was turned off at about 1:59:00 (hh:mm:ss), as seen in Fig. 3.3.

About $5 \mathrm{~L}$ of deionized water was added back to the column (to a height of $110 \mathrm{~cm}$ ), and the sluicing was repeated. A small amount of CST was left around the Johnson screen, about $1.5 \mathrm{in}$. measured from the column bottom, after the second sluicing. About $7 \mathrm{~L}$ of deionized water was added to the column (height of $150 \mathrm{~cm}$ ), and the sluicing was repeated. Approximately $1 \mathrm{in}$. of CST was left in the bottom of the column, below the level of the Johnson screen and corresponding to the bottom of the sluice line. Three sluices were also routinely used to remove spent CST from the 30-cm-ID by 90-cm-tall columns used in the Cesium Removal Project. ${ }^{7}$ The results of these tests show that even a very tall bed of CST can be easily sluiced from a column using water and moderate air pressure. The CST and water flow easily, even at relatively low velocities. 


\section{HYDRAULIC TESTS}

The test column was operated to obtain data on pressure drop through the column, changes in column pressure drops with time, and the effect of flow rate on pressure drop. Results also gave an indirect indication of the generation and accumulation of fines. Other observations relating to the operation and flow characteristics of the column were also noted.

The tests were run in the normal configuration for downflow ion-exchange columns, using SRS average simulant. The flow path for the simulant was from the feed tank to the top of the column, through the column, and then through the Johnson screen. The effluent flows into the effluent tank, from which it drains by gravity back to the feed tank.

The column pressure readings presented herein were adjusted during posttest data reduction to subtract the static head pressure at each sensor height in the column. The static head adjustment accounts for the height of simulant each sensor records and the height of the effluent discharged into the effluent tank.

The starting height of CST in the column was $485.5 \mathrm{~cm}$. Thus, the interface between simulant and the CST bed occurred between pressure sensors PT2 and PT3. PT7 is at the bottom of the bed, and PT8 is on the discharge side of the Johnson screen.

The intent of the hydraulic tests was to operate for a sufficient period of time to determine trends. Ideally, one would like to operate continuously for an entire cycle (3-6 months). However, scheduling and budget constraints required that the scope of operations for the tests be limited. Each test had basically the same objective: to monitor hydraulic performance with time.

However, the first test included replacement of $\mathrm{NaOH}$ with simulant, and the fifth and sixth tests were conducted after the bed had been expanded. The column was operated for six shifts rather than continuously, accumulating $65 \mathrm{~h}$ of operation. The CST was exposed to SRS simulant for 2 months.

Pressure drop data were critical in three sections of the column: along the full length of the column (PT2 to PT7), across the simulant-CST bed interface (PT2 to PT3), and across the Johnson screen (PT7 to PT8). The figures in this section provide details.

\subsection{HYDRAULIC TEST 1: STARTUP}

The first test simulated SRS system startup. During the initial portion of the test, simulant displaced the $2 \mathrm{M} \mathrm{NaOH}$, which was in the column. The $2 \mathrm{M} \mathrm{NaOH}$ was introduced after sluice water to avoid precipitation from the simulant. The pump was stopped several times to remove the $\mathrm{NaOH}$ from the effluent tank and to add simulant to the feed tank. The feed pump was monitored during the run, and the pump setting was adjusted to obtain a flow rate of $\sim 225 \mathrm{~mL} / \mathrm{min}(5-\mathrm{cm} / \mathrm{min}$ superficial velocity). This was the flow rate maintained during the last $45 \mathrm{~min}$ of the test. Figure 4.1 shows the pressure drop across the 16-ft bed during the test. Midway through the test, discoloration was noted at the top of the bed. A thin layer ( 1/16 in.) 
of light-brown or tan material was observed. A sample from the top of the bed was collected after test 4 and analyzed. Section 7 provides a discussion of the results from this analysis.

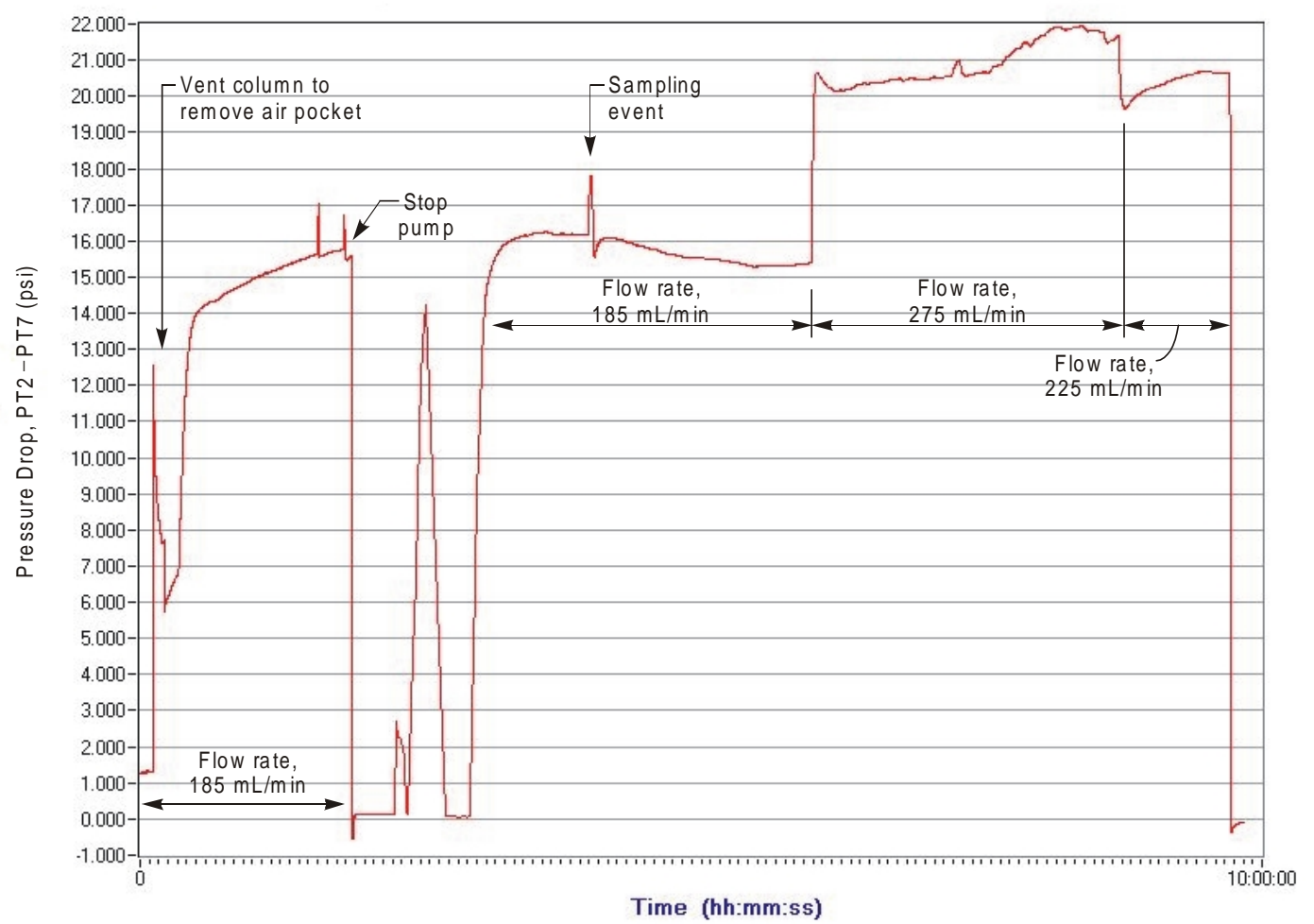

Fig. 4.1 Pressure drop in bed, test 1. PT2 = pressure above the bed; PT7 = pressure at the bottom of the column.

Figure 4.2 shows the pressure drop across the simulant-CST bed interface. The data indicate that the pressure drop across the top of the bed accounted for about $70 \%$ of the pressure drop for the entire bed (Fig. 4.1). The pressure drop across the Johnson screen at the desired flow rate $(\sim 225 \mathrm{~mL} / \mathrm{min})$ was slightly less than $0.5 \mathrm{psig}$ as expected (Fig. 4.3).

\subsection{HYDRAULIC TEST 2: STEADY FLOW, INCREASING PRESSURE DROP}

Hydraulic test 2 was a continuation of hydraulic test 1 to simulate SRS column operations initially after startup at a superficial velocity of $5 \mathrm{~cm} / \mathrm{min}$ (flow rate of $225 \mathrm{~mL} / \mathrm{min}$ ). The discolored band at the top of the bed appeared to have a lighter color than when it was first noted during run 1. The material at the top of the bed appeared, based on observation, to be of a finer particle size. It was later determined (see Sect. 7 for 


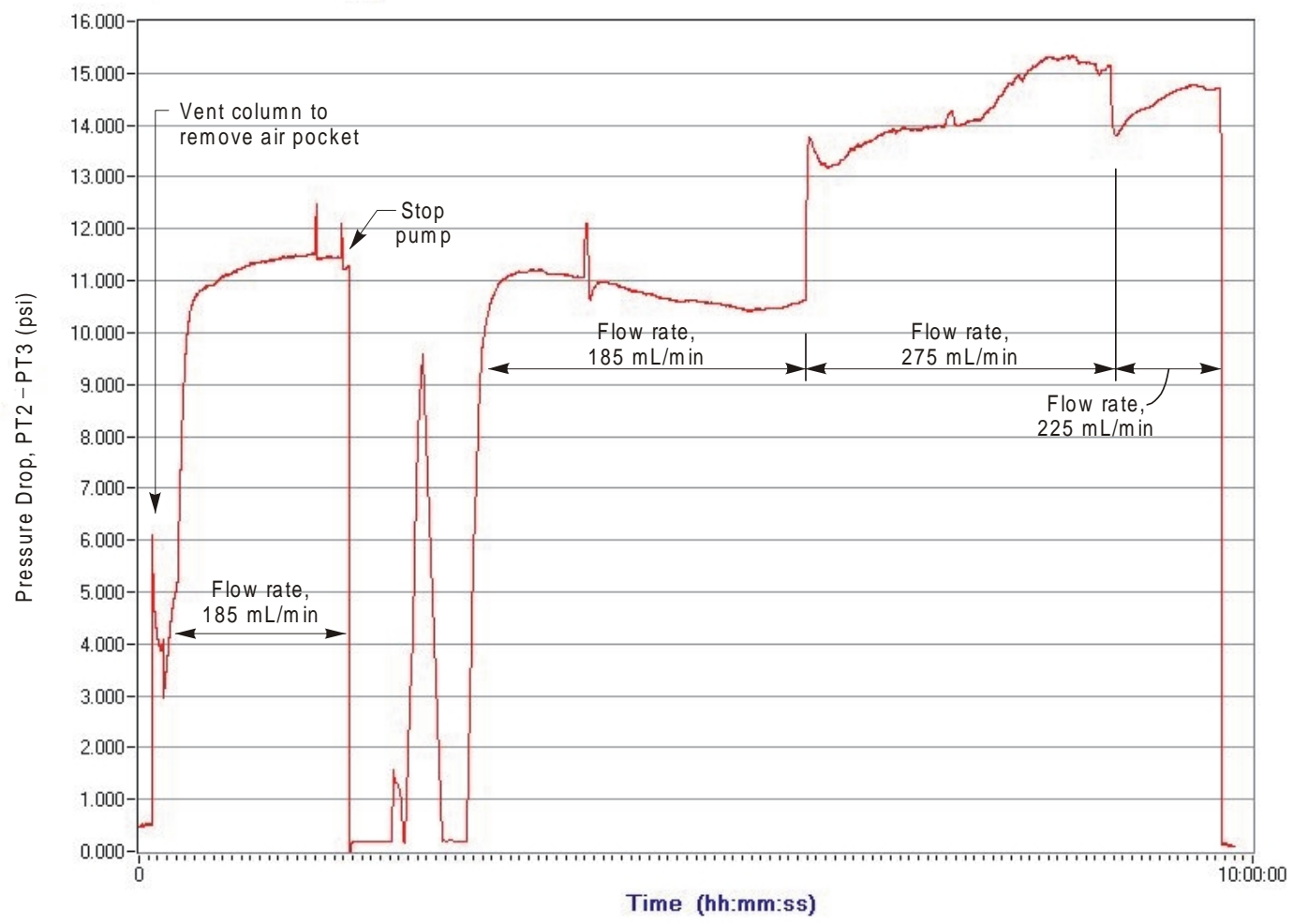

Fig. 4.2. Pressure drop across bed interface, test 1. PT2 = pressue above the bed; PT3 = pressure below the bed at $4 \mathrm{~m}$ from the bottom of the column.

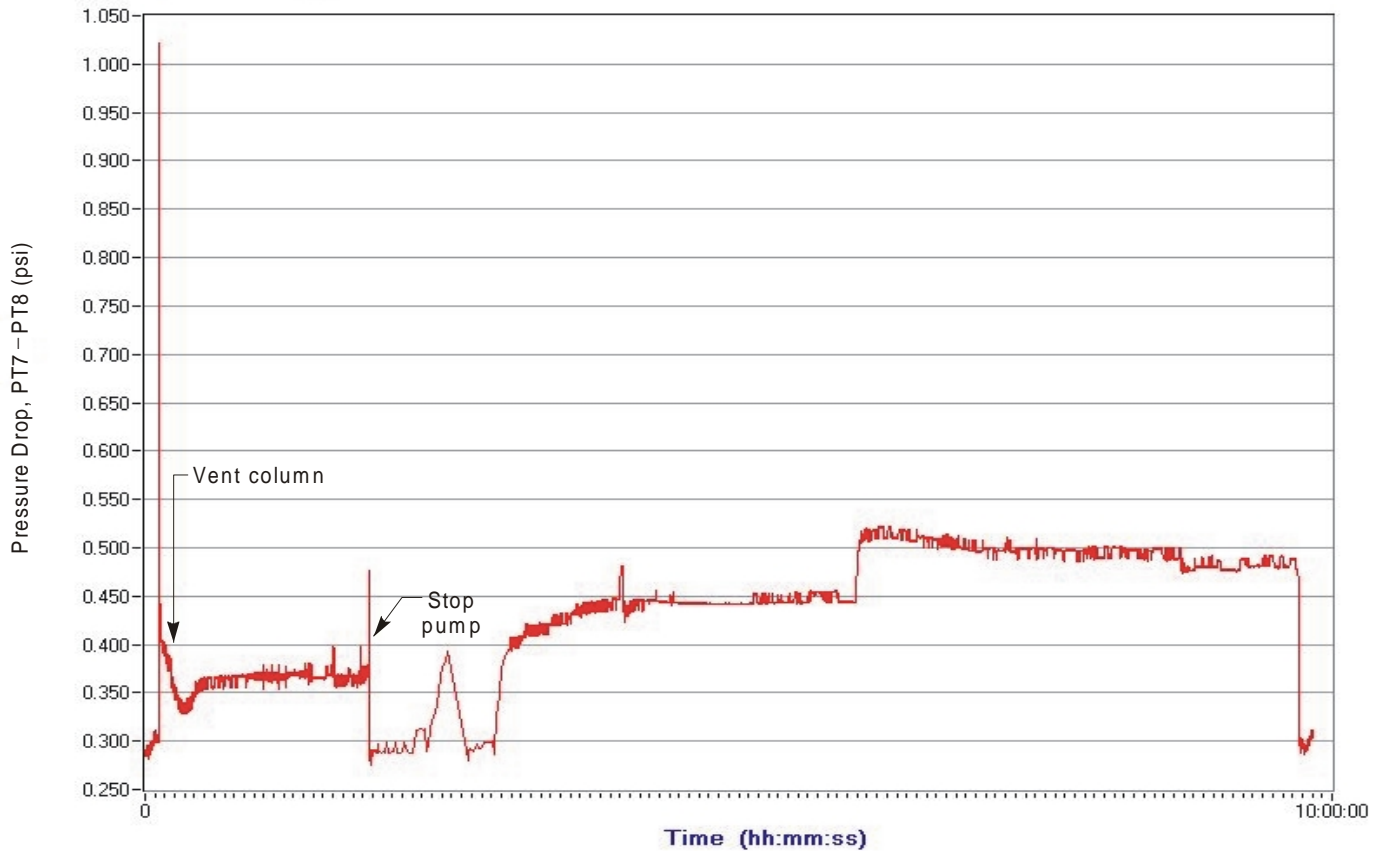

Fig. 4.3. Pressure drop across the Johnson screen, test 1 . PT7 $=$ pressure at the bottom of the column; PT8 = pressure downstream from the Johnson screen. 
discussion) that the material at the top of the bed included broken CST particles.

Figures 4.4 and 4.5 show a trend of increasing pressure drop across the bed and across the interface with time. However, the pressure drop at the startup of test 1 was lower than the pressure drop at the shutdown of the test. This drop may result from a slight upflow in the column upon shutdown that perturbed the top layer. The pressure drop across the Johnson screen was the same as in test 1 (Fig. 4.6).

\subsection{HYDRAULIC TEST 3: CONTINUATION AT $5 \mathrm{~cm} / \mathrm{min}$}

Hydraulic test 3 was a continuation of hydraulic test 2 conducted at a superficial velocity of $5 \mathrm{~cm} / \mathrm{min}$ (flow rate of $225 \mathrm{~mL} / \mathrm{min}$ ). After startup of this test, the desired feed rate was not obtained until several hours into the test, while the feed pump was being recalibrated. During this $12 \mathrm{~h}$ of operation the pressure drop across the bed and the interface increased with time (Figs. 4.7 and 4.8). The pressure drop across the Johnson screen again remained the same as in tests 1 and 2 (Fig. 4.9).

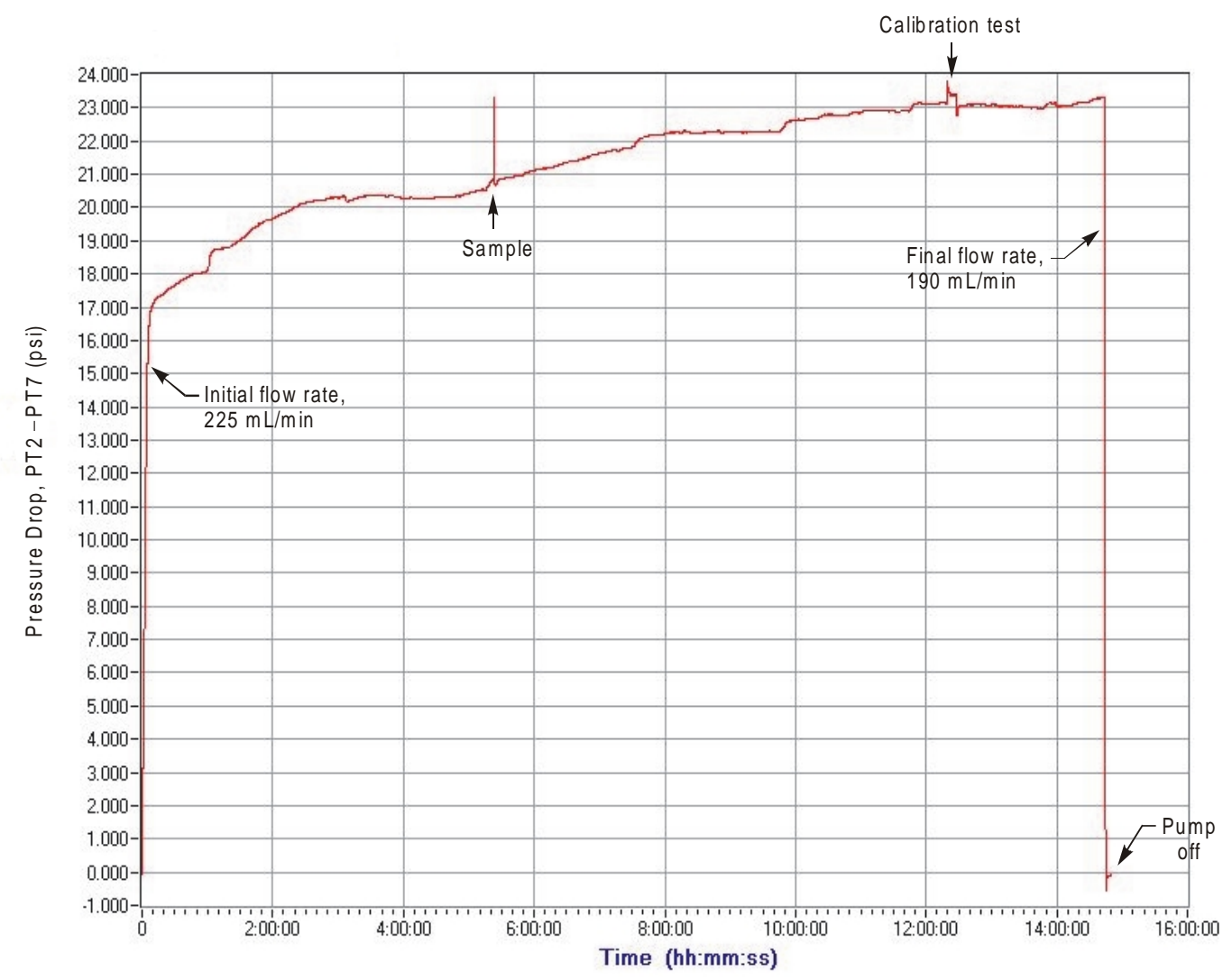

Fig. 4.4. Pressure drop in bed, test 2. PT2 = pressure above the bed; PT7 = pressure at the bottom of the column. 


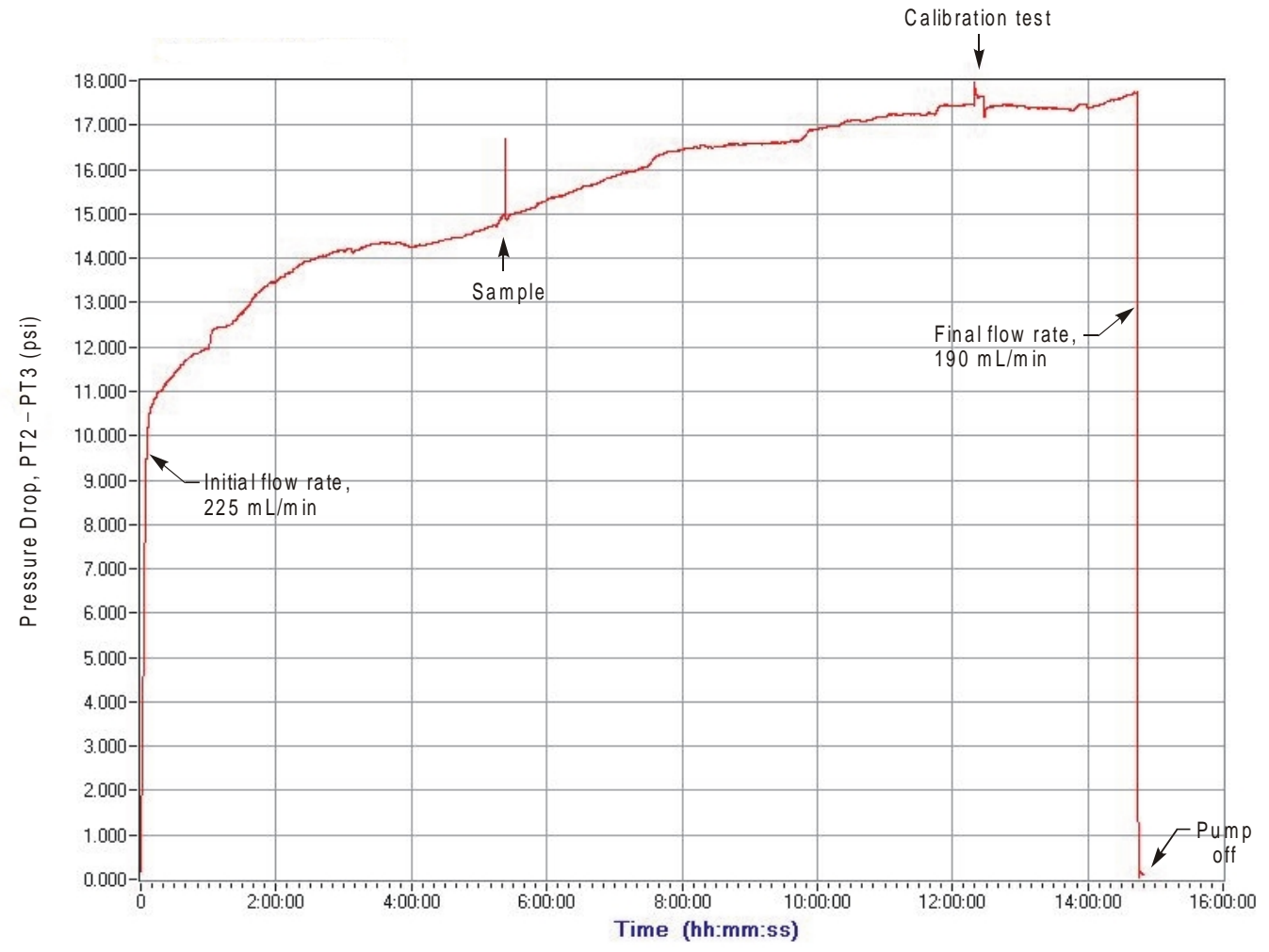

Fig. 4.5. Pressure drop across bed interface, test 2. PT2 $=$ pressure above the bed; PT3 = pressure below the bed at $4 \mathrm{~m}$ from the bottom of the column.

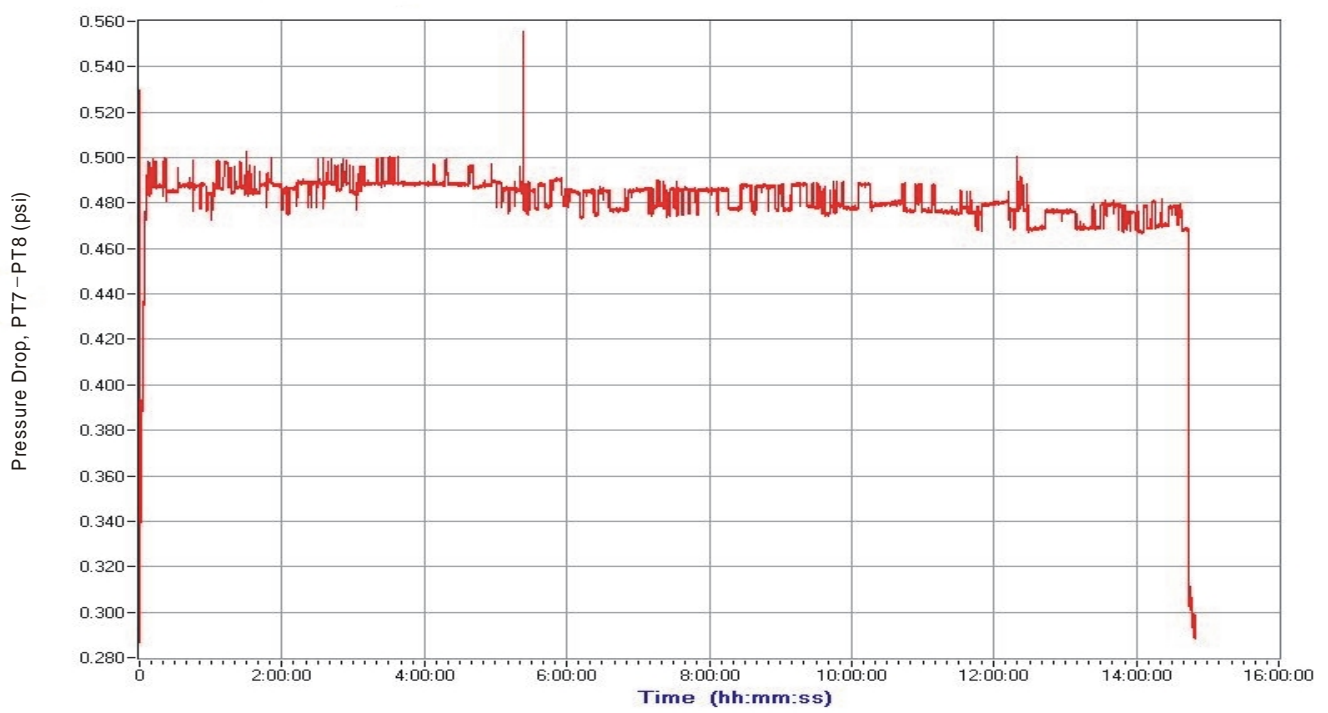

Fig. 4.6. Pressure drop across the Johnson screen, test 2. PT7 $=$ pressure at the bottom of the column; PT8 = pressure downstream from the Johnson screen. 


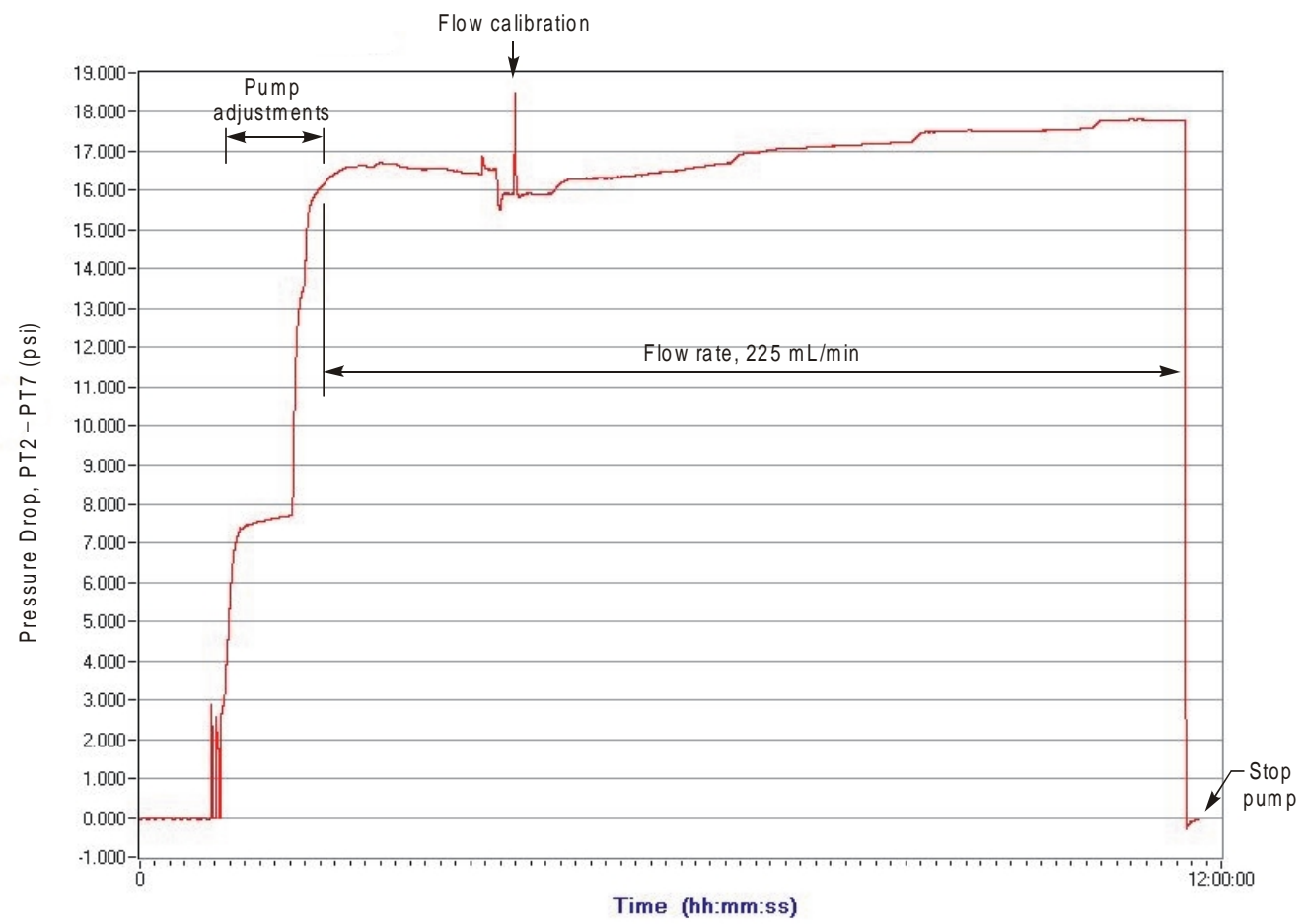

Fig. 4.7. Pressure drop in bed, test 3 . PT2 = pressure above the bed; PT7 = pressure at the bottom of the column.

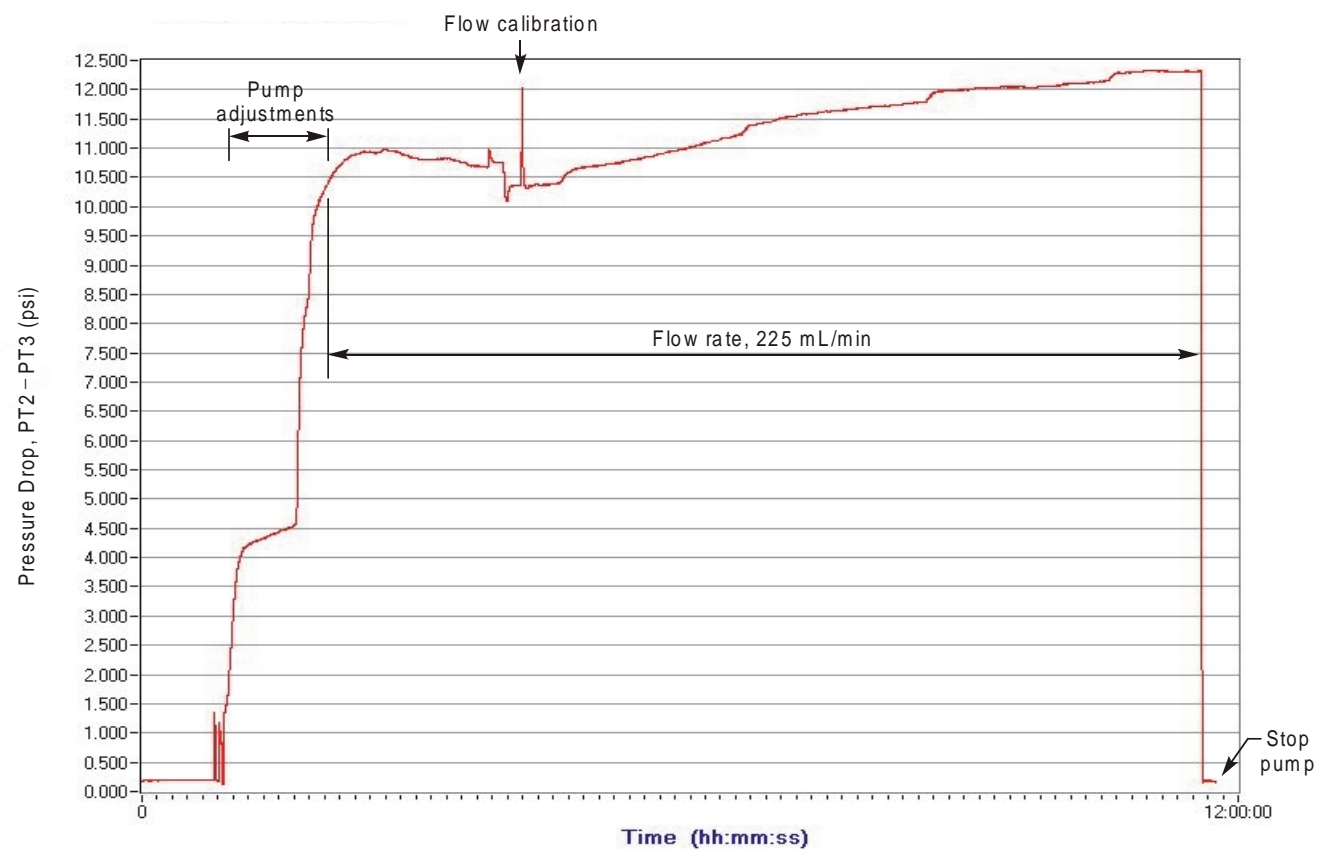

Fig. 4.8 Pressure drop across bed interface, test 3. PT2 $=$ pressure above the bed; PT3 = pressure below the bed at $4 \mathrm{~m}$ from the bottom of the column. 


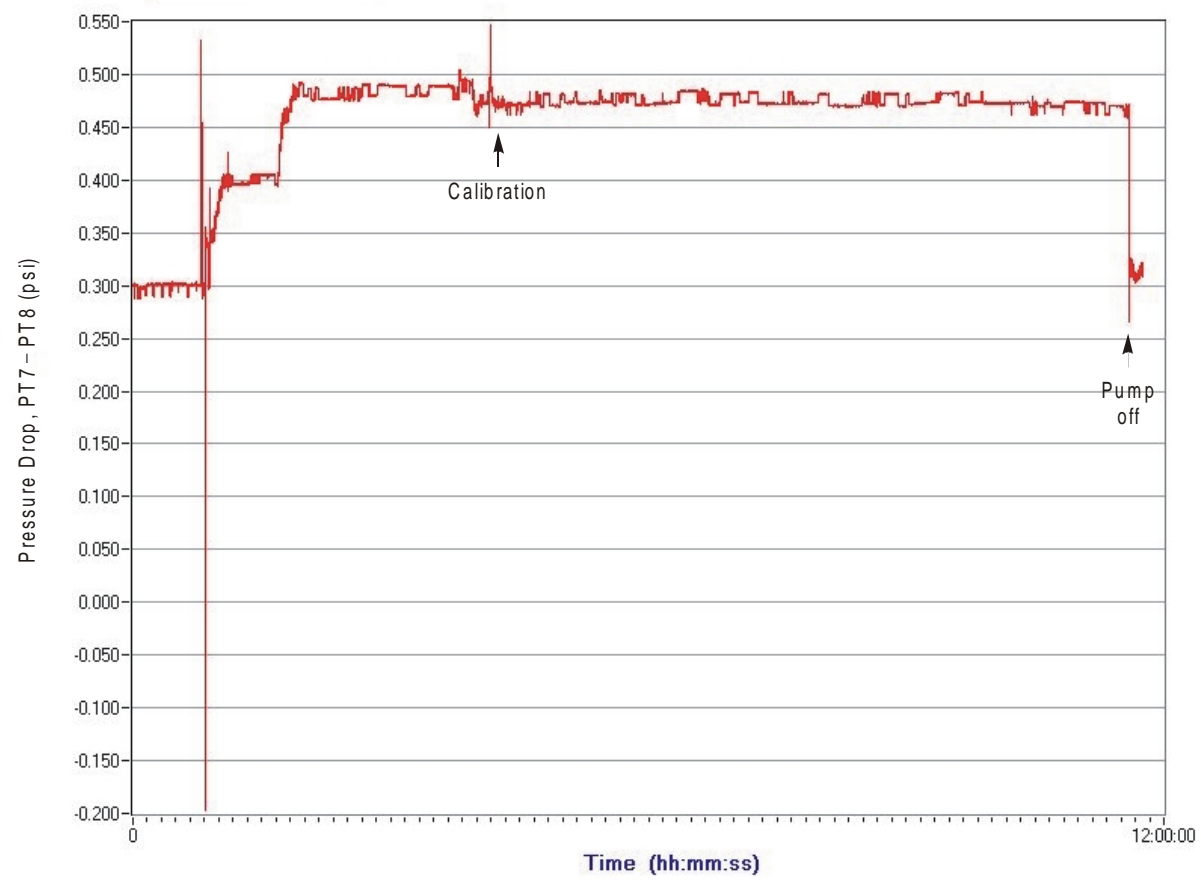

Fig. 4.9. Pressure drop across the Johnson screen, test 3 . PT7 $=$ pressure at the bottom of the column; PT8 = pressure downstream from the Johnson screen.

\subsection{HYDRAULIC TEST 4: CONTINUATION AT 5 cm/min}

In hydraulic test 4 , the column continued to operate at a superficial velocity of $5 \mathrm{~cm} / \mathrm{min}$ (flow rate of $225 \mathrm{~mL} / \mathrm{min}$ ). As seen in Fig. 4.10, the pressure drop across the column increased at a slower rate than it did during the previous three tests. This slower rate of increase may have been attributable to a stable layer of fines, broken particles, or slowing precipitate formation. A sample was collected from the top of the bed at the end of this test. The results from analysis of this material are presented in Sect. 7. The pressure drop across the interface continued to be a significant fraction $(\sim 60 \%)$ of the total pressure drop (Fig. 4.11). Also, as in previous startups, the initial pressure drop after startup was lower than the pressure drop upon shutdown of the previous test. The pressure drop across the Johnson screen again remained constant (Fig. 4.12). 


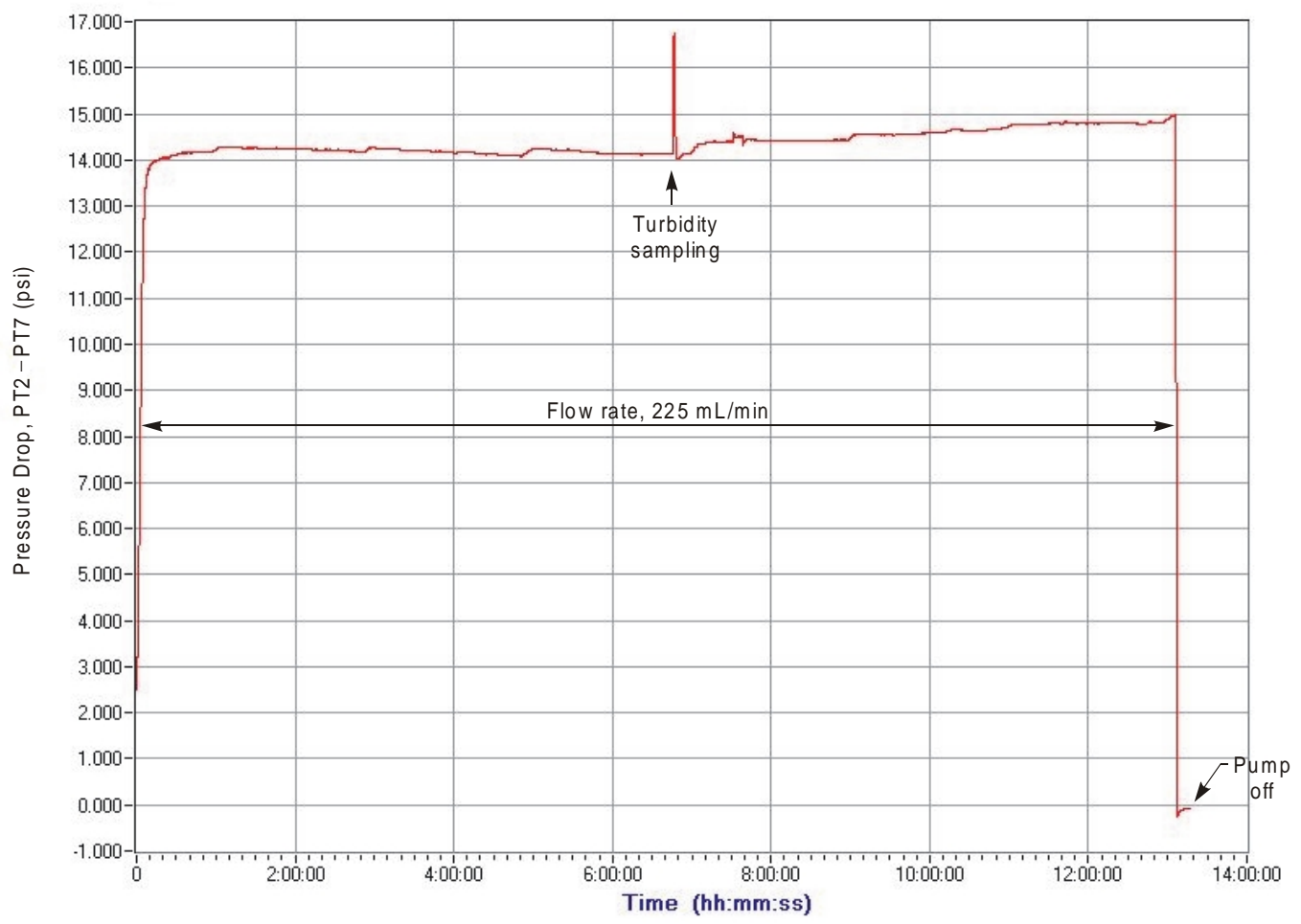

Fig. 4.10. Pressure drop in bed, test 4 . PT $2=$ pressure above the bed; PT7 $=$ pressure at the bottom of the column.

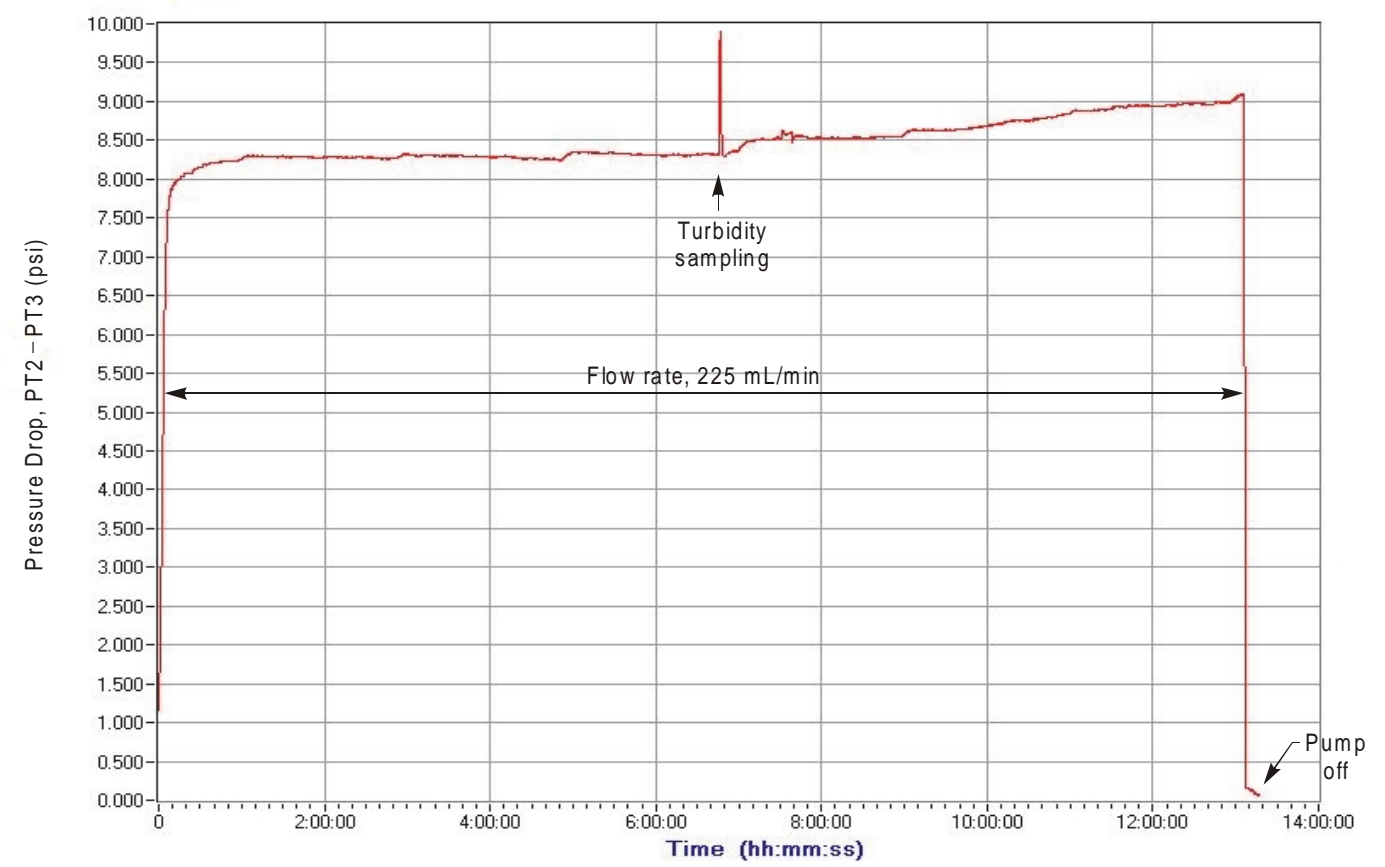

Fig. 4.11. Pressure drop in bed interface, test 4 . PT2 = pressure above the bed; PT3 = pressure below the bed at $4 \mathrm{~m}$ from the bottom of the column. 


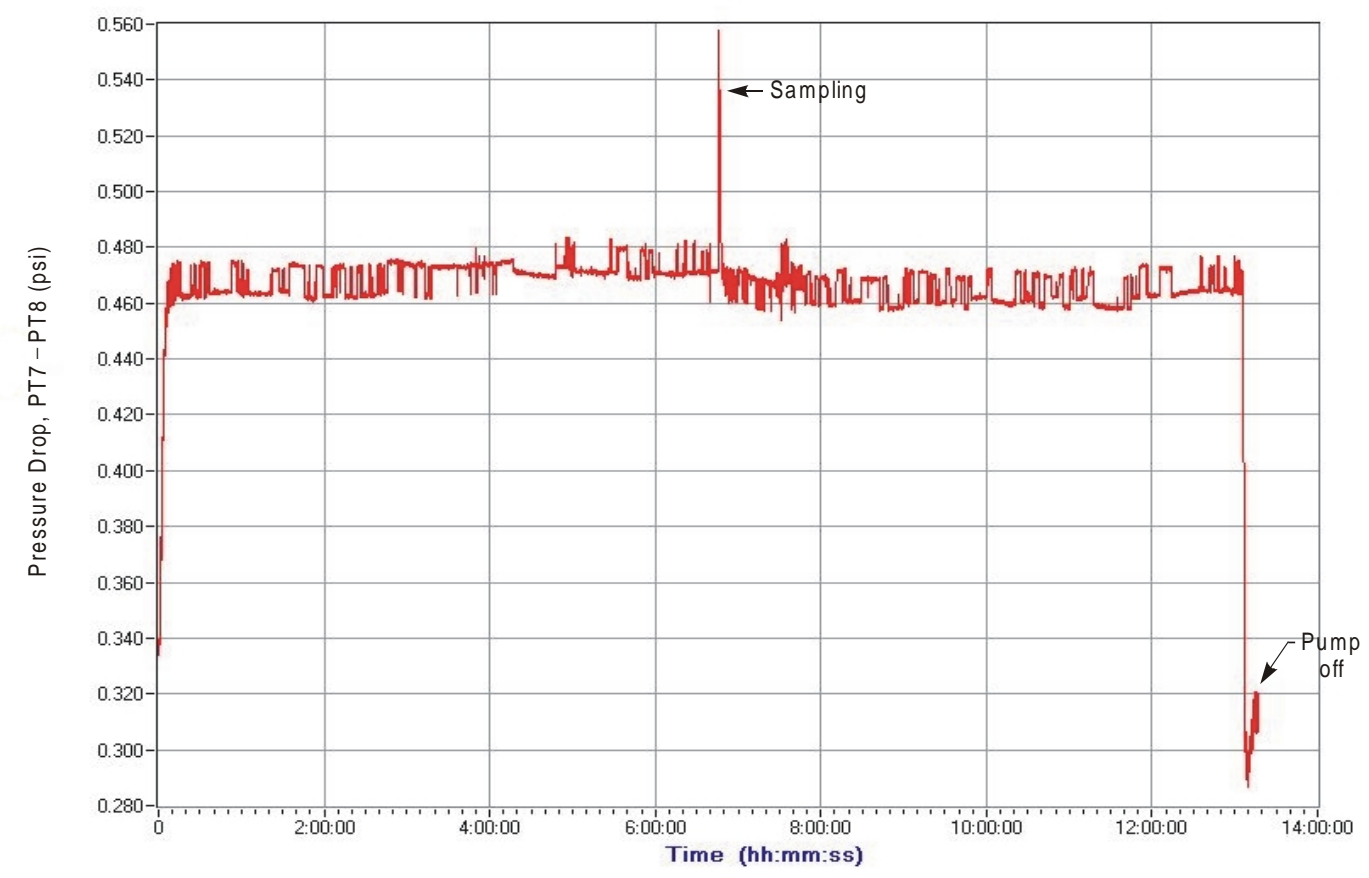

Fig. 4.12. Pressure drop across the Johnson screen, test 4. PT7 = pressure at the bottom of the column; PT8 = pressure downstream from the Johnson screen.

\subsection{HYDRAULIC TEST 5: BED EXPANSION}

Before conducting hydraulic test 5, a portion of the top of the bed containing the discolored layer and fines was vacuumed and the residue was sent for analysis. The results of this analysis are discussed in Sect. 7. CST fragments and some precipitates were found. The column was then operated at the nominal flow rate for $\sim 6 \mathrm{~h}$. (Note that the bed pressure drop has decreased from 14 psi at the end of test 4 to less than 9 psi after a part of the top of the bed was removed.) Removing just a part of the top layer of the bed reduced the bed resistance. The bed was then expanded and run for several more hours. [Note that the column and interface pressure drops are significantly less than they were in the previous four tests (Figs. 4.13 and 4.14).] When the bed was expanded, the visible cloud of fines appeared to have been redistributed in the bed. [Note also that the simulant-CST bed interface accounted for a smaller percentage of the total pressure drop $(\sim 30 \%)$.] Figure 4.15 shows that the pressure drop across the Johnson screen was about $0.5 \mathrm{psi}$ at the end of the test after bed expansion. 


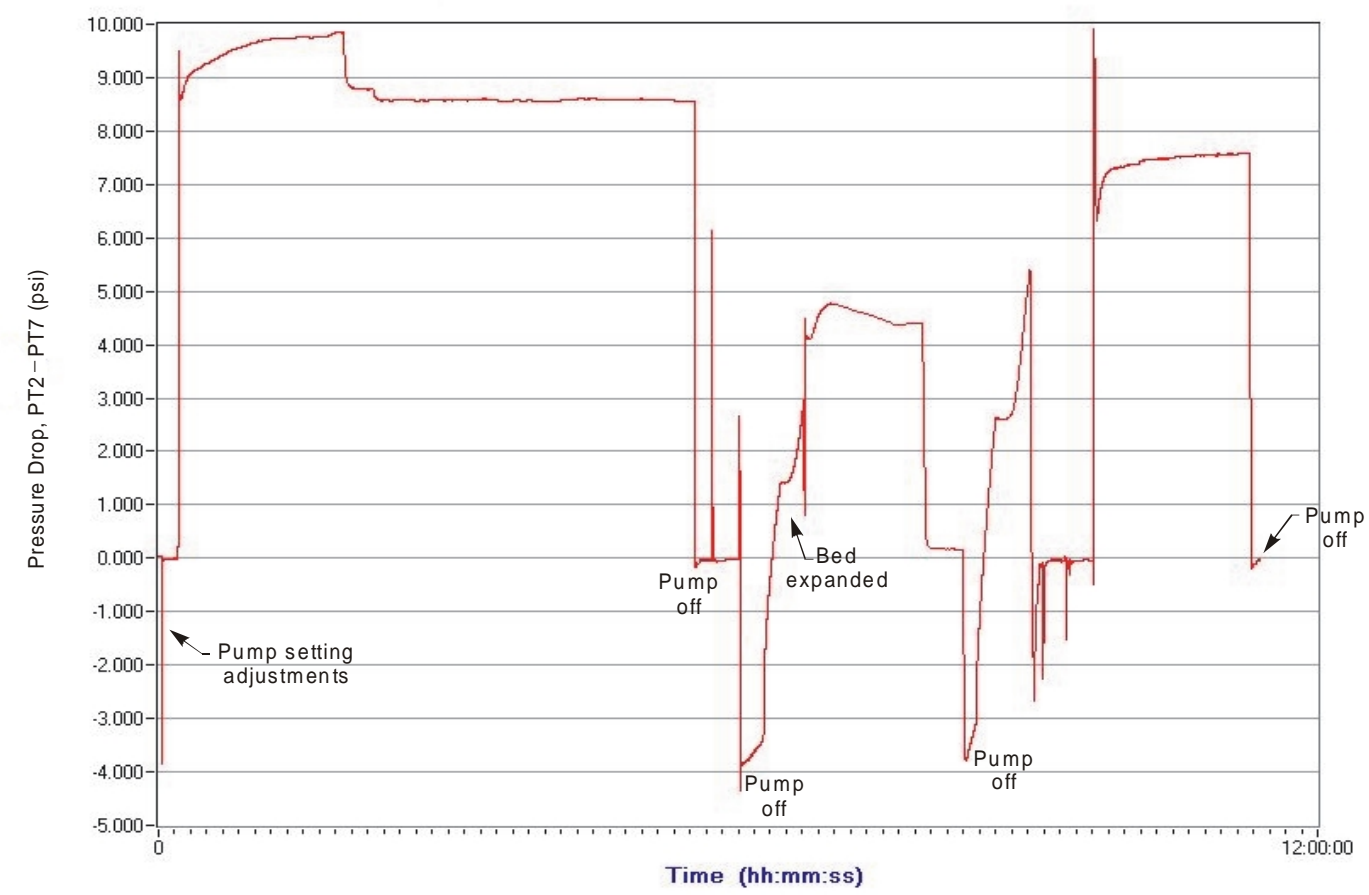

Fig. 4.13. Pressure drop in bed, test 5. PT 2 = pressure above the bed; PT7 = pressure at the bottom of the column.

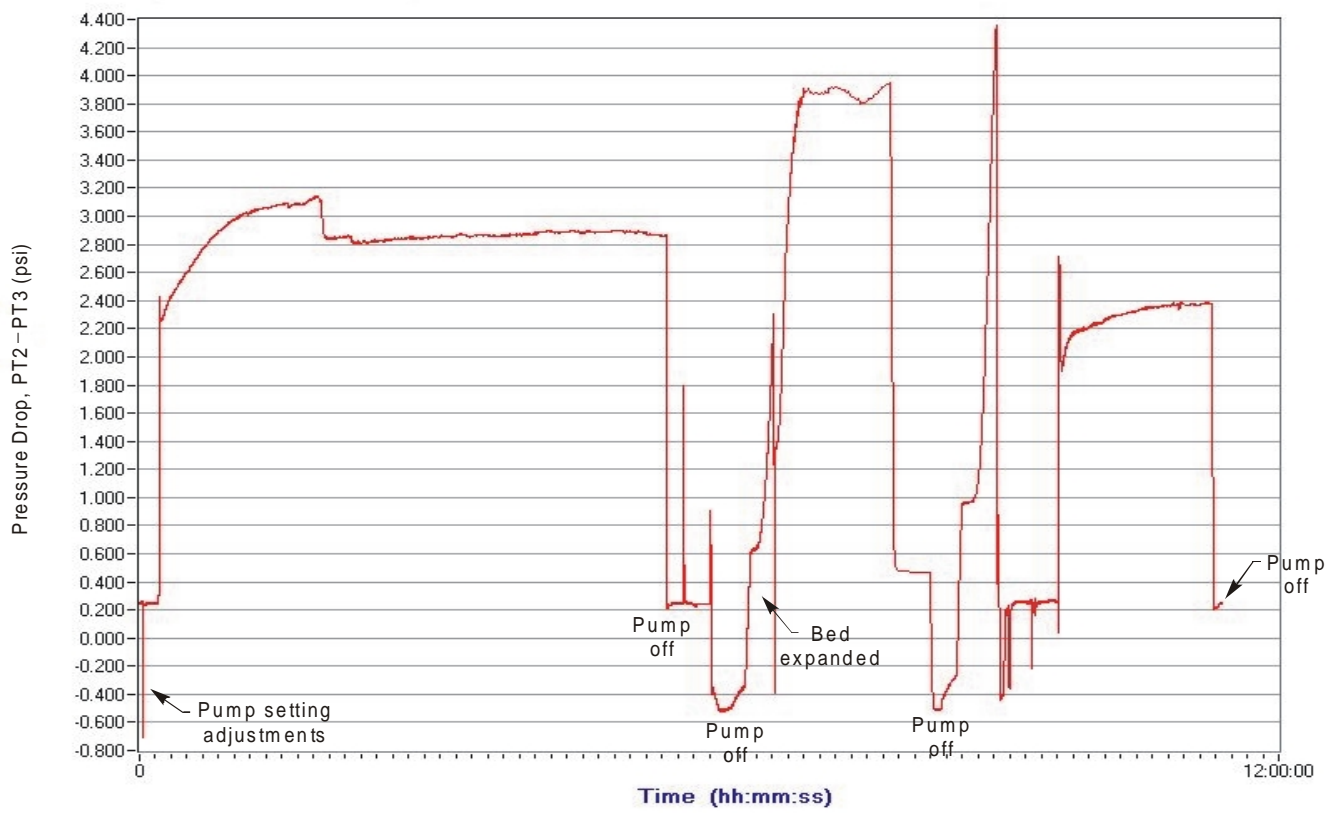

Fig. 4.14. Pressure drop across bed interface, test 5. PT2 $=$ pressure above the bed; PT3 = pressure below the bed at $4 \mathrm{~m}$ from the botom of the column. 


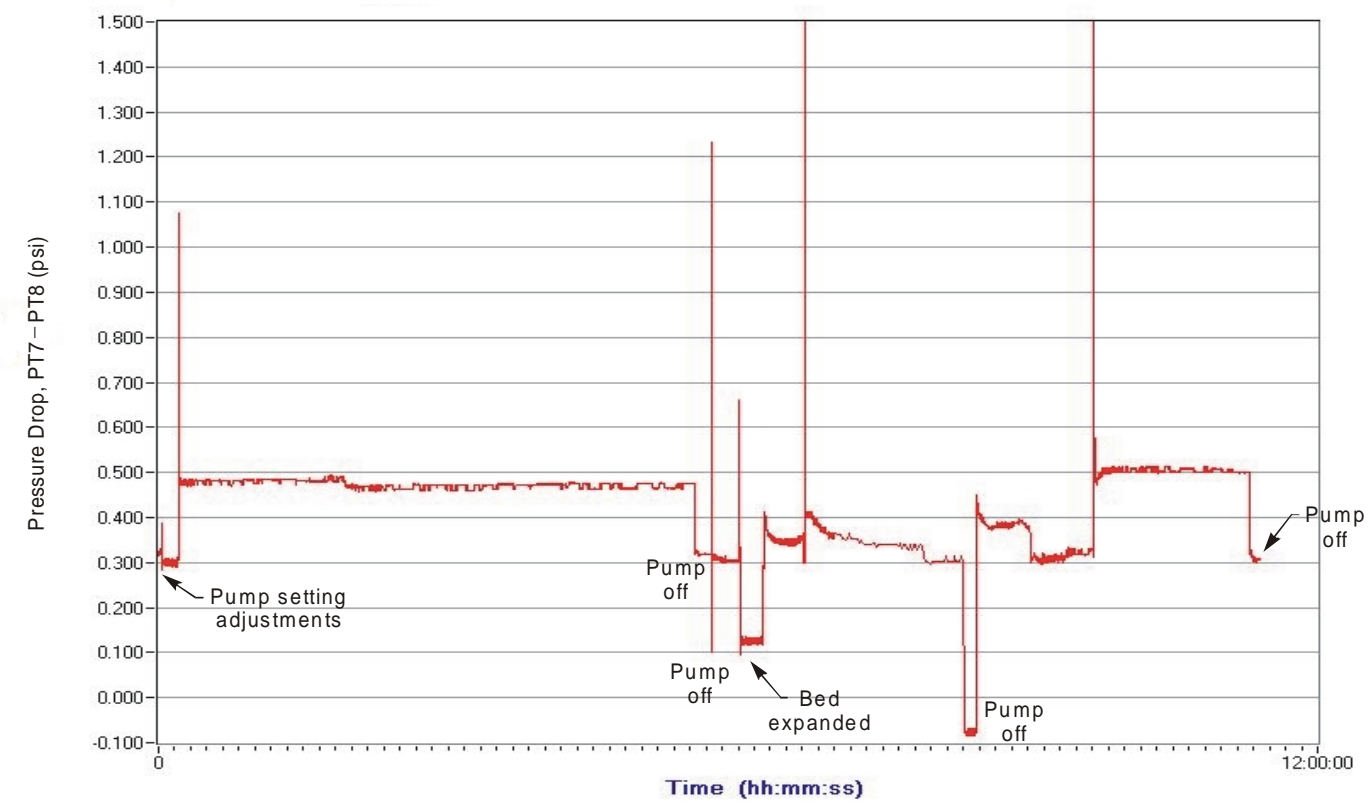

Fig. 4.15. Pressure drop across the Johnson screen, test 5. PT7 = pressure at the bottom of the column; PT8 = pressure downstream from the Johnson screen.

\subsection{HYDRAULIC TEST 6: FINAL TEST AFTER BED EXPANSION}

Hydraulic test 6 was a continuation of hydraulic test 5 , both of which were run under the same conditions. As shown in the Figs. 4.16 and 4.17, redistributing the layer at the top of the bed with fines by expanding the bed reduced the obstruction to the flow. This test continued to show the same pressure drops as the final portion of test 5 . The pressure drops remained constant throughout the entire test. The pressure drop across the Johnson screen appears to have increased slowly during the run (Fig. 4.18).

\subsection{EVALUATION OF HYDRAULIC TEST DATA}

During the first $48 \mathrm{~h}$ of startup and operation (hydraulic tests 1-4), pressure drops across the column gradually increased from 17 to $23 \mathrm{psig}$. The pressure drops at the liquid-CST interface accounted for the majority of the pressure drop across the column (60 to 70\%). The pressure drops across the remainder of the bed were relatively constant and varied from 0.35 to $0.45 \mathrm{psig} / \mathrm{ft}$. It is clear that the pressure drop across the liquid-CST interface was caused by the residual layer of fines and fragments of CST at the top of the column and the material in the discolored layer. After a portion of this material was removed and the bed was expanded, the pressure drops were lower and stabilized. The pressure drop across the Johnson screen remained constant throughout the six tests. At the nominal flow rate of $225 \mathrm{~mL} / \mathrm{min}$, the pressure drop ranged from 0.45 to $0.55 \mathrm{psig}$. 
The expected pressure drop across the column was calculated using the Blake-Kozeny equation: ${ }^{8}$

$\Delta p=150$ vo $L \mu(1-\varepsilon)^{2} / D p^{2} \varepsilon^{3} g$,

where

$v_{0}=0.0027 \mathrm{ft} / \mathrm{s}(5 \mathrm{~cm} / \mathrm{min})$,

$L=16 \mathrm{ft}$,

$\mu=0.00228 \mathrm{lb} /(\mathrm{ft} \cdot \mathrm{s})(3.4 \mathrm{cP})$,

$\varepsilon=0.43$,

$D_{p} \quad=382 \mu \mathrm{m}$

$G \quad=\quad 32.2 \mathrm{ft} / \mathrm{s}^{2}$.

The calculated pressure drop of 7.75 psi was in good agreement with the measured 7.4-psig pressure drop in hydraulic test 6.

In summary, material at the top of the bed provided the major flow resistance in the system. The bed packed evenly, and no channeling was detected. The pressure drop across the rest of the bed was relatively constant. Also, the pressure drop across the the bottom of the column; PT8 = pressure downstream from the Johnson screen. Johnson screen did not increase, indicating no accumulation on the screen. If the bed can be loaded and the fines removed from the top of the column, the pressure drop across the column at a given flow rate should be predictable.

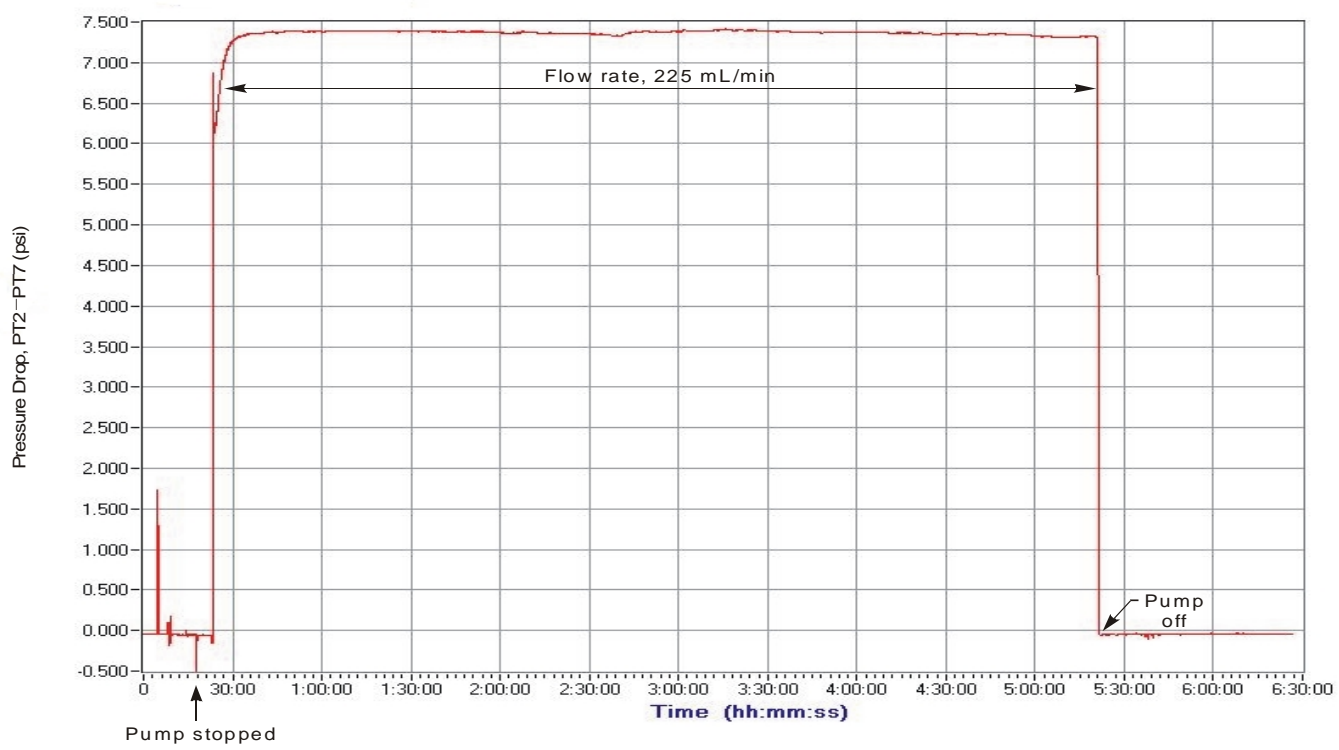

Fig. 4.16. Pressure drop in bed, test 6. PT $2=$ pressure above the bed; PT7 $=$ pressure at the bottom of the column. 


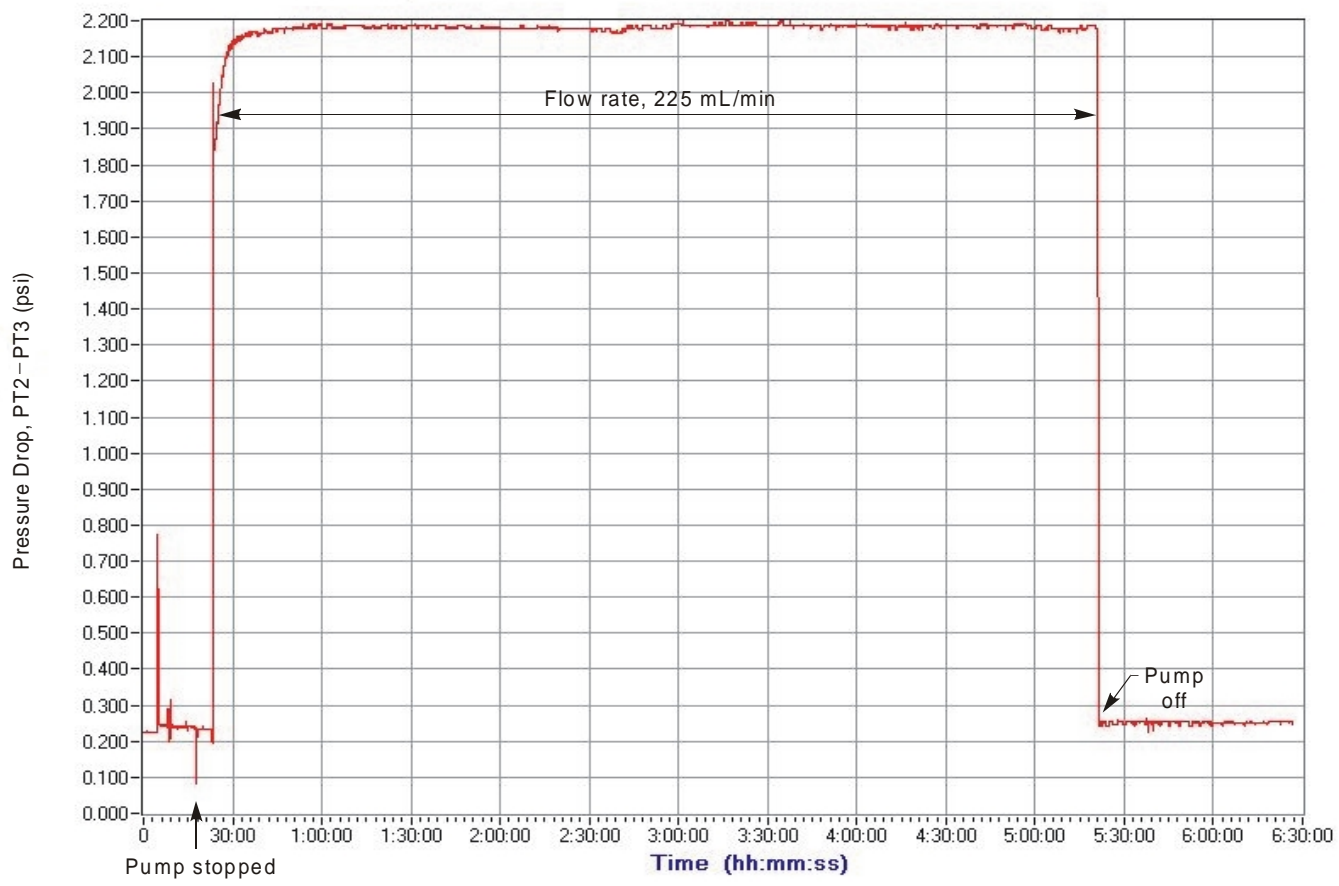

Fig. 4.17. Pressure drop across bed interface, test 6. PT2 $=$ pressure above the bed; PT3 = pressure below the bed at $4 \mathrm{~m}$ from the bottom of the column.

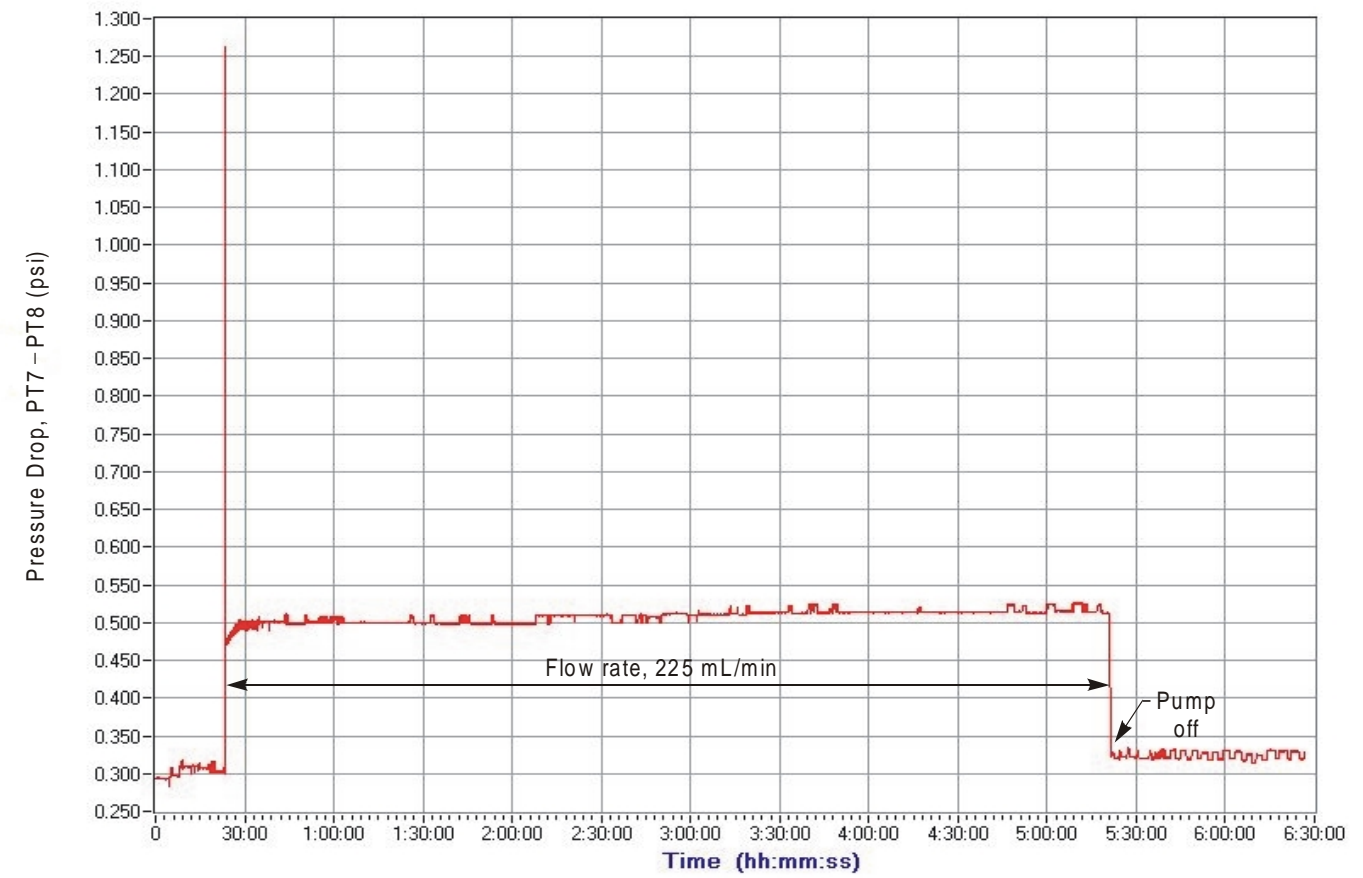

Fig. 4.18. Pressure drop across the Johnson screen, test 6. PT7 = pressure at the bottom of the column; PT8 = pressure downstream from the Johnson screen. 


\section{LABORATORY GAS TESTS}

Before the gas-behavior tests in the test column could be conducted, a method to simulate radiolytic gas generation needed to be developed. In a full-scale column with radioactive feed, gases would be generated by the radiation from ${ }^{137} \mathrm{Cs}$ that is loaded on the CST. Thus, as the cesium wave front moves down through the column, a corresponding gas-generation wave front moves with it. The gas-generation rate in a fully loaded 5-ft-diam, 16-ft-long column was estimated to be $33 \mathrm{~L} / \mathrm{h},{ }^{5}$ which corresponds to $82 \mathrm{~cm}^{3} / \mathrm{h}$ in the 3 -in-diam test column. A technique that generates gas within the CST bed at the required rate was needed.

Dissolved gas release by depressurization, dissolved gas release by heating, electrolysis, direct gas injection, and hydrogen peroxide decomposition to oxygen were considered. Hydrogen peroxide decomposition was selected for development because it appeared to offer the closest analog to homogeneous radiolytic gas generation and implementation appeared to be feasible within the schedule.

To be feasible as a method to mimic actual gas generation, the hydrogen peroxide decomposition reaction had to have several characteristics. The hydrogen peroxide reaction rate in the presence of CST had to be capable of producing the desired $82 \mathrm{~cm}^{3} / \mathrm{h}$, and the quantity of hydrogen peroxide to be added needed to be low enough that it did not overdilute the simulant.

The scoping tests conducted to develop the hydrogen peroxide decomposition method are summarized in Sects. 5.1-5.3. Several laboratory batch-reactor tests and a small-column test were conducted to obtain the data concerning the reaction rate of the hydrogen peroxide decomposition needed to plan the tall-column gas-behavior test. Adsorption of peroxide on the CST and other interactions of hydrogen peroxide with CST were investigated.

\subsection{BATCH TESTS OF HYDROGEN PEROXIDE DECOMPOSITION}

An initial set of tests was conducted to determine the decomposition rate of peroxide in caustic solution, in simulated waste, and in a mixture of simulated waste and IONSIV® IE-911. In these initial tests, reactants (peroxide, $\mathrm{CST}, \mathrm{NaOH}$, and/or simulant) were placed in a reaction flask (flask A); water was placed in a second flask (flask B). Rubber stoppers and tubing were connected so that gas generated in flask A passed into the void space above the water in flask B. As gas transferred into flask B, water in this flask was displaced through a tube into a graduated cylinder. The volume of displaced water was measured periodically, and the time and volume were recorded. In the first test with this two-flask system, $150 \mathrm{~mL}$ of $1 M \mathrm{NaOH}$ was mixed with $150 \mathrm{~mL}$ of $3 \mathrm{wt} \%$ hydrogen peroxide. Gas generation was measured over $28 \mathrm{~h}$. The longterm gas-generation rate was $4 \mathrm{~mL} / \mathrm{h}$. In the second test, $90 \mathrm{~mL}$ of $2 M \mathrm{NaOH}$ and $30 \mathrm{~mL}$ of $3 \mathrm{wt} \%$ hydrogen peroxide were added to $250 \mathrm{~mL}$ of IONSIV® IE-911 ( $25 \mathrm{wt} \%$ water). The initial gas-generation rate was $48 \mathrm{~mL} / \mathrm{h}$. However, the gas-generation rate decreased significantly after the first $1.5 \mathrm{~h}$. In the third test with this system, $30 \mathrm{~mL}$ of $3 \mathrm{wt} \%$ hydrogen peroxide was added to $75 \mathrm{~mL}$ of IONSIV® IE-911. The initial gas-generation rate was much higher than in the first two tests, and the reaction was essentially complete within $1.5 \mathrm{~h}$. The 
results from this test apparatus indicated that the hydrogen peroxide decomposition is relatively slow in $\mathrm{NaOH}$ and that CST serves as a catalyst for the decomposition reaction. However, the oxygen yield obtained was lower than expected. Since titanium stabilizes hydrogen peroxide, it was speculated that CST serves to adsorb and stabilize hydrogen peroxide.

A test matrix was designed to quantify the catalytic and adsorption phenomena. Hydrogen peroxide concentration and simulant-to-CST ratio were varied in these tests.

The next series of gas-generation tests was performed with a flask and manometer arrangement, as shown in Fig. 5.1. After the samples were transferred into the flask, it was placed in an Aquatherm $^{\mathrm{TM}}$ water bath shaker. The samples were shaken at $100 \mathrm{rpm}$. The early tests in this series were unsuccessful because of small leaks in the system. After the leaks were sealed, several tests at ambient temperature were conducted in 250 -mL flasks. The amounts of nitritefree simulant of the SRS average supernatant, CST, and peroxide used in these latter gasgeneration tests are listed in Table 5.1.

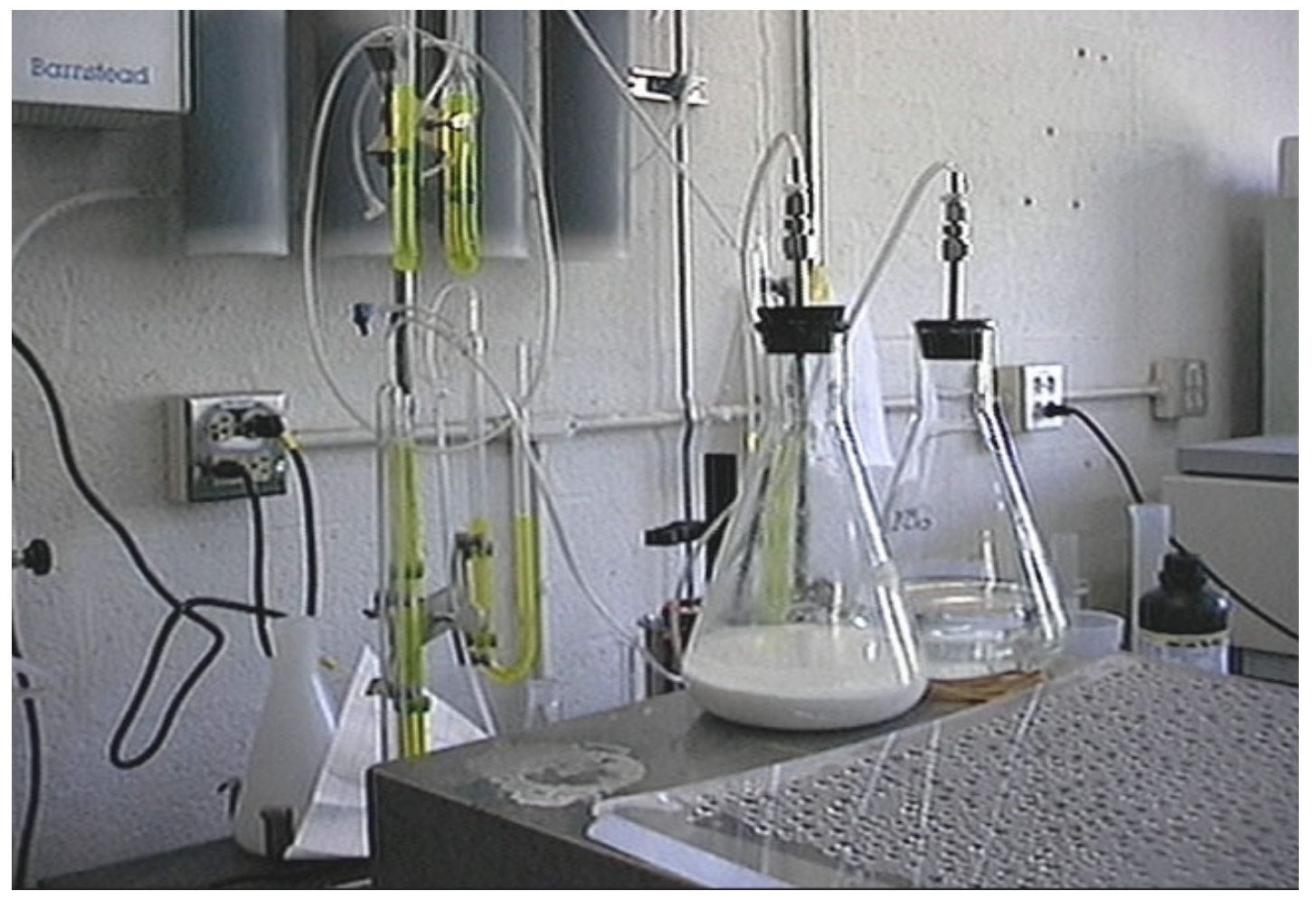

Fig. 5.1. A pair of reaction flasks (right) and manometers (left) used to measure gas generation by hydrogen peroxide decomposition. One reaction flask and one manometer were used for each test. 
Table 5.1. CST, nitrite-free simulant, and peroxide used in the batch gas-generation tests

\begin{tabular}{ccccc}
\hline Test number & $\begin{array}{c}\text { Weight of } \\
\text { CST }(\mathrm{g})\end{array}$ & $\begin{array}{c}\text { Weight of } \\
\text { simulant }(\mathrm{g})\end{array}$ & $\begin{array}{c}\text { Wt \% of } \\
\text { peroxide }\end{array}$ & $\begin{array}{c}\text { Ratio of liquid to } \\
\text { CST vol. }\end{array}$ \\
\hline 8 & 149.96 & 51.93 & 1.5 & $1: 1$ \\
9 & 150.24 & 54.43 & 0.7 & $1: 1$ \\
10 & 150.00 & 53.43 & 1.0 & $1: 1$ \\
11 & 150.00 & 51.89 & 1.5 & $1: 1$ \\
12 & 75.00 & 72.36 & 0.7 & $2: 1$ \\
13 & 75.00 & 207.90 & 0.7 & $5: 1$ \\
14 & 75.00 & 207.90 & 0.7 & $5: 1$ \\
15 & 700.00 & 693.5 & 0.07 & $2: 1$ \\
\hline
\end{tabular}

Peroxide measurements were also performed on small aliquots from the batch tests. Typically, a 10-mL sample of test solution was acidified with concentrated sulfuric acid. The solution was titrated with 0.05 or $0.005 \mathrm{~N}$ potassium permanganate until a faint pink color persisted for $30 \mathrm{~s}$. The initial tests indicated that the nitrite in the original SRS simulant was also oxidized by permanganate. Unfortunately, this additional reaction increased the apparent peroxide concentration. Because of the high levels of nitrite in the SRS simulant, all further tests were performed with nitrite-free simulant. The half-life of hydrogen peroxide in nitrite-free simulant without CST was determined to be about $20 \mathrm{~h}$. Thus, decomposition in the simulant is much slower than in the presence of IONSIV® IE-911.

As shown in Table 5.1, the peroxide concentration and liquid-to-CST ratio were systematically varied. The results are presented in Fig. 5.2, with the gas-generation results converted into cubic centimeters of gas per hour per kilogram of CST.

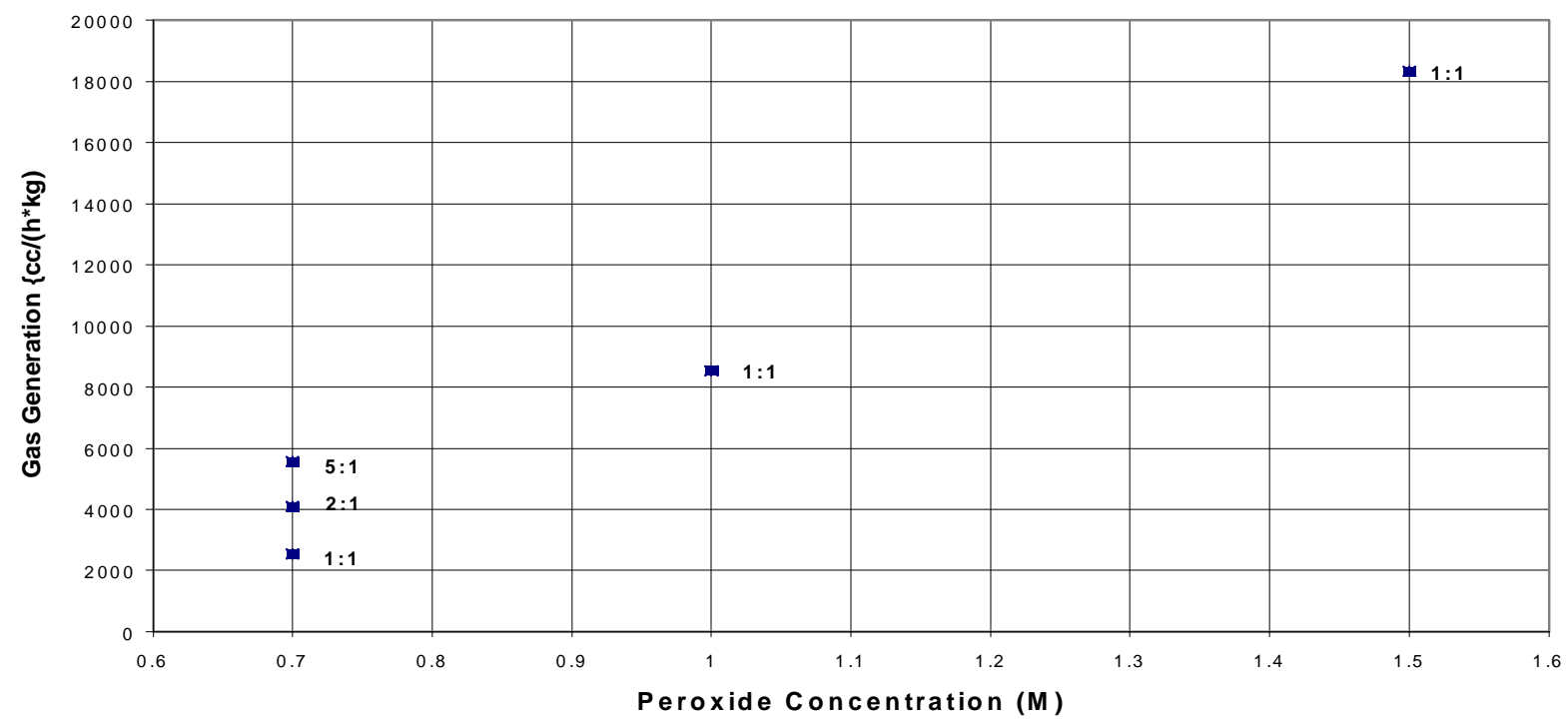

Fig. 5.2. Initial gas generation as a function of peroxide concentration and liquid-toCST ratio. 
Gas generation increased as the initial peroxide concentration and the liquid-to-CST ratio increased. Although IONSIV® IE-911 apparently catalyzes the decomposition reaction, only a fraction of the theoretical yield was obtained in these tests. This lower yield resulted from the adsorption of hydrogen peroxide on the IONSIV® IE-911.

\subsection{HYDROGEN PEROXIDE ISOTHERM}

After observing that hydrogen peroxide adsorption was significant, an isotherm for hydrogen peroxide adsorption onto CST was also determined. Known amounts of hydrogen peroxide, nitrite-free simulant, and CST were combined in centrifuge tubes and mixed for $24 \mathrm{~h}$. Potassium permanganate was then used to determine the peroxide concentration. The peroxide that was no longer in solution was assumed to be adsorbed onto the CST. The results of these tests are presented on Fig. 5.3. This information was used to determine the amount of hydrogen peroxide adsorbed and the time required to load the column with peroxide. However, the peroxide adsorption isotherm must be corrected for the portion of peroxide that reacted to form oxygen. Therefore, experiments that evaluated peroxide concentration and gas generation under the same experimental conditions were required. The test labeled "CST-Gas \#13" focused on the gasgeneration data, while the peroxide concentration was determined during CST-Gas \#14. The combined results of these experiments are displayed in Fig. 5.4. The adsorption curve was determined by difference. The peroxide lost to gas generation and that left in solution were subtracted from the initial amount of peroxide added. The results indicate that peroxide initially disappears by absorption, while decomposition becomes dominant at longer times.

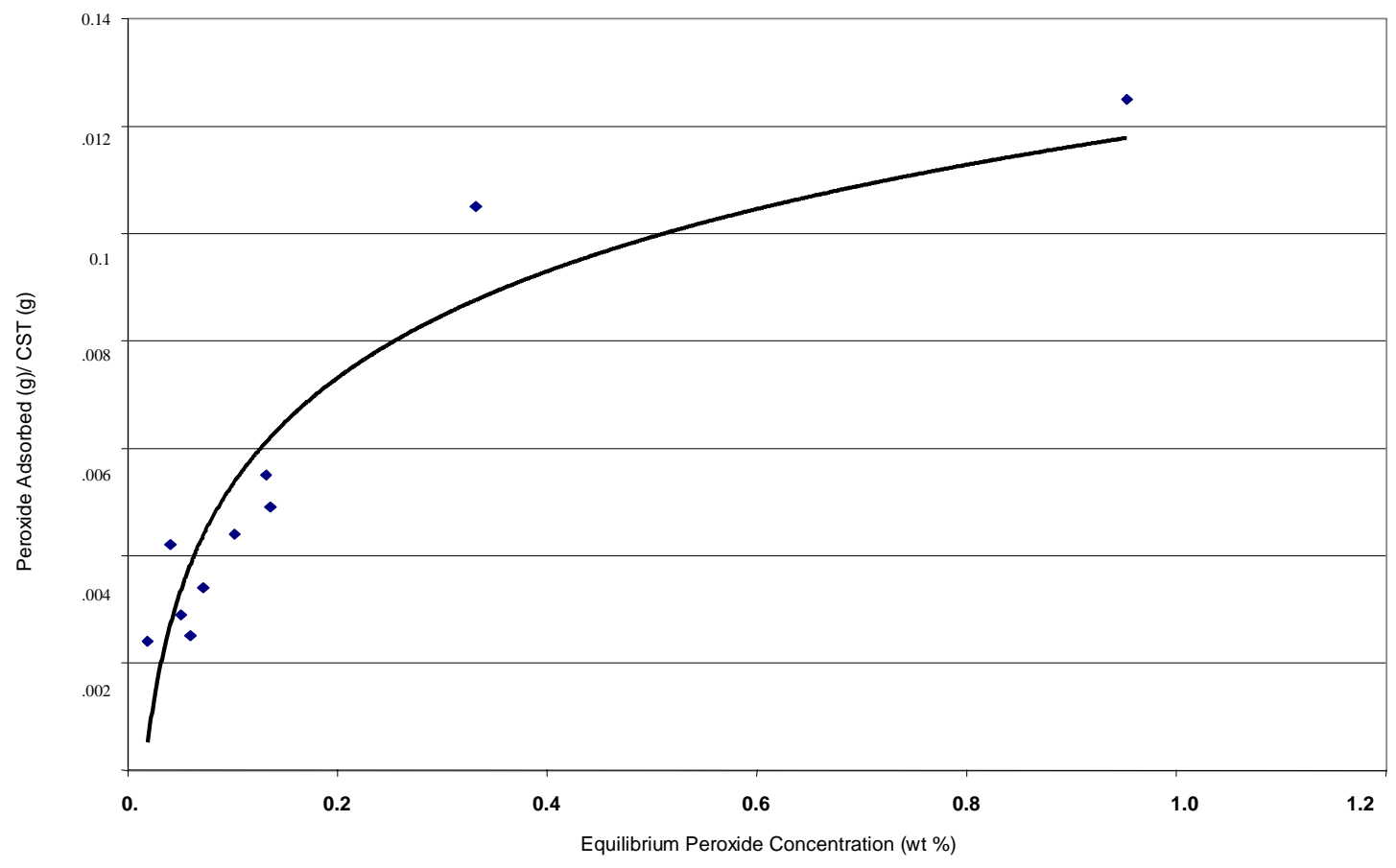

Fig. 5.3. Peroxide adsorption isotherm. 


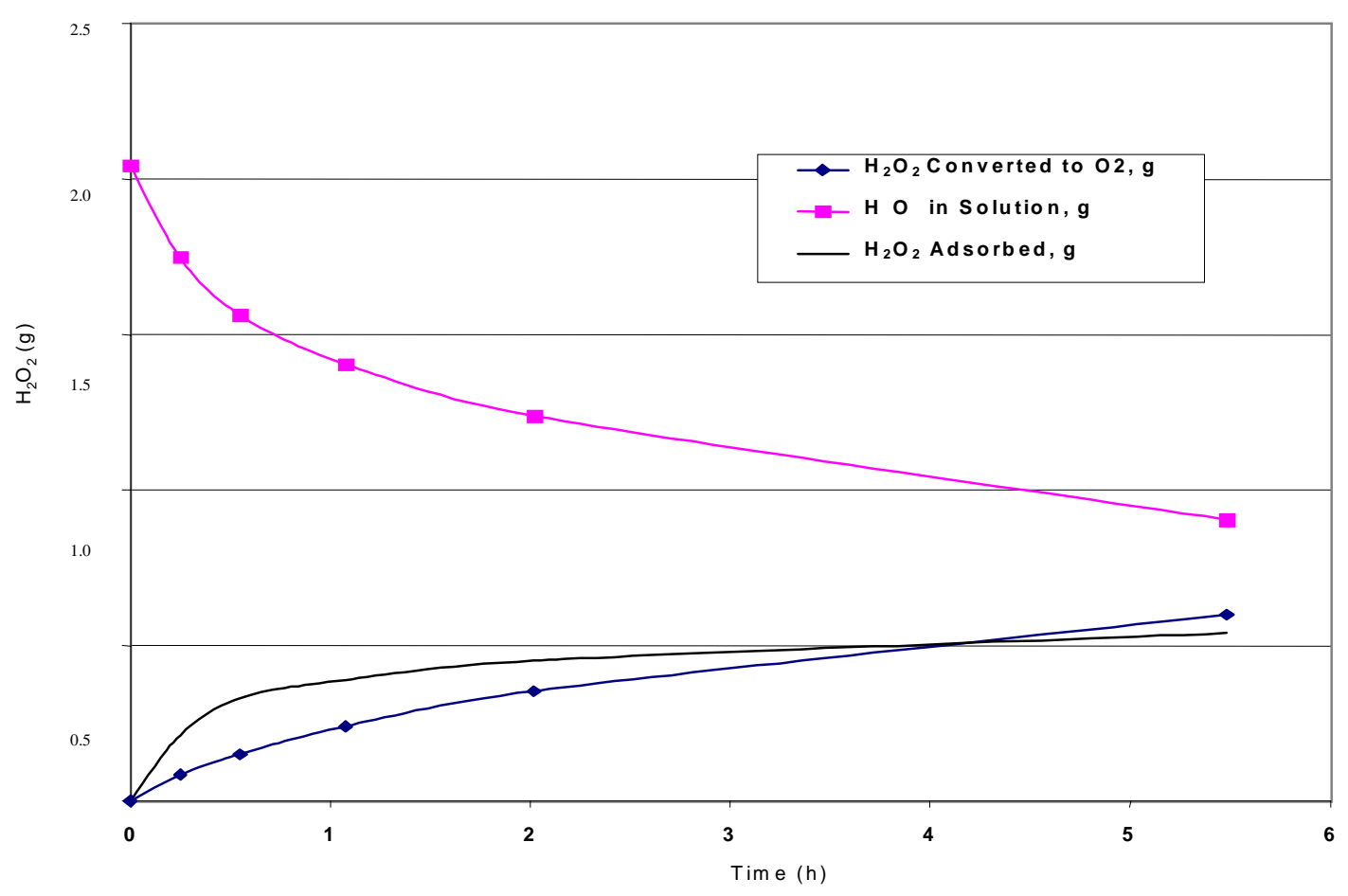

Fig. 5.4. Decomposition and adsorption of peroxide as a function of time.

\subsection{SMALL-COLUMN TESTS}

A small-column test was conducted to validate the peroxide decomposition rates obtained from the batch-reactor data and to estimate the hydrogen peroxide loading time on the CST. A small test apparatus was assembled from a 2-in-diam, 2-ft-long glass column, a MasterFlex ${ }^{\mathrm{TM}}$ feed pump, a polyethylene feed tank, and a disengaging tube to measure gas volume in the effluent. A bed of $1050 \mathrm{~g}$ of CST ( $24 \mathrm{wt} \%$ moisture) was added to the column to a height of $47 \mathrm{~cm}$. Peroxide was added to the feed tank periodically to maintain the peroxide concentration near the desired $0.0125 \mathrm{wt} \%$ concentration. A hydrogen peroxide concentration of $0.0125 \mathrm{wt} \%$ was selected for the small-column test based on the results from the batch tests. Nitrite-free simulant was fed to the top of the column at a flow rate of $166 \mathrm{~mL} / \mathrm{min}$ (a superficial velocity of $8.2 \mathrm{~cm} / \mathrm{min}$, which is twice the nominal velocity of the tall column). Gas generation started after $3.25 \mathrm{~h}$, compared with an expected $2 \mathrm{~h}$ based on the flow rate, hydrogen peroxide isotherm, and concentration. The longer breakthrough time resulted because the $\mathrm{H}_{2} \mathrm{O}_{2}$ concentration in the feed was less than desired part of the time since we used off-line analyses and adjusted the content for these values. Feed tank and column effluent samples were collected and analyzed by permanganate titration to determine peroxide concentration. Peroxide was added to the feed tank after analytical results were obtained, and because of this delay, hydrogen peroxide additions were not always made in time to keep the concentration at the desired level. Gas-generation rates were, however, in the desired range of $\sim 4 \mathrm{~cm}^{3} \cdot \mathrm{h}^{-1} \cdot \mathrm{kg}^{-1} \mathrm{CST}$ at a feed concentration of $\sim 0.003 \mathrm{wt} \%$ hydrogen peroxide. The rate constant for the decomposition reaction was estimated to be $21.9 \mathrm{~h}^{-1}$ The quantity of hydrogen peroxide adsorbed agreed well with the adsorption isotherm predictions. 


\section{COLUMN GAS TEST}

The gas test was conducted to determine the extent of accumulation of radiolytic gases and the means of gas release from the ion-exchange bed. The target gas-generation rate was $82 \mathrm{~cm}^{3} / \mathrm{h}$, based on the maximum expected gas generation in an actual system with average SRS supernatant. However, a gas-generation range of 40 to $320 \mathrm{~cm}^{3} / \mathrm{h}$ was used in planning the test to allow for the range of cesium compositions expected in the actual waste. Oxygen was generated by the decomposition of hydrogen peroxide. Column differential pressures, the volume of gas generated, and the column bed heights were measured. The bed was also monitored for bubble formation and gas accumulation. The test was run at a nominal superficial liquid velocity of $4.1 \mathrm{~cm} / \mathrm{min}$.

\subsection{FLOWSHEET}

A peroxide pump and supply vessel were added to the system for this test, as shown in Fig. 6.1. Before the test, the peroxide-metering pump and the feed pump were calibrated and the static pressures were obtained. Initially, a simulated salt solution spiked with hydrogen peroxide was fed into the feed tank. The hydrogen peroxide was either adsorbed on the IONSIV® IE-911 or decomposed (catalyzed by metals in the CST), generating oxygen gas. As discussed in Sect. 6.4, the configuration was modified during the test to introduce the feed directly to the top of the bed-after it was determined that hydrogen peroxide was disappearing from the feed, presumably because of something in the recycled simulant from the column. This revised configuration is indicated by the shaded elements in Fig. 6.1. (See P\&ID in Apendix A.)

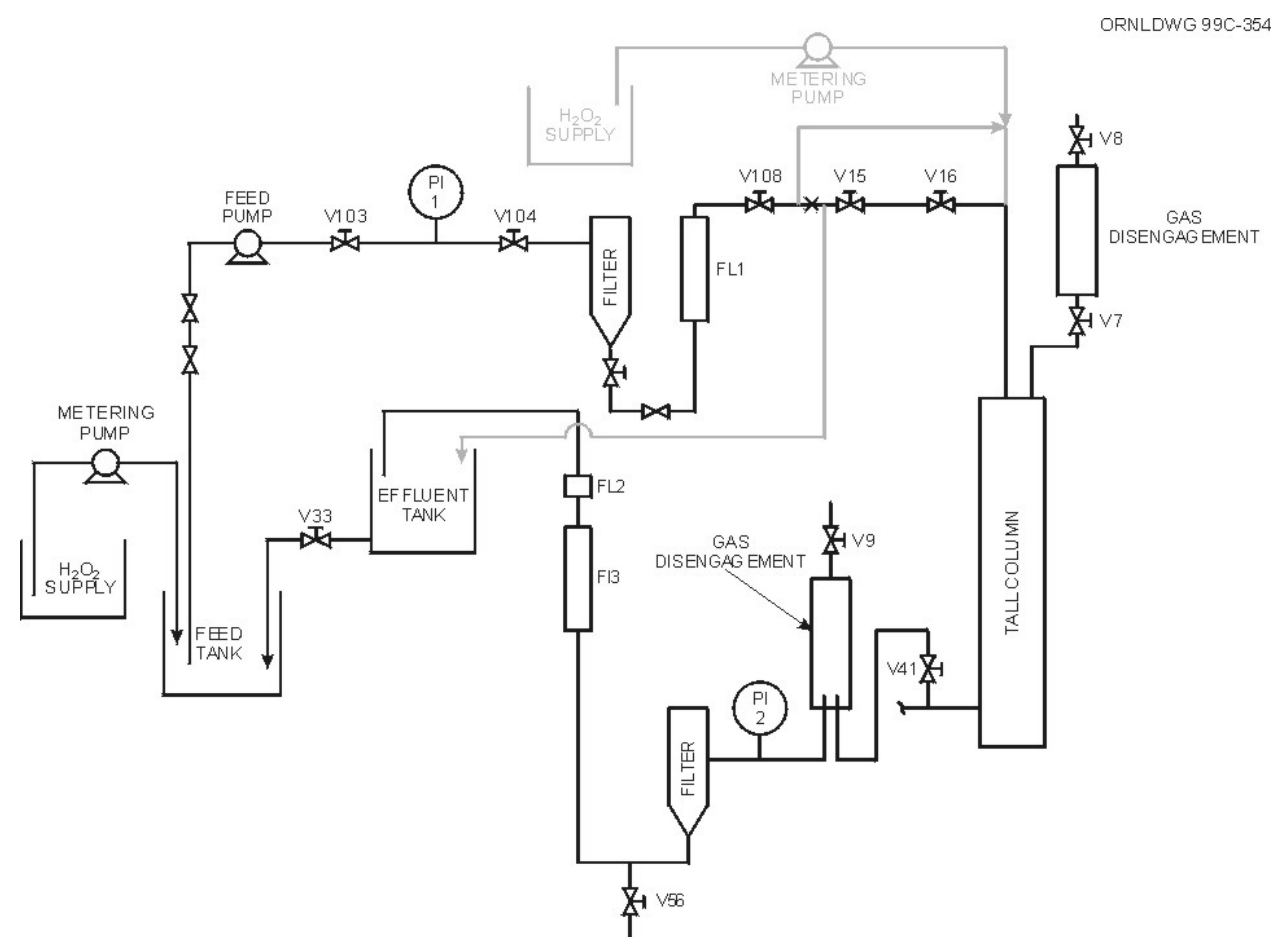

Fig. 6.1 Simplified flowsheet showing the configuration for the gas-behavior tests. 
Table 6.1 lists the initial gas-test parameters. The target peroxide feed concentration of 0.001 wt $\%$ was derived from analysis of small-scale column test results.

Table 6.1 Conditions for column gas test

\begin{tabular}{ll}
\hline \multicolumn{1}{c}{ Parameter } & \multicolumn{1}{c}{ Value } \\
\hline Liquid superficial velocity & $4.1 \mathrm{~cm} / \mathrm{min}$ \\
Feed flow rate & $187 \mathrm{~cm}^{3} / \mathrm{min}$ \\
Bed residence time & $47 \mathrm{~min}$ \\
Feed tank residence time & $200 \mathrm{~min}$ \\
Target gas-generation rate & $40-320 \mathrm{~cm}^{3} / \mathrm{h}$ \\
Peroxide concentration in the feed (initial) & $0.001 \mathrm{wt} \%$ \\
\hline
\end{tabular}

\subsection{NITRITE EFFECT UPON CHEMICAL ANALYSES}

The concentrations of peroxide in the feed and in the effluent were measured by permanganate titration of samples that were collected periodically. The nitrite and oxalate were omitted from the simulant that was prepared for the gas-generation tests. The nitrite and oxalate do not react with peroxide in the alkaline simulant solution; however, when samples are acidified for the permanganate titration, both nitrite and oxalate react rapidly with peroxide and permanganate.

Before the gas test, the original simulant in the column was replaced by displacing it with $2 \mathrm{M}$ $\mathrm{NaOH}$ and flushing with three additional column volumes of $\mathrm{NaOH}$. The concentration of nitrite in the effluent was monitored until the apparent nitrite concentration was less than $20 \mathrm{ppm}$. Then the $2 M \mathrm{NaOH}$ was replaced with the new nitrite-free simulant. Despite efforts to rinse the column using batches of caustic solution, some nitrite managed to remain, possibly in interstitial liquid that diffused out of the CST during the lengthy recycle of simulant and peroxide.

\subsection{STARTUP: DISAPPEARING PEROXIDE}

After simulant flow was started, hydrogen peroxide was added to the feed tank to bring the feed tank concentration up to the desired level. Then hydrogen peroxide was added continuously to the feed tank using a metering pump. The initial hydrogen peroxide concentration sampled from the feed tank was in the target range, but within several hours the feed concentration was about one-half of the expected value. Additional peroxide was spiked into the feed tank, but the measured peroxide concentration did not increase. About $10 \mathrm{~h}$ into the test, the feed flow was stopped to investigate this phenomenon and the source of black solid that had been observed in some of the feed samples. When the flow was stopped, a white cloud was observed above the bed (Fig. 6.2). Flow was restarted, and again the feed concentration drifted down below the target concentration, even after the feed tank was spiked with peroxide. Based on the reaction kinetics and the adsorption isotherm for peroxide obtained from laboratory tests, we had expected to see indications of gas generation in the top of the bed immediately and to load the column with peroxide within $24 \mathrm{~h}$ of startup. However, this did not occur. In addition, the 


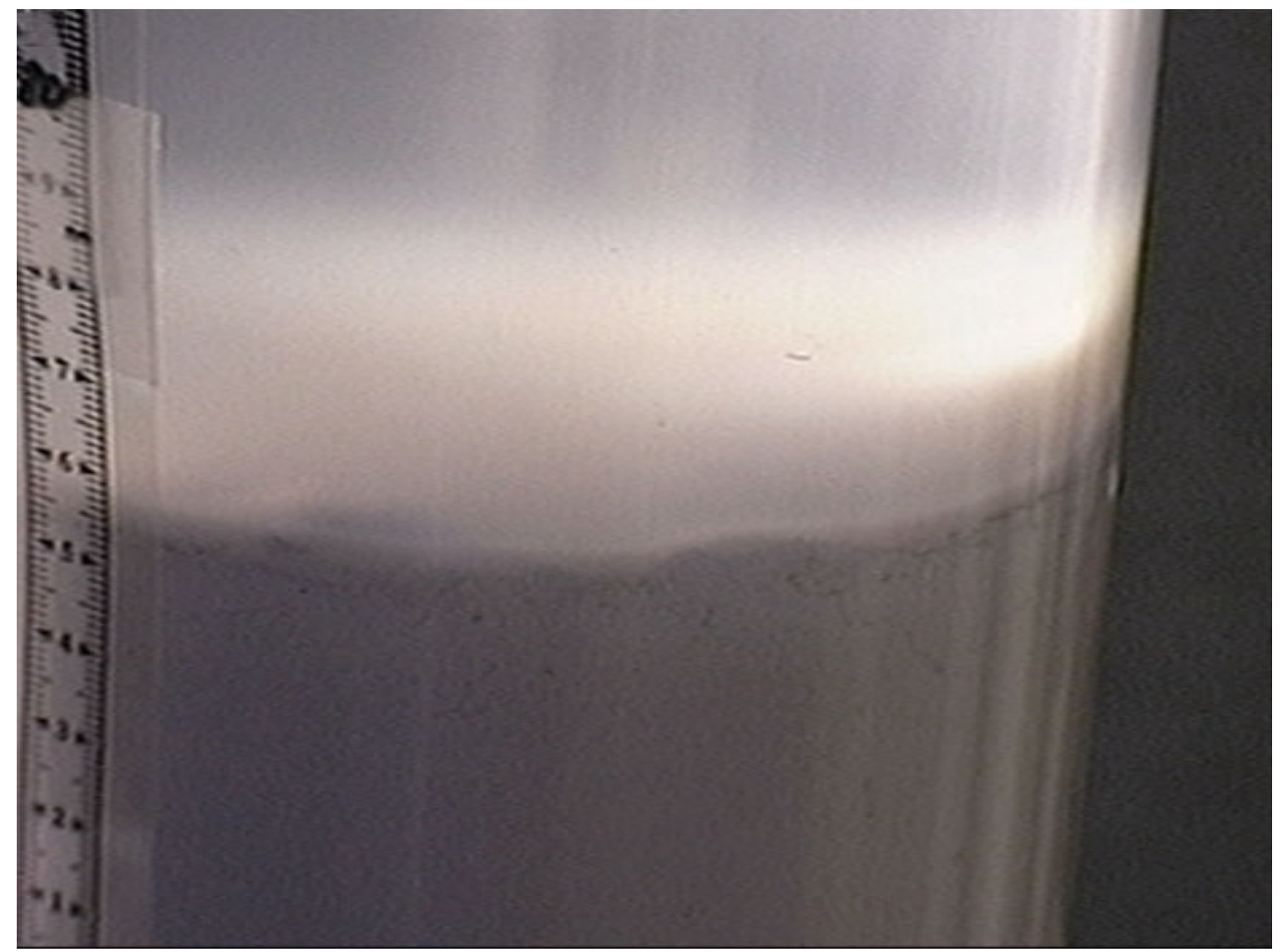

Fig. 6.2. Cloud of fine solids observed above the bed when the feed was stopped.

apparent hydrogen peroxide concentration in the effluent was nearly constant at $0.0027 \mathrm{wt} \%$ over several hours.

Spot tests with manganese dioxide solid to test for the presence of hydrogen peroxide were negative, indicating that we were titrating not peroxide but some other reductant. A nitrite concentration of $48 \mathrm{mg} / \mathrm{L}$ would give the same titration result as a peroxide concentration of $0.0027 \mathrm{wt} \%$. The samples were analyzed for nitrite using an ion-specific electrode and were found to contain $44 \mathrm{mg} / \mathrm{L}$ of nitrite. Therefore peroxide-free solution with $\sim 44 \mathrm{mg} / \mathrm{L}$ nitrite exited the bottom of the column.

A grab sample collected from the feed tank was analyzed for hydrogen peroxide over time after being spiked, and this was compared with a sample of nitrite-free simulant obtained from the simulant storage vessel. As seen in Fig. 6.3, it was apparent that something in the simulant from the column system was reducing the measurable peroxide in solution.

The peroxide was being consumed or bound before reaching the column. Batch lab tests were conducted with simulant and CST collected from the column system to investigate what was 


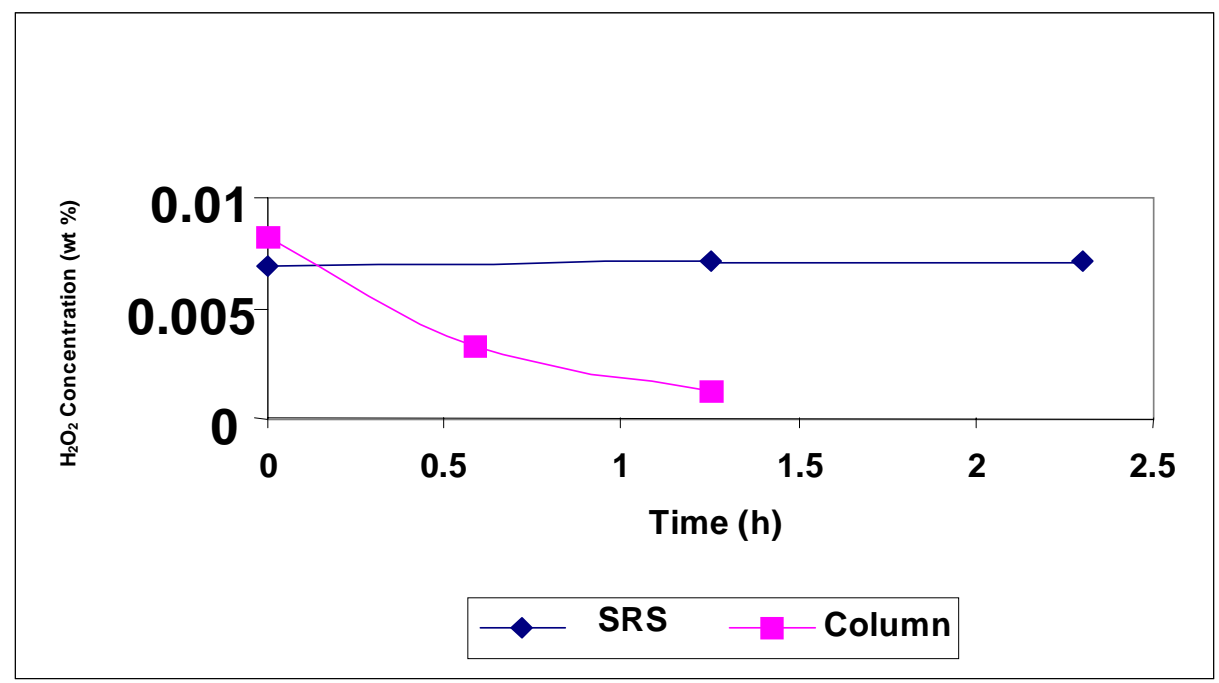

Fig. 6.3. Disappearance of hydrogen peroxide from column simulant and from fresh SRS simulant.

happening to the peroxide and to determine how to proceed. Results from this test indicated that the peroxide decomposition reaction was viable in the column but that the apparent catalytic activity was lower when compared with that of batch laboratory results from previous tests with fresh CST.

\subsection{SYSTEM MODIFICATION AND RESTART}

To avoid peroxide consumption in the feed tank, the system was modified so that hydrogen peroxide could be introduced directly above the bed with the feed. A 1/4-in. tube was inserted through the 1-in. feed pipe from the top of the column to just above the bed (Figs. 6.1 and 6.4). Hydrogen peroxide was mixed with the feed at the top of the column and pumped down the $1 / 4$-in. tube.

\subsection{GAS FLOW}

Hydrogen peroxide loaded on the bed relatively quickly after the modification. Figure 6.5 shows the concentration of peroxide in the column feed and the volume of gas that exited the column. About $9.5 \mathrm{~h}$ after the peroxide was introduced into the column with the modified feed configuration, the first measurable volume of gas was released from the effluent. Gas bubbles seen at the inside surface of the column wall gave a visual indication of the progress of the gas wave down the column. Based on the visible gas voids, gas breakthrough occurred after about $9 \mathrm{~h}$. Before it reached the gas disengagement tube, gas accumulated in the effluent line until a sufficiently large bubble formed such as to reach the tee leading to this chamber. Much of this gas was then released and flowed to the disengagement tube, where it arrived as a cluster of bubbles. 


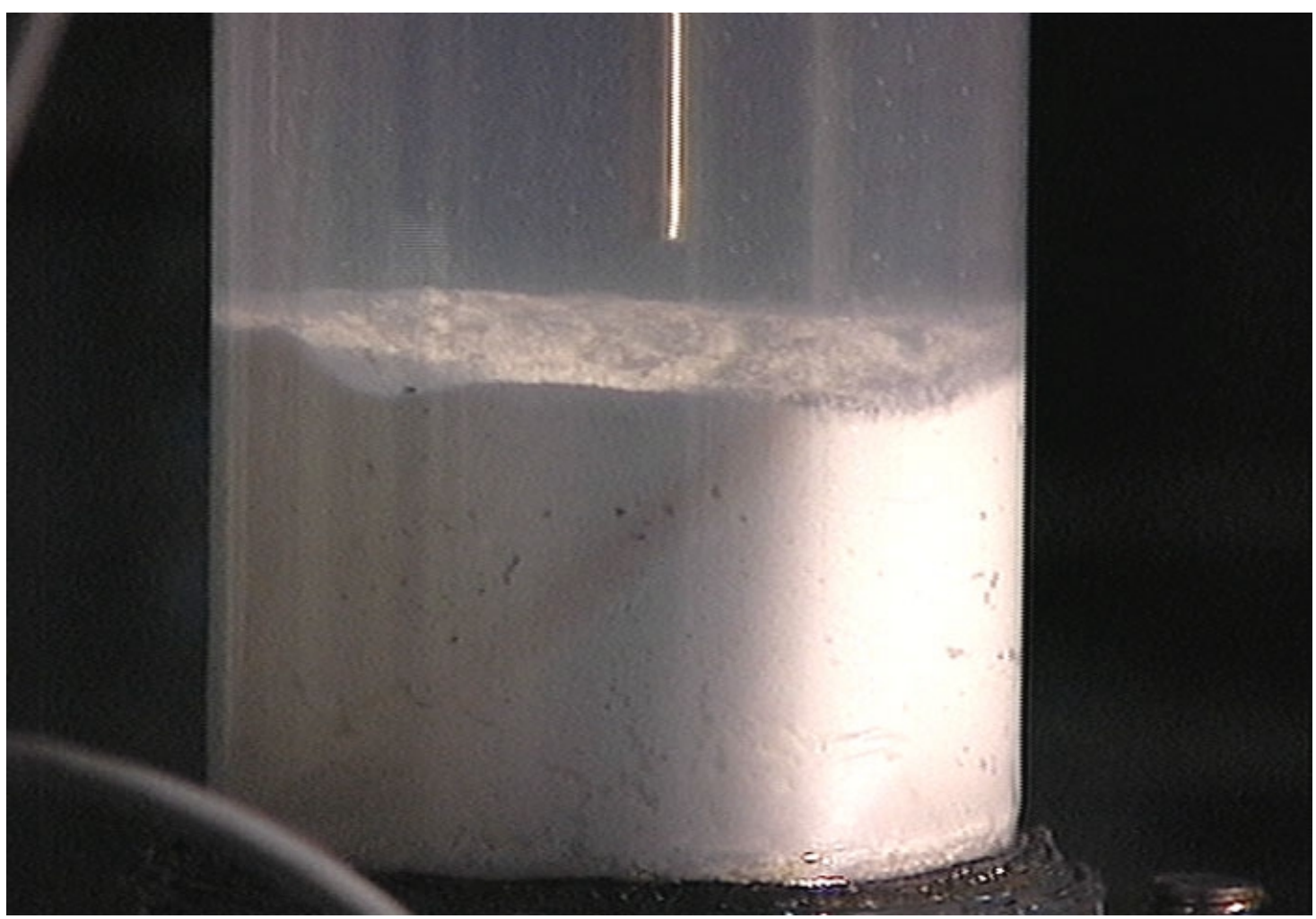

Fig. 6.4. Feed introduced through the 1/4-in. tubing to just above the bed.

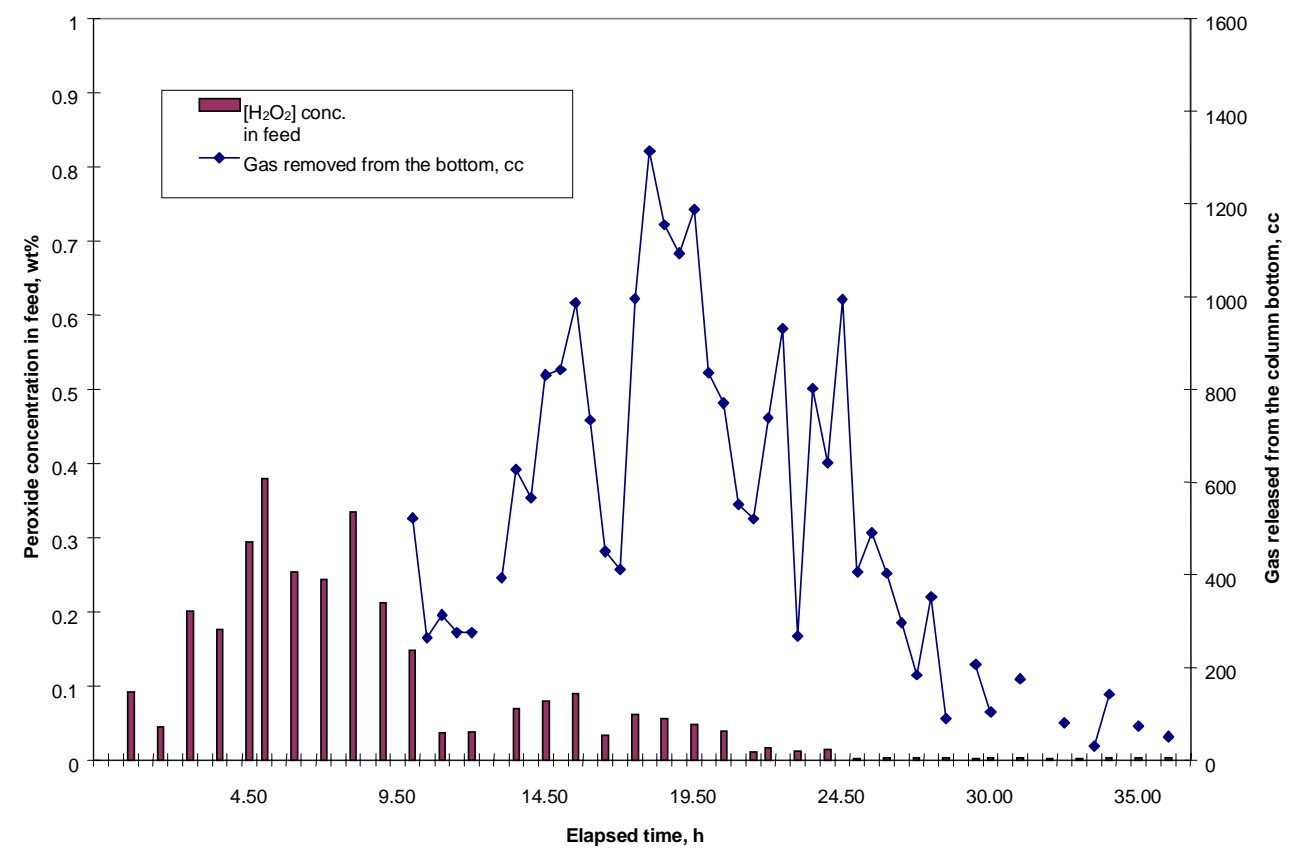

Fig. 6.5. Peroxide concentration in the feed and the volume of gas carried out with the effluent stream. The elapsed time refers to the time after the system was modified and restarted. 
Gases generated in the column were swept out of the bottom of the column with the effluent, regardless of the gas-generation rate. No gas was observed escaping from the top of the bed. No bed expansion was observed while the column was operated in downflow, even at gas evolution rates 16 times the target rate of $82 \mathrm{~cm}^{3} / \mathrm{h}$. It is apparent that some gas does accumulate in the bed, as is evident from the gas bubbles that are visible at the inside column wall (Fig. 6.6). When flow to the top of the column was stopped at the end of the gas test, 1.3 L of gas bubbled up from the bed to the top of the column in about $40 \mathrm{~min}$. The volume of gas was based on the liquid level at the top of the column after shutdown. A majority of this gas is believed to be from that accumulated in the CST bed, and the remainder is assumed to be the result of gas generation.

At the beginning of the test, we planned to introduce hydrogen peroxide into the feed at a concentration of $0.001 \mathrm{wt} \%$. The target peroxide concentration was increased to $0.2 \mathrm{wt} \%$ after the system was modified to introduce feed to the top of the bed. However, as is apparent in Fig. 6.7, the peroxide concentration of the feed fluctuated by as much as two times this new target concentration. As a result, gas-generation rates fluctuated as well. The fluctuation in the feed peroxide concentration resulted from the delivery of peroxide by the MasterFlex pump (Fig. 6.7).

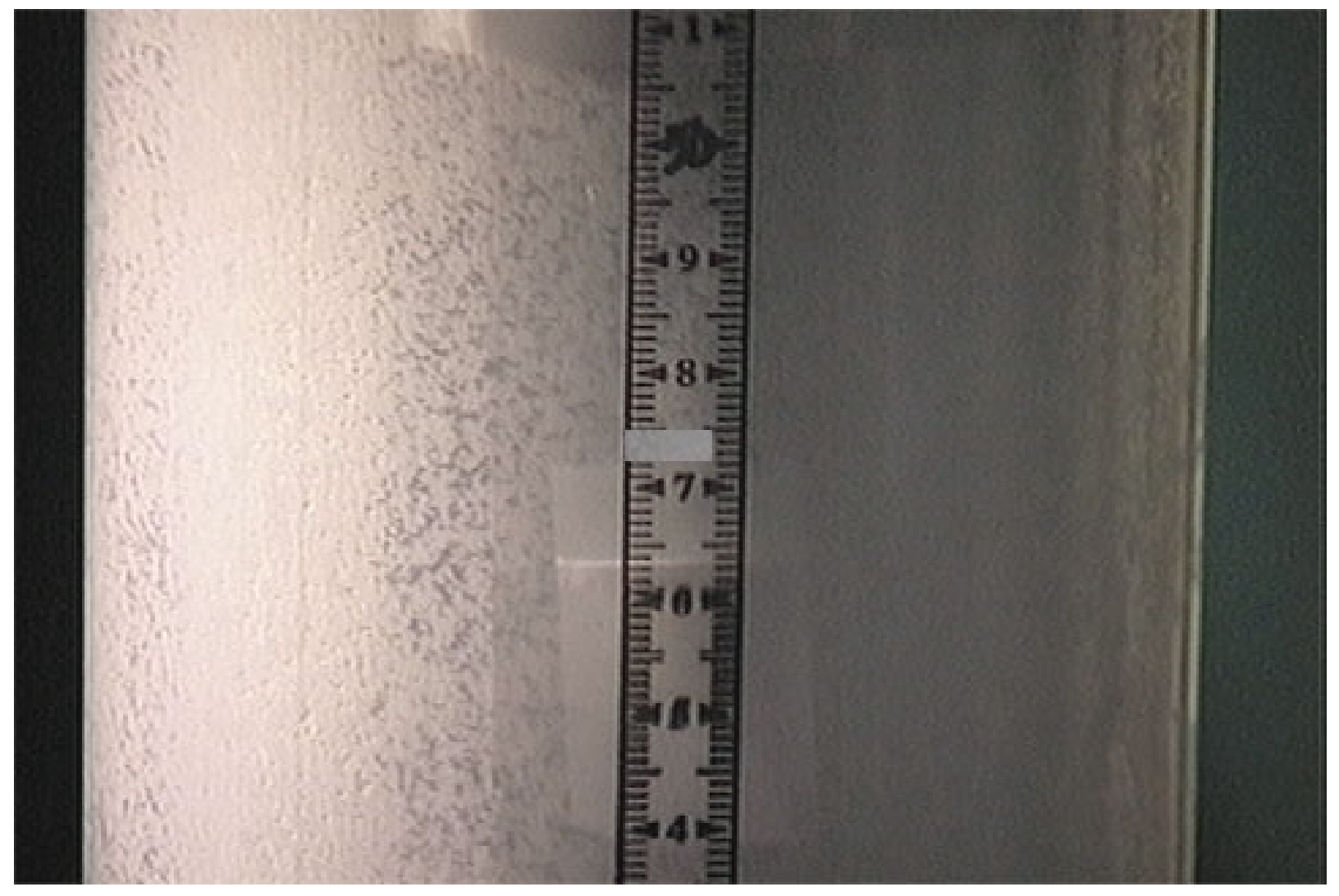

Fig. 6.6. Gas voids visible at the column wall. 


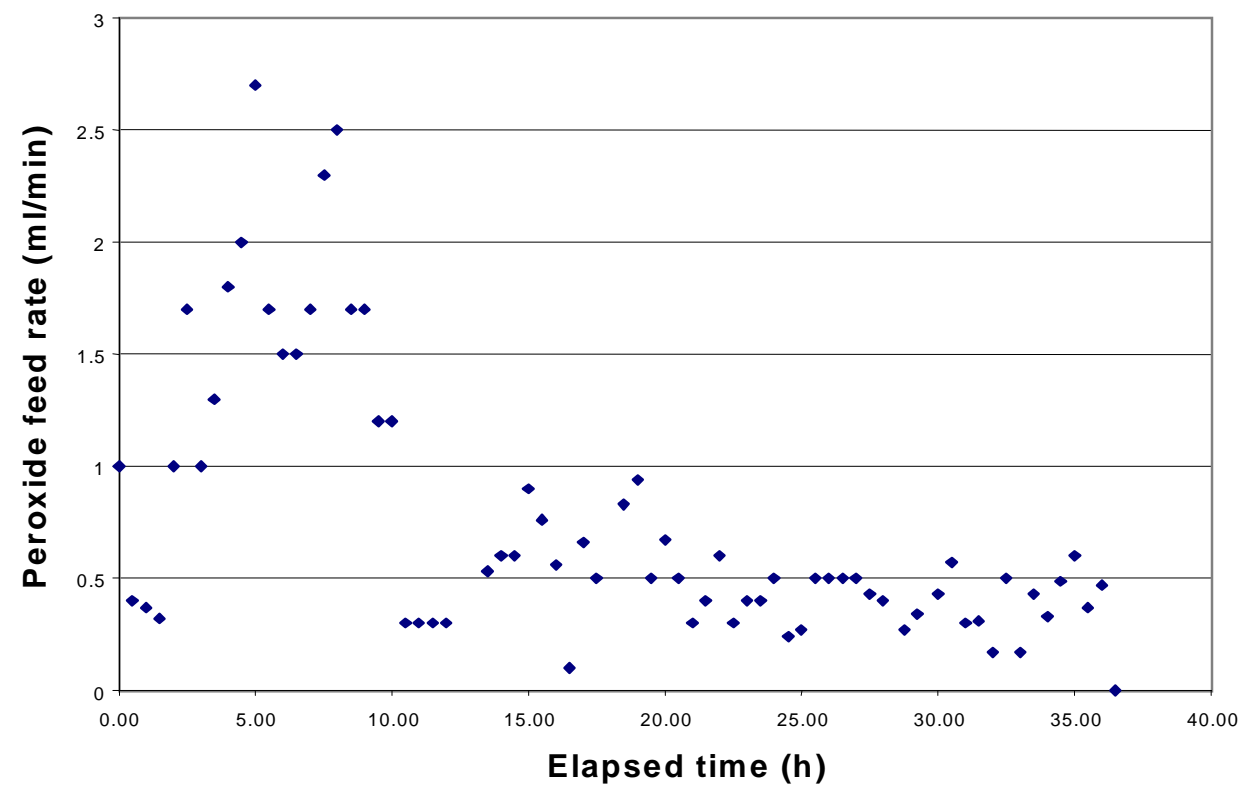

Fig. 6.7. Erratic hydrogen peroxide flow rate. The elapsed time refers to the time after the system was modified and restarted.

After restarting with hydrogen peroxide being introduced at the top of the bed, gas-generation rates in the desired range of 40 to $320 \mathrm{~cm}^{3} / \mathrm{h}$ were obtained shortly after gas breakthrough and in the final $10 \mathrm{~h}$ of the test. However, during most of the test, the generation rate was well above the upper target range. To bring the gas-generation rate into the desired range, the peroxide supply concentration was reduced, as shown in Table 6.2. The resulting peroxide concentration in the feed was about $0.003 \mathrm{wt} \%$ at the end of the test, or about three times the initial estimate.

The first gas breakthrough was seen after $9.5 \mathrm{~h}$. Hydrogen peroxide breakthrough is predicted in 4 to $10 \mathrm{~h}$, depending on how the isotherm is drawn through the data points on the hydrogen peroxide isotherm, as shown in Fig. 5.3. Figure 6.5 suggests that the lag time between a change in the feed and the corresponding response in the effluent gas rates is on the order of 9 to $10 \mathrm{~h}$. The lag could be caused by adsorption-desorption of peroxide and oxygen. Additional column data would be required to determine the time lag, and refinement of the hydrogen peroxide isotherm would be required to sort out the mechanisms.

Table 6.2. Hydrogen peroxide supply concentration after restart with hydrogen peroxide addition closer to top of the bed

\begin{tabular}{cc}
\hline Elapsed time (h) & $\begin{array}{c}\text { Hydrogen peroxide concentraton } \\
(\text { wt } \%)\end{array}$ \\
\hline $0-15.50$ & 30 \\
$15.50-18.25$ & 24 \\
$18.25-21$ & 15 \\
$21-24.50$ & 7.5 \\
$25.50-37$ & 1.5 \\
\hline
\end{tabular}




\subsection{PRESSURE DROP INCREASE WITH GAS INVENTORY}

Figure 6.8 shows the bed pressure drop over the entire gas-behavior test. Gas was generated during the period 50 to $82 \mathrm{~h}$. Flow to the column was shut off during the time periods of 10 to $18 \mathrm{~h}$ and 43 to $46 \mathrm{~h}$ (see Fig. 6.8). The periodic downward spikes in the pressure correspond to withdrawal of feed and effluent samples from the system. This sampling period is more apparent in Fig. 6.9. Gas accumulation in the column resulted in a bed pressure drop 2 to 2.5 times greater than that obtained earlier in the test before the occurrence of gas generation (Fig. 6.8). Figure 6.10, which expands the timescale of Fig. 6.8, shows the bed pressure drop for the period in which peroxide was blended with the feed and introduced to the top of the column. The bed pressure drop was in the 8- to 9-psig range. Comparison of this pressure-drop profile with that for the gas release rate, as shown in Fig. 6.5, suggests that after a quasi-steady-state gas inventory has been established in the column (i.e., once gas voids form in the column), the gas inventory is only weakly affected by the generation rate.

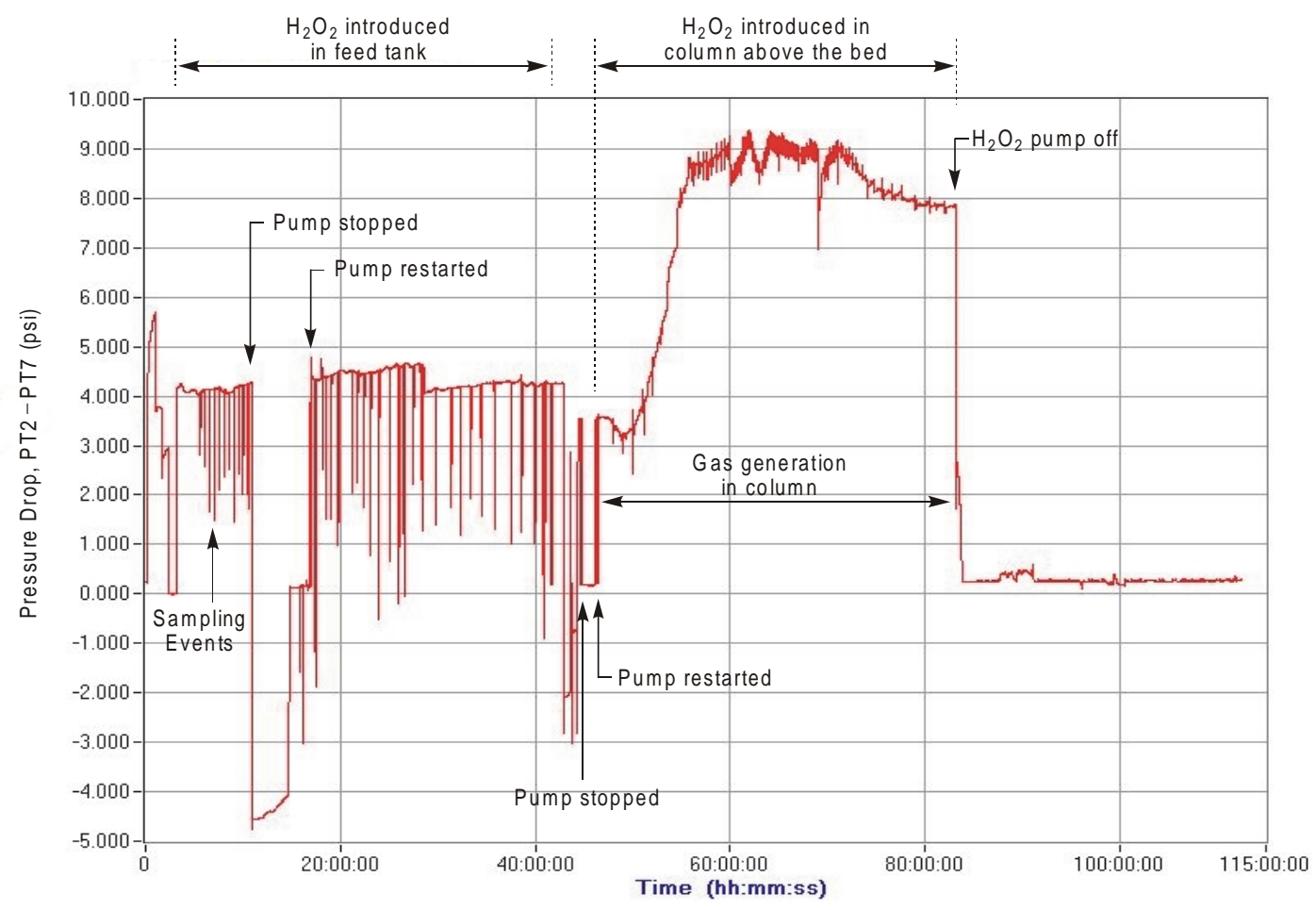

Fig. 6.8. Pressure drop in bed during gas test.

The gas-generation tests demonstrated that gas accumulation in the bed is limited and does not expand the bed within the expected operating conditions. Gases flow out of the column with the effluent. The column pressure drop doubles when the bed contains accumulated gases. The magnitude of the pressure drop is only weakly dependent on the gas-generation rate. The column was able to eliminate 16 times the design-maximum gas-generation rate without apparent disruption of the bed. 


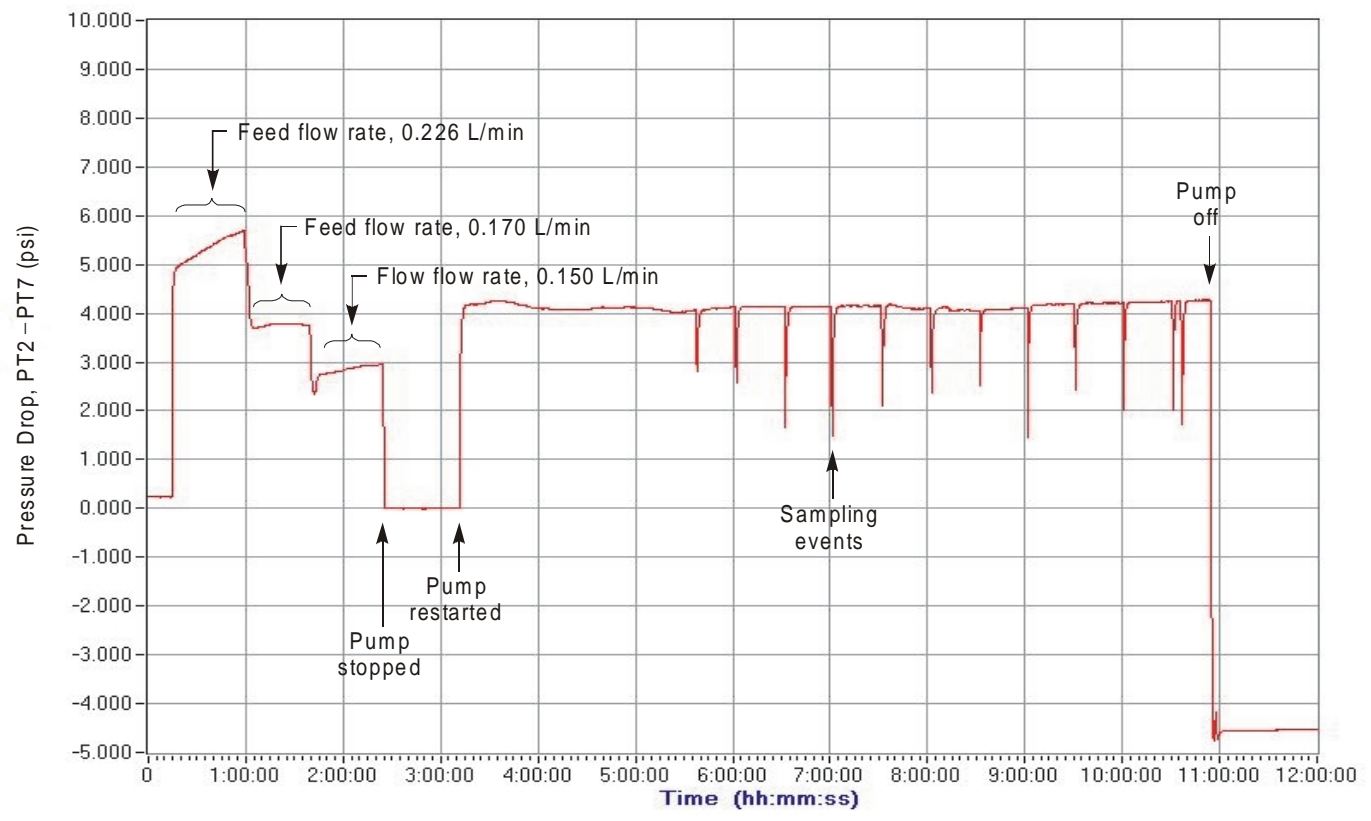

Fig. 6.9. Pressure drop early in the test during initial flow rate calibrations and effect of sampling.

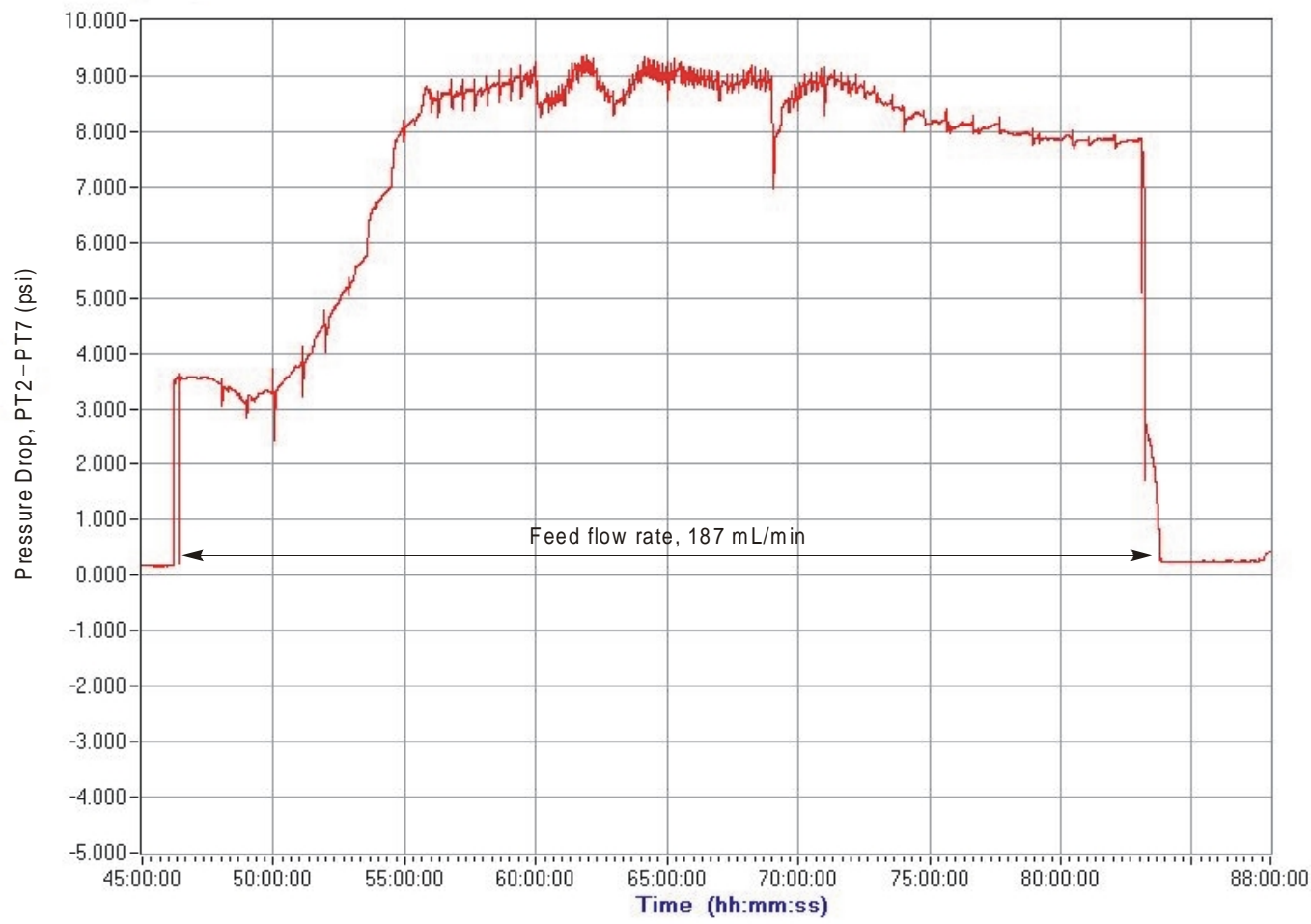

Fig. 6.10. Pressure drop in bed after feed was introduced at the top of the bed. 


\section{RESULTS FROM ANCILLARY TESTS AND ANALYSES}

In the course of the loading, hydraulic, and gas tests, a number of supporting tests and analyses were performed. The results of these tests are reported in this section.

\subsection{PARTICLE-SIZE DETERMINATION}

The CST was sampled at several locations along the tall column once the column had been loaded with pretreated IONSIV® IE-911 (lot no. 99909881006) and backwashed. Samples ( 10 g each) of the CST were collected from the "top," "middle," and "bottom" ports located at 4, 2 , and $0 \mathrm{~m}$, respectively, from the base of the column. These samples represent variations in particle size of the sorbent before column testing. The CST samples were acquired as slurries withdrawn from column sample ports. They were allowed to settle overnight; the fines suspended in the supernatant were then withdrawn from the individual samples. The bulk of the samples and their respective suspended solids fractions were air dried. Once the weight of dried suspended solids was determined (less than $0.1 \%$ of total sample mass), the solids were returned to the bulk port sample and the entire sample was then sieved for particle-size distribution.

Each port sample was placed in the top of a series of sieve pans spanning the range of 30-120 mesh $(125-590 \mu \mathrm{m})$; a solid pan was placed at the bottom of the sieves to collect the sorbent fines. The stack of sieve trays was shaken for 20 min on a CSC Scientific Corp. model 18-480 sieve shaker at a setting of $50 \%$ full power. The contents of each sieve were then weighed to determine the amount of sorbent collected in each size range. Sieving results for CST samples from the top port of the column are presented in Table 7.1. The standard deviation in mesh size was based on the weight percent of CST for a particle size representing the midpoint diameter (in units of micrometers) for a given sieve pan.

Table 7.1. Weight distribution of CST at the top port of the column

\begin{tabular}{lllc}
\hline $\begin{array}{c}\text { U.S. sieve } \\
(\mathrm{mesh})^{a}\end{array}$ & \multicolumn{1}{c}{$\begin{array}{c}\text { Particlesize } \\
(\mu \mathrm{m})\end{array}$} & $\begin{array}{c}\text { Net weight } \\
(\mathrm{g})\end{array}$ & $\begin{array}{c}\text { Percentage of } \\
\text { total weight }\end{array}$ \\
\hline 30 & 595 & 0.0020 & 0.02 \\
40 & $420-590$ & 3.0458 & 36.99 \\
50 & $297-420$ & 5.0905 & 61.83 \\
80 & $177-297$ & 0.0054 & 0.07 \\
100 & $149-197$ & 0.0004 & 0.00 \\
120 & $125-149$ & 0.0017 & 0.02 \\
120 & $<125$ & 0.0126 & 0.15 \\
Total & & 8.16 & 99.09 \\
\hline
\end{tabular}

${ }^{a}$ Average. mesh size of sample $=412 \mu \mathrm{m}$; standard deviation of mesh size $=71 \mu \mathrm{m}$. 
Larger samples of CST were withdrawn at $0 \mathrm{~m}$ from the base of the column and at $4 \mathrm{~m}$ from the base of the column after testing was completed. The $\sim 400$-g samples were air dried; a riffler was used to obtain three 50-g subsamples. Finally, an $\sim 300-\mathrm{g}$ grab sample of unused CST was collected from a 5-gal bucket containing the supply of CST that was used in the tall column, which had just been rolled to mix the contents. This sample represents the pretreated CST before its loading in the tall column and before fines were removed by backwashing. Again, three riffled samples were split from the 300 -g sample and used to estimate the original particle size of the pretreated CST. Figure 7.1 shows the particle-size distribution of CST source material and of CST sample collected from three different column location.
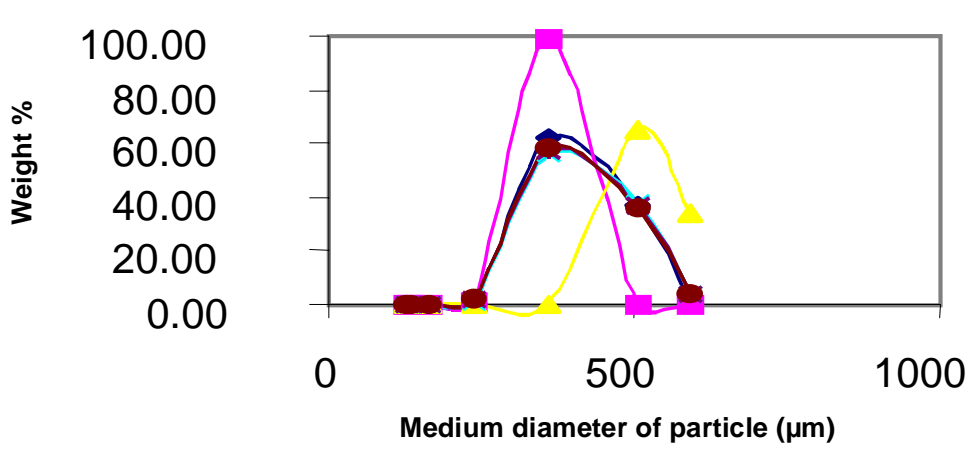

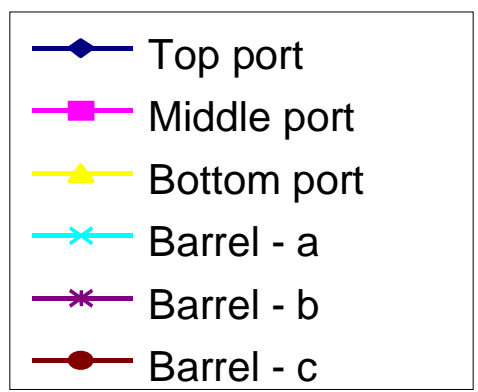

Fig. 7.1. Particle-size distribution of CST samples collected after backwashing and samples from the source barrel. The letters $a, b$, and $c$ refer to triplicates of the same sample.

The mesh size for each 10-g port sample and the average mesh size for triplicates of the samples collected 0 and $4 \mathrm{~m}$ from the base and from the destination barrel are given in the Table 7.2. The standard deviations in Table 7.2 represent variation in the average mesh size calculated for each sieve test for the pretreated IONSIV® IE-911. Data for which particle size was determined for triplicate samples indicate that the standard deviation is excellent $(< \pm 0.1 \%)$ for replicate samples. Therefore, variation in the average particle size between CST grab samples is experimentally significant.

Unlike any other sample, the 400-g grab sample, which was collected at the base of the column, clumped badly during air drying. The caked CST from the 0 -m column position could not be easily dispersed into individual resin beads. Even after a 20-min sieving procedure, a number of clumps were visible in the 30 mesh $(>595 \mu \mathrm{m})$ sieve tray. Additionally, the CST was more difficult to remove from the sieve screen. Once pushed out of a screen for collection, the CST would often reattach to the wire mesh. The 30 mesh fraction from one of the triplicate samples 
Table 7.2. Overall sieve analysis results for CST column samples

\begin{tabular}{lccc}
\hline Column sample & $\begin{array}{c}\text { Average particle } \\
\text { size } \\
(\mu \mathrm{m})\end{array}$ & $\begin{array}{c}\text { Standard deviation } \\
\text { within run } \\
(\mu \mathrm{m})\end{array}$ & $\begin{array}{c}\text { Standard deviation } \\
\text { between runs } \\
(\mu \mathrm{m})\end{array}$ \\
\hline Top port & 412 & 71 & --- \\
Middle port & 357 & 16 & --- \\
Bottom port & 534 & 42 & --- \\
0 m from base & $526^{a}$ & $50^{a}$ & 3 \\
4 m from base & $362^{a}$ & $42^{a}$ & 1 \\
$\quad \begin{array}{c}\text { Destination } \\
\text { barrel }\end{array}$ & 420 & 81 & 3 \\
\hline
\end{tabular}

${ }^{a}$ Average of three sieve test results for given sample.

was received after an effort was made to roll out the clumps into individual particles. The fraction divided primarily into 70\% 30 mesh and 26\% 40 mesh particles. These data were used to recalculate the average mesh size of this particular sample, altering the value from 523 to $515 \mu \mathrm{m}$. Values stated in Table 7.1 are results acquired using only a single sieve of the original sample. Figure 7.2 shows the particle size distribution of samples collected from the column after the completion of the gas behavior tests.

To summarize, fines production was nonexistent. CST size redistribution occurred along the column after backwashing, with the largest particles at the base of the column.

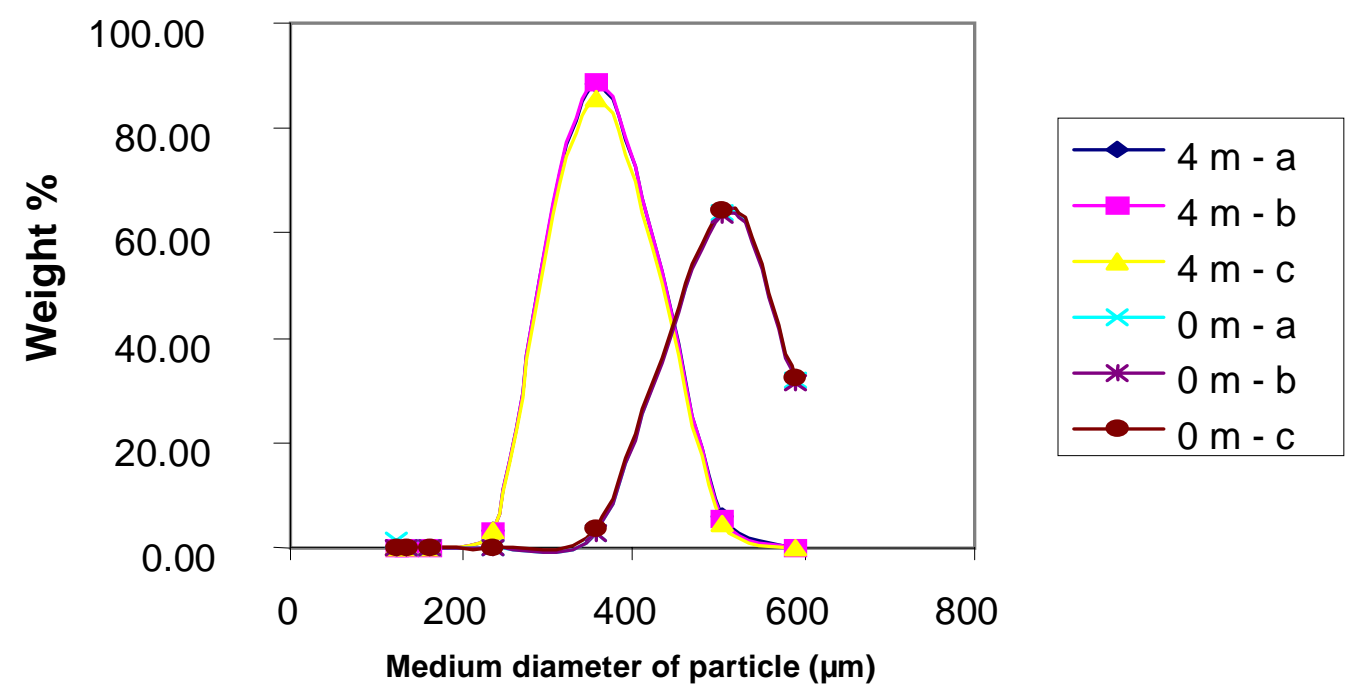

Fig. 7.2. Comparison of particle-size distribution of CST samples from the top and bottom of the column before unloading. The letters $a, b$, and $c$ refer to triplicates from the same sample. 


\subsection{PARTICLE ANALYSIS}

Samples of CST were collected from the top of the bed at the end of hydraulic test 4 . The pressure drop across the top of the bed had increased, and a discolored band was visible at that location. Because there were stagnant zones in the column containing water, it was suspected that the $\mathrm{pH}$ may have been lowered in this stagnant zone and that aluminosilicate precipitates may have formed. These samples and, for comparison, a sample that had not been in the column were analyzed by scanning electron microscopy (SEM) and energy dispersive X-ray spectroscopy (EDX). Figure 7.3 shows the SEM photomicrograph for the baseline CST material. The material is spheroidal (with some broken particles) and contains particles in the 400- to $600-\mu \mathrm{m}$-diam range. A magnified view of one of these particles is shown in Fig. 7.4. The particles have a relatively smooth surface, which has micropores. The SEM photomicrograph of a sample collected from the top of the column, after backwashing, is shown in Fig. 7.5. This material is largely broken, and the size of the particles is $<400 \mu \mathrm{m}$. It is thought that these pieces were from the source material or had been generated during loading but that they had not been removed during the backwashing operation. The EDX spectrum indicated that the silicon content was lower in this material than in the original CST, whereas the aluminum and calcium contents were more abundant. A calcium-rich precipitate particle was identified in this sample. The source of the calcium was probably the process water used to make up the simulant.

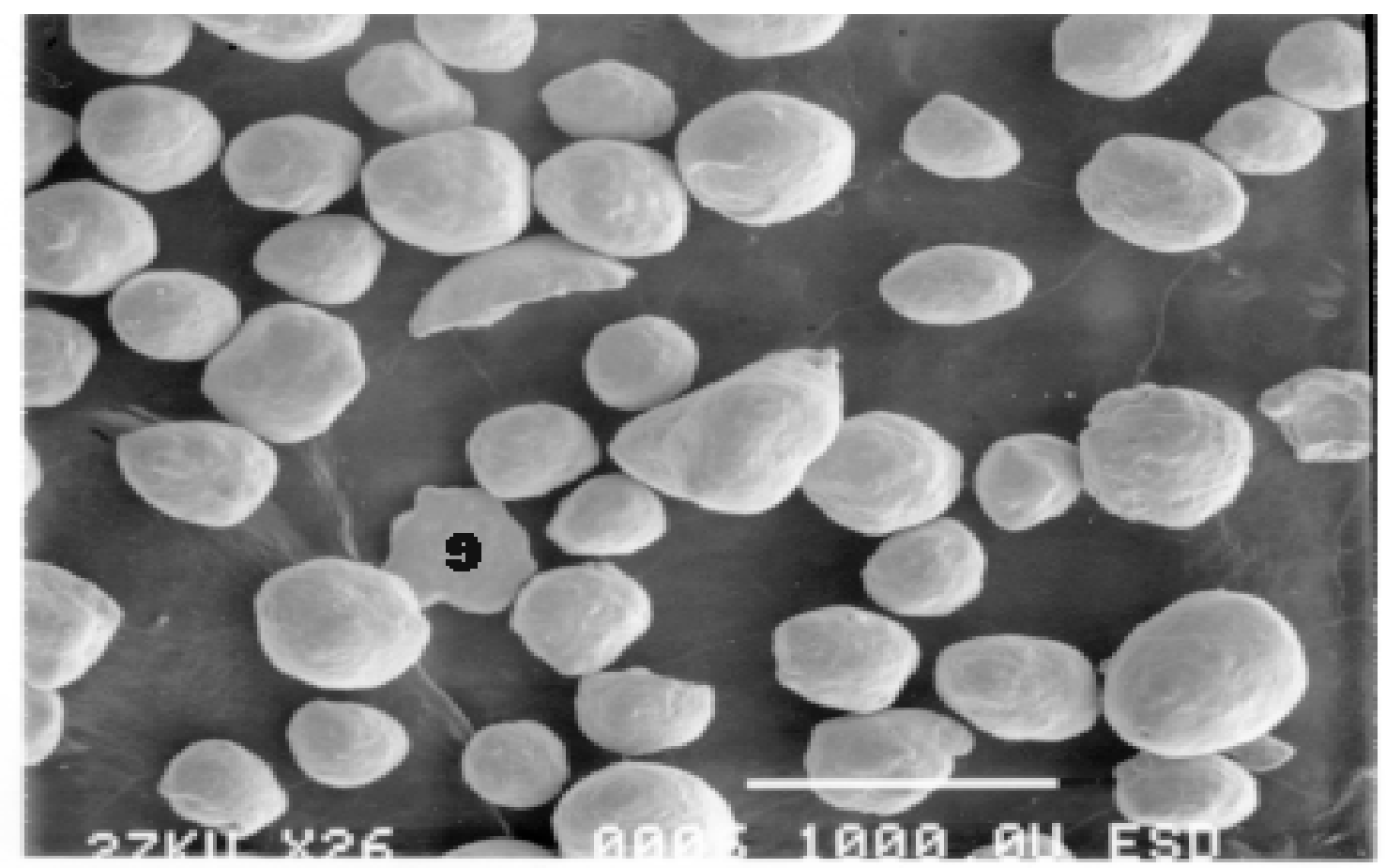

Fig. 7.3. SEM photomicrograph of baseline CST lot no. 999098810006. This material was pretreated with $\mathrm{NaOH}$ and is representative of the material that was sluiced into the column. 


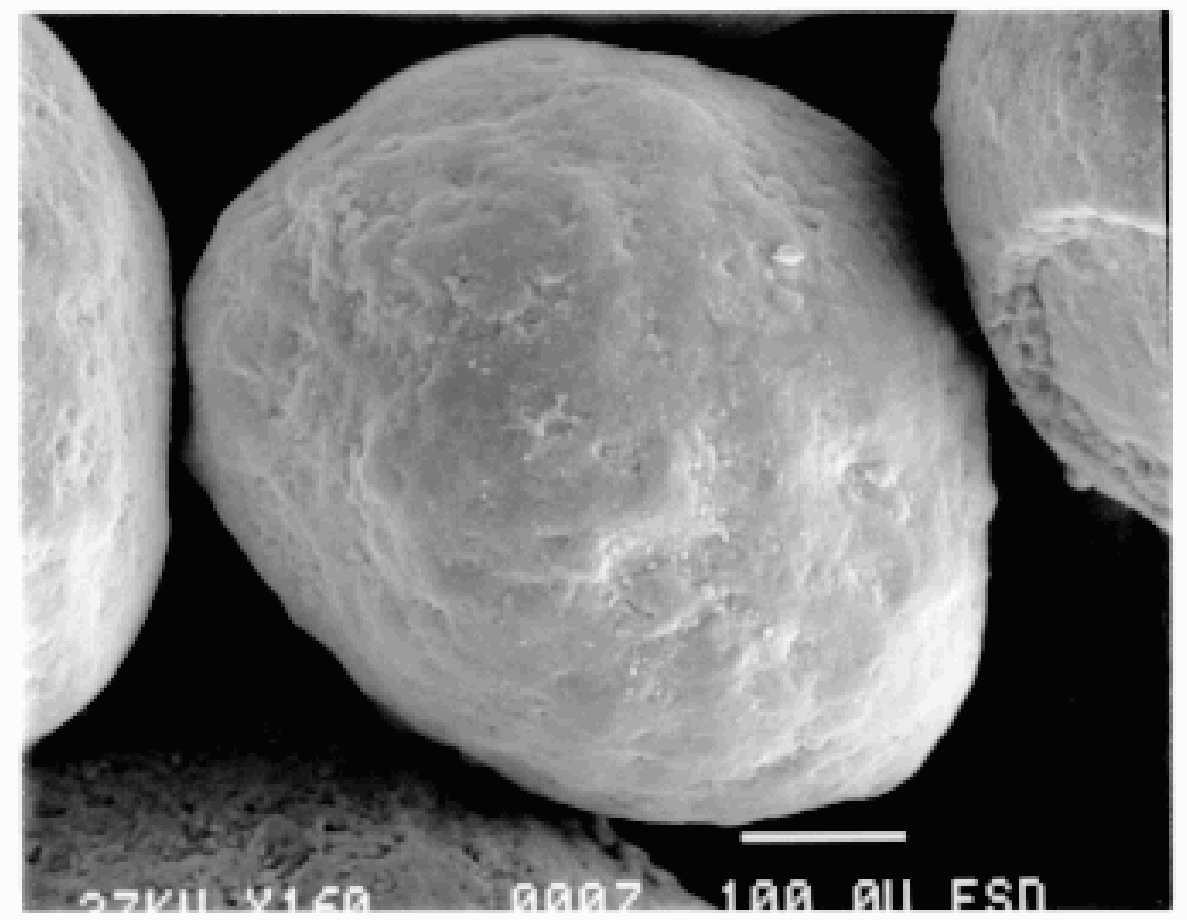

Fig. 7.4. Magnified view of baseline CST particle.

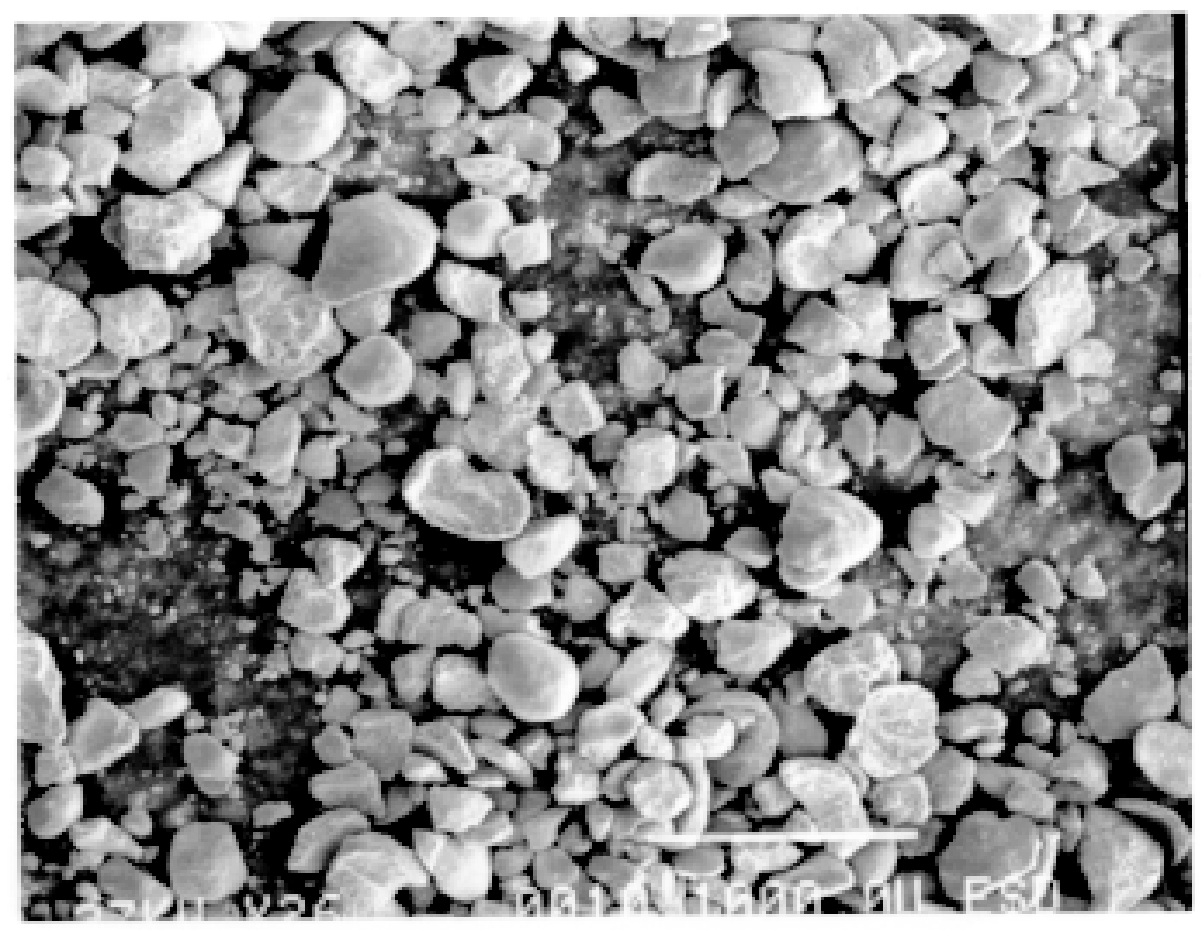

Fig. 7.5. SEM photomicrograph of particles collected from the top of the bed after hydraulic test 4 . 
After the hydraulic and gas tests were completed, but before unloading, CST samples were collected near the top and the bottom of the bed. Figure 7.6 shows the SEM photomicrograph of the material collected near the top of the bed, and Fig. 7.7 shows that for the material collected from the bottom. The distribution of particle sizes was achieved during backwashing, which resulted in the particles near the top being smaller than those at the bottom. Closer examination of the surface of the larger particles from the bottom sample (Fig. 7.8) revealed round precipitate nodules containing aluminum and silica on the surface. This material was taken from the bottom of the column, where a stagnant water zone was present for the first four hydraulic tests. Water reduced the $\mathrm{pH}$ and ionic strength of the simulant in this zone. See Appendix B for a discussion of how dilution of simulant can result in the formation of solids.

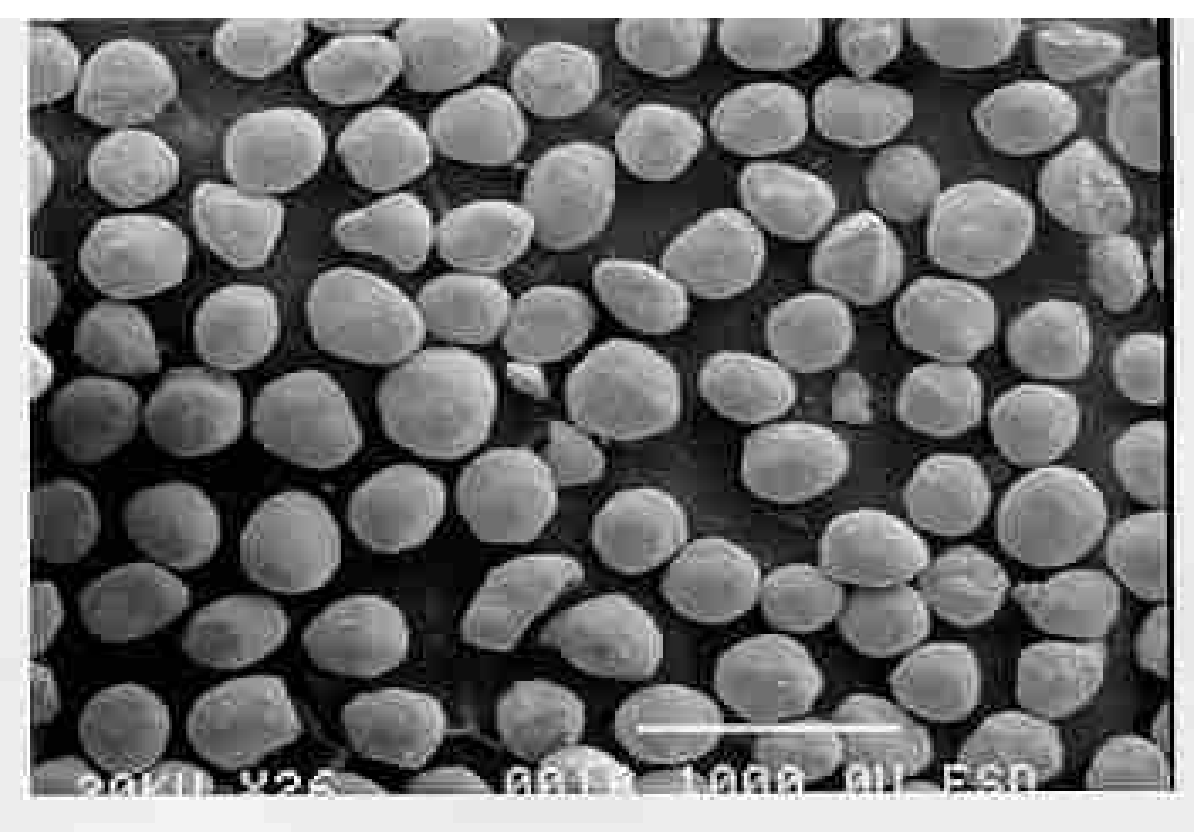

Fig. 7.6. SEM photomicrograph of CST collected from near the top of the column just before unloading.

\subsection{INTERACTION OF HYDROGEN PEROXIDE WITH CST}

During numerous tests with CST, from batch tests to small- and large-column tests, and during the analysis of peroxide using permanganate titrations, it was observed that titanium was being leached by hydrogen peroxide. It was later confirmed by inductively coupled plasma (ICP) analysis of the solutions that titanium was extracted from the CST by hydrogen peroxide. 


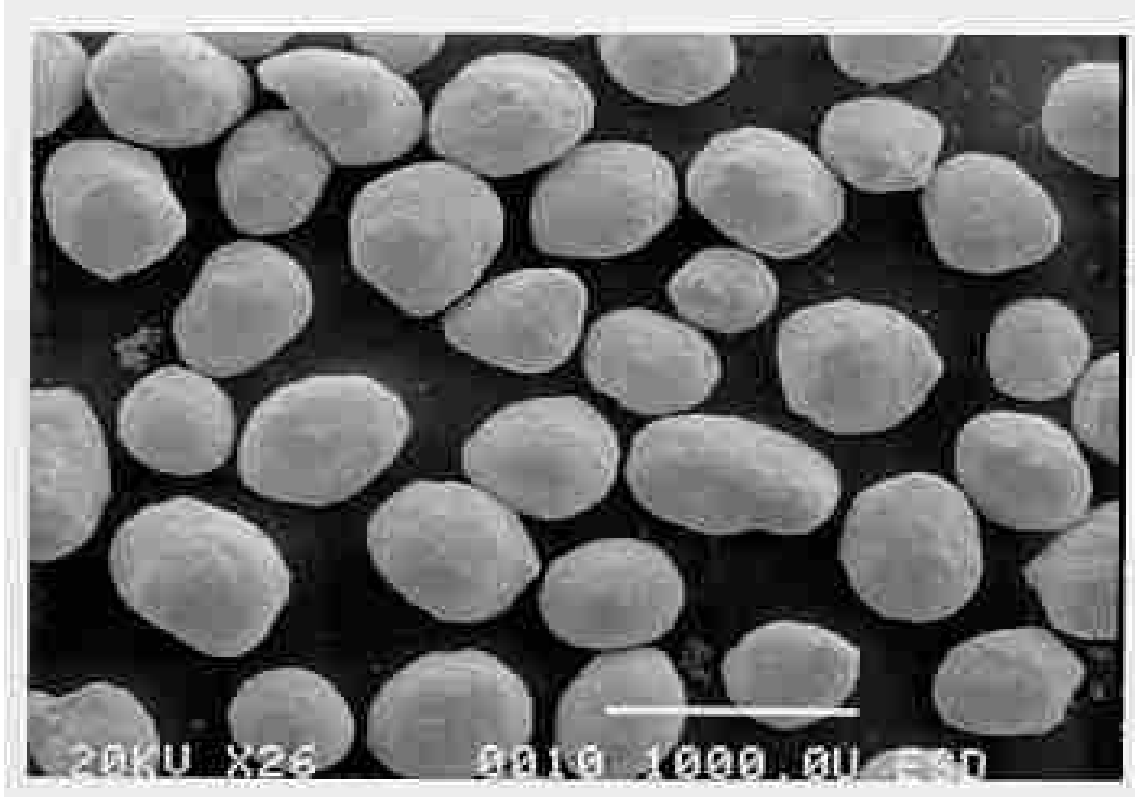

Fig. 7.7. SEM photomicrograph of CST collected from the bottom of the column just before unloading.

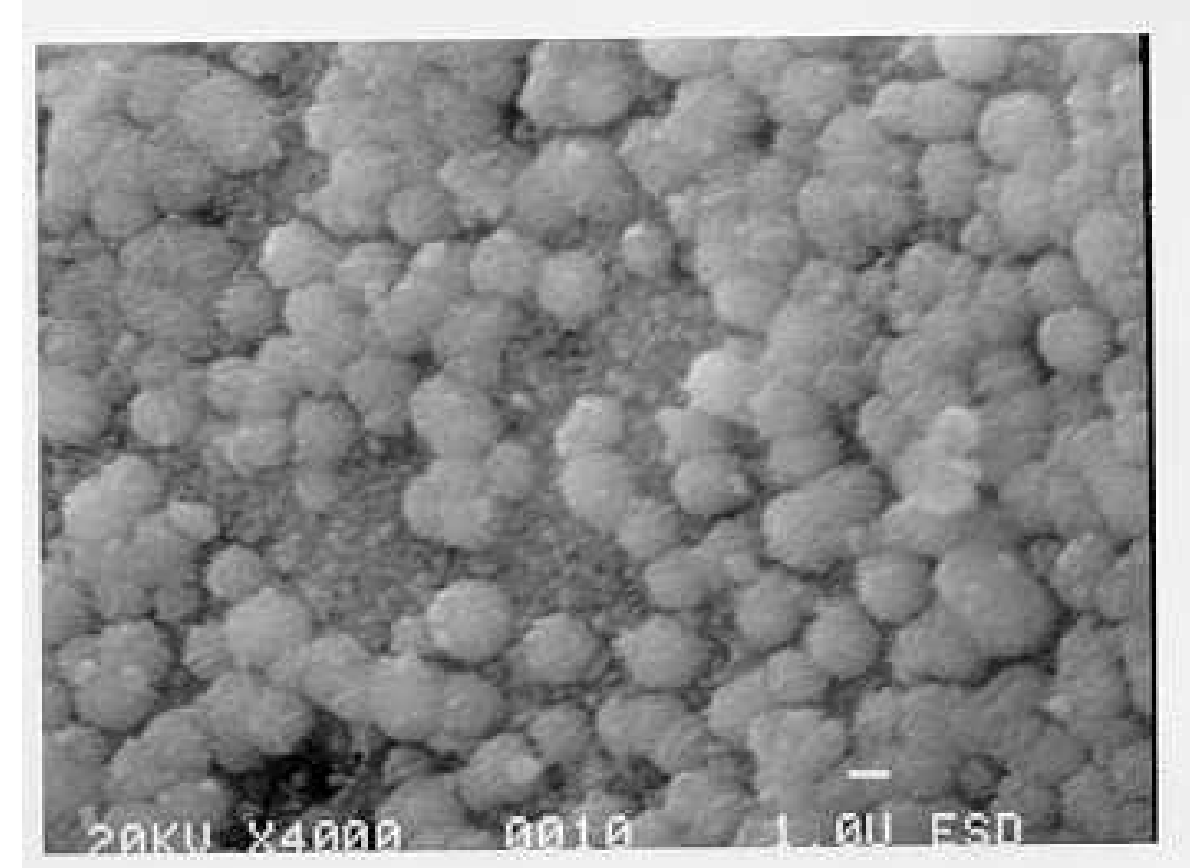

Fig. 7.8. SEM photomicrograph of precipitate nodules containing aluminum and silica on the surface of CST collected from the bottom of the column. 
This observation is very consistent with the known properties and ability of hydrogen peroxide to efficiently complex a large group of metals that can be solubilized and stabilized for short periods of time in alkaline solution. Hydrogen peroxide is a diprotic acid that is entirely ionized in the $2 M$ caustic solutions and forms peroxy complexes as the dianion $\left(\mathrm{O}_{2}{ }^{2-}\right)$ with metals such as Cr, U, Mo, V, W, Hf, Th, Ti, and Ta. Peroxide forms metal complexes with more-favorable formation constants in acid, as compared with bases; however, the formation constants in bases are sufficiently large such as to extract and retain metals in solution.

Aqueous solutions of hydrogen peroxide alone can even solubilize pure metals such as elemental tungsten. Hydrogen peroxide solutions are able to produce leachates loaded with as much as $400 \mathrm{gm} / \mathrm{L}$ of tungsten. In the case in which metals such as those listed previously are in a crystal lattice or even part of an amorphous phase, the interaction of the peroxide dianion, which is rich in bonding electrons, can form complexes with these metals and move them into solution. The vacancy left behind weakens the lattice, further contributing to the extraction of adjacent metals; similarly, in amorphous material, a larger specific surface becomes exposed to the peroxideladened solution.

Upon considering the interaction of hydrogen peroxide with titanium, a reaction may be written to describe the formation of the pertitanate anion, which can remain stable in the basic simulant for a limited period of time. The following reaction in alkaline solution depicts the complexation of the pertitanyl cation $\left(\mathrm{TiO}_{2}{ }^{2+}\right)$ by hydrogen peroxide to form the anion:

$\mathrm{TiO}_{2}{ }^{2+}+3 \mathrm{H}_{2} \mathrm{O}_{2}+6 \mathrm{OH}^{-}=\mathrm{Ti}\left(\mathrm{O}_{2}\right)_{4}^{4-}+6 \mathrm{H}_{2} \mathrm{O}$.

One may continue to write similar complexes with many of the metals (previously listed) with which peroxide may complex, as outlined in the peroxygen literature. In fact, the presence of titanium was initially most evident during the titration of peroxide with standardized potassium permanganate titrant, a reaction that must take place in sulfuric acid solution. In acid containing sulfate, the well-known bright yellow color of the pertitanyl sulfate complex $\left[\mathrm{TiO}_{2}\left(\mathrm{SO}_{4}\right)_{2}\right]^{2-}$ was nearly always present and was the first hint that we should analyze for this metal. This complex absorbs at $400 \mathrm{~nm}$ and is used to detect quantities as low as 1-2 ppm peroxide in an analytical method based upon its use.

Following a gas-generation test in which $0.70 \mathrm{wt} \%$ peroxide was used in simulant with a 5:1 ratio of simulant to CST (CST-Gas no. 14), an aliquot of the final solution was analyzed after $25 \mathrm{~h}$ using ICP analysis for 30 elements. A blank containing only simulant at the same ratio was also run over $25 \mathrm{~h}$ and analyzed. The leachate solution was found to contain $74.1 \mathrm{mg} / \mathrm{L}$ titanium; the blank contained $2.6 \mathrm{mg} / \mathrm{L}$ titanium. The concentration of hydrogen peroxide used was much higher than the concentration that would be expected in a column because of radiolysis, and at the lower concentrations, titanium leaching would be less important. An analysis of the effluent solution exiting the tall column is still pending, and results will be reported when available.

Samples of the CST were tested using a thermal gravimetric analyzer (TGA), and the CST was found to contain up to $2.4 \%$ hydrogen peroxide. In tests in which the CST was loaded with highconcentration hydrogen peroxide solution (3-4 wt \%), the CST retained the peroxide after being washed, filtered, and dried. Many days after drying, the CST could be added to an acidified 
solution, which caused the peroxide to be slowly released, as determined by titration using standardized potassium permanganate solution. A small sample of CST was soaked in nitritefree simulant and hydrogen peroxide for $24 \mathrm{~h}$. The peroxide-loaded CST was then rinsed with fresh simulant and air dried. About $177 \mathrm{mg}$ of dried CST was placed in a Harrop model ST-736 differential thermal analyzer (DTA)-TGA. Nitrogen at a rate of $100 \mathrm{~cm}^{3} / \mathrm{m}$ was passed over the sample during the DTA-TGA experiment. The sample was heated to $300^{\circ} \mathrm{C}$ at a rate of $120^{\circ} \mathrm{C} / \mathrm{h}$. While the treated sample was heated to $100^{\circ} \mathrm{C}$, the sample lost $2.4 \mathrm{mg}$ of water. The DTA results indicated that endothermic reactions occurred at 200 and $220^{\circ} \mathrm{C}$. During these reactions, the sample lost $4.3 \mathrm{mg}$. The reactions are probably caused by the release of absorbed peroxide. If so, then $2.4 \mathrm{wt} \%$ of the original treated sample was chemically bounded peroxide.

There is little doubt that hydrogen peroxide can complex and extract certain metallic components of the CST. This early speculation at ORNL (before any testing) has been recently confirmed. A hydrogen peroxide intermediate will be formed from water and/or nitrate in a high radiation field during actual use of CST at SRS, but its concentration is expected to be low. Nevertheless, the potential consequences of hydrogen peroxide in the solution are worth considering:

1. Peroxide can load on the CST. Which sites on the CST are taken up or bridged by the peroxide compared with those taking up cesium, and can this affect the loading capacity?

2. Will the ability of the peroxide to remove certain leachable metals from the CST affect the short-term physical properties of the CST?

3. Evidence exists that the solubilized peroxide-metal complexes decompose with time, allowing the metals to hydrolyze and precipitate as solids; can such solids present long-term problems associated with buildup?

\subsection{BED-LOAD DISTRIBUTION}

Discussions have been held between the U.S. Department of Energy technical team and UOP on the impact of the deep bed on sorbent stability. ${ }^{9}$ The physical investigation of the sorbent beads from the tall-column test taken from bottom and midway up the column showed no physical degradation. Photomicrographs of the beads show them to be uniform and equivalent to new beads after months of operation. Pictures and additional discussions are given in Sect. 7.2. This was not unexpected because the sorbent is an inorganic material, which historically has been shown to be strong.

The forces on the particles at the base of the column are determined by the weight of the sorbent, the supernatant feed, and the pressure drop. The weight of the sorbent follows a force vector, which is known as the angle of repose. The angle of repose for spherical beads such as CST is low, much as one would see in trying to build a pile of marbles in an unconfined area. Therefore, the side of the column carries the force, not the beads at the base of the column.

The suppliers of the sorbent provided a more rigorous description of the expected bead behavior, which is provided in the following paragraphs. This covers both the 3 -in.-diam column tested and an extrapolation of expected results for the 60 -in.-diam column. There is some experience 
with larger columns. For example, an ion-exchange system, used for aqueous ion exchange, which employs beds of 25-ft depth and 38-in. diam containing zeolite beads made in a process similar to the IONSIV® IE-911 beads, has been operated commercially.

The axial stresses in a granular bed of solids in a downflow column are the result of gravity loading on the solids, buoyant forces of the fluid, and fluid frictional drag forces caused by pressure drop and frictional forces of the granular solids against the walls of the vessel. The gravity forces and fluid frictional forces act on the solids as a body force distributed over the volume of solids in the column. As the body forces push on the solids, the solids create a lateral pressure against the wall of the column. The downward body forces are resisted by the friction of the solids against the wall of the column.

Figures 7.9 and 7.10 illustrate the equilibrium stresses for a bed of solids in a cylindrical vessel subjected to an effective density loading with a shear force reaction at the wall. The effective density is a result of both gravity weight loads and fluid frictional pressure drop per unit length. The radial stress against the wall of the column is related to the axial stress in the column. The vendor has developed a model that has expanded the theory to allow the theoretical calculation from the frictional characteristics of the granular material. The data required include the coefficient of friction of solids on solids and the coefficient of friction of solids on the vessel wall. The coefficient of friction of solids on solids is related to the angle of repose of the material.

The effect of wall friction limits the maximum stress at the bottom of the column to a value known as the "Janssen limit." The limiting axial stress is equal to the effective density times the hydraulic diameter of the column divided by a value four times the coefficient of wall friction times the Janssen $\mathrm{K}$ value. The axial stress asymptotically reaches the limit as a function of depth divided by column diameter.

Although specific values of solids and wall friction are not available, typical values (based on zeolite adsorbents made in similar manufacturing processes) were assumed to develop some plots and numerical values. MATHCAD ${ }^{\mathrm{TM}}$ plots (Figs. 7.9 and 7.10) illustrate the difference between the axial stress (in pounds per square inch) in a 60-in.-diam column and a 3-in.-diam column, both with $16 \mathrm{ft}$ of packed depth. The figures are based on a solids bulk density of $65 \mathrm{lb} / \mathrm{ft}^{3}$, a liquid specific gravity of 1.25 , a packed voidage of 0.35 , and a frictional pressure drop of $7.5 \mathrm{psi} / 16 \mathrm{ft}$. Figure 7.9 presents data for the 60 -in.-diam column, and 7.10 , for the 3 -in.-diam column. The axial stress in the 60-in.-diam column is 17.6 times greater than that in the 3-in.-diam column, as a result of the greater wall friction in the smaller-diameter column.

The experience of UOP with axial flow in packed columns is that the axial stresses resulting from static gravity loads and pressure drop are typically well below the static strength of the solids. Therefore, even though the bed stresses are much lower in the 3-in.-diam column, it is not anticipated the increased stress in the commercial-size column will be great enough to be a problem. A conservative estimate of the maximum stress at the bottom of a column, neglecting wall friction, is simply the bulk density (corrected for buoyancy) times the height plus the total column pressure drop. 


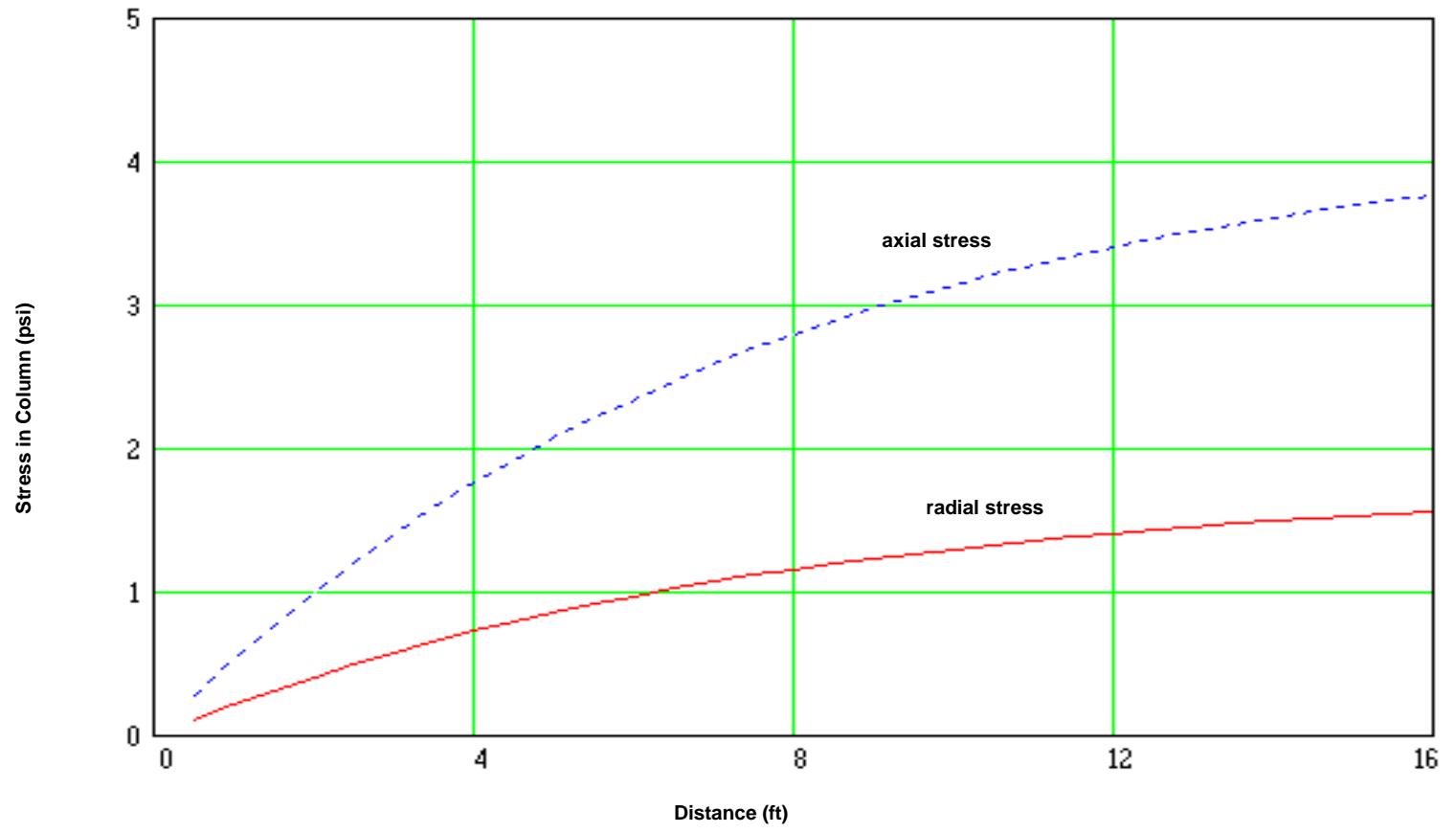

Fig. 7.9. Stress variation in 60-in.-diam column.

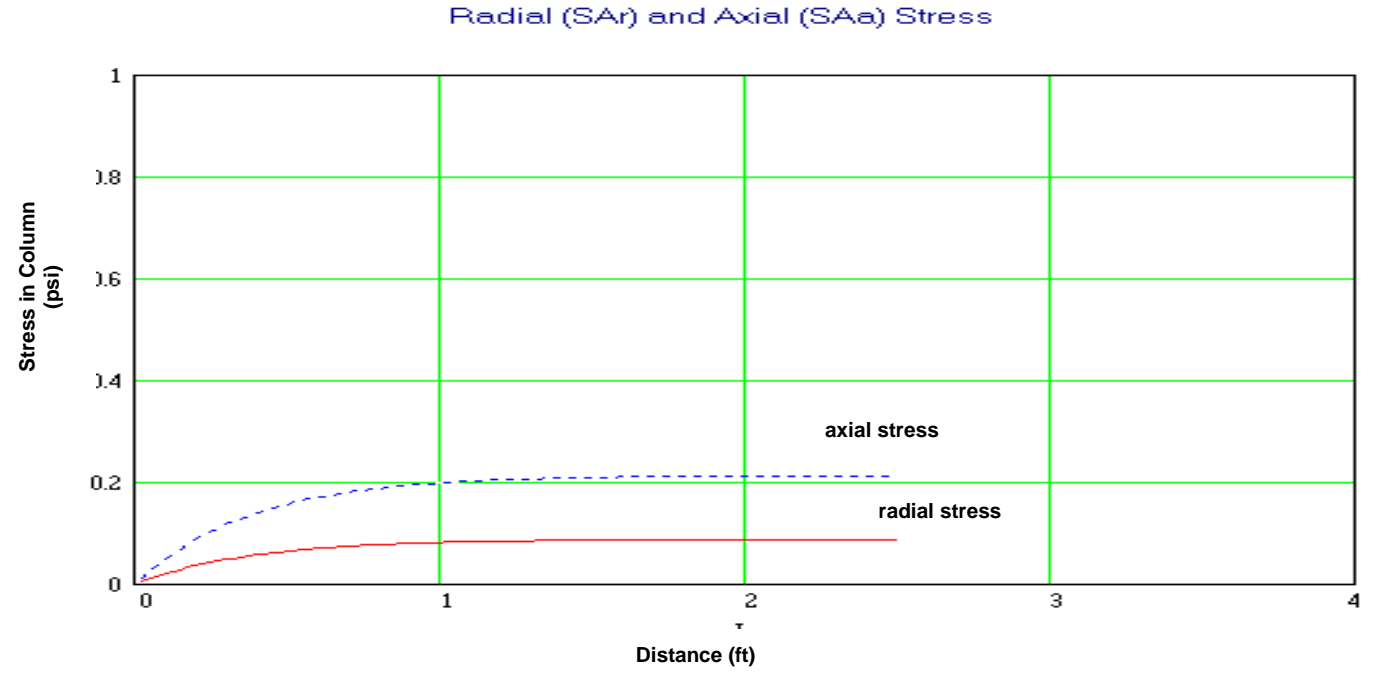

Fig 7.10. Stress variation in 3-in.-diam column [PC25]. 


\section{CONCLUSIONS AND RECOMMENDATIONS}

This study was based on a 16-ft-tall bed column design with a superficial velocity of $4.1 \mathrm{~cm} / \mathrm{min}$. If the optimal design proves to be different, changes in mass transfer, heat transfer, and hydraulics will need to be evaluated.

CST was easily sluiced to and from the ion-exchange column using water and air. The asreceived CST was slightly acidic and contained fines that were generated during shipping. The CST was added to the column in three batches, and the column was backwashed after each batch to remove any fines generated during sluicing. The column was backwashed with tap water at flow rates up to $1.2 \mathrm{~L} / \mathrm{min}$ after the first and second batches of CST were added to the column, and at up to $0.6 \mathrm{~L} / \mathrm{min}$ after the third batch was added. The CST bed was expanded by at least $50 \%$ during the first and second backwashes, but by only $20 \%$ during the third because of a lack of free space in the column. Expanding the bed during backwashing segregated the particles, small at the top and large at the bottom. It is recommended that solids-handling vessels such as the solids-loading tanks be designed to reduce the generation of fines.

Hydraulic tests were conducted to obtain data useful for column operation. Pressure drop through the column and across the Johnson screen and the effect of flow rate on pressure drop were measured. The column pressure drops for the first four tests ranged from 17 to $23 \mathrm{psig}$. The pressure drop at the top of the bed, where a layer of fines and fragments of CST and other materials existed, accounted for 60 to $70 \%$ of the pressure drop. After the bed was expanded to redistribute these layers, the pressure drop stabilized in the 7-psig range at $5-\mathrm{cm} / \mathrm{min}$ superficial velocity. The pressure drop across the column calculated by the Blake-Kozeny equation $(7.75 \mathrm{psig})$ is in good agreement with the measured 7.4-psig pressure drop in hydraulic test 6 . The pressure drops in the bed at the nominal flow rate were relatively constant and varied from 0.35 to $0.45 \mathrm{psig} / \mathrm{ft}$. The pressure drop across the Johnson screen remained constant throughout the six tests, ranging from 0.45 to 0.55 psig. No channeling was detected. The pressure drop across the Johnson screen did not increase, indicating no accumulation on the screen.

The column handled gas generation without apparent hydraulic or operational problems. Small quantities of gas accumulated in the column but, after building up, escaped from the column with the effluent. The column was able to expel gas even at generation rates 16 times the maximum expected during SRS operations. The bed did not expand. This finding suggests that in the flowing system, gas bubbles remain small and move with the liquid rather than attaching to and blanketing the CST. This reaction is beneficial with respect to heat transfer and adsorption performance, but this behavior needs to be confirmed by experimental investigations of heat and mass transfer. The bed pressure drop increased by a factor of 2 to 2.5 with gas in the bed. This pressure-drop increase corresponds to a gas void of about $7 \%$ from the Blake-Rozeny equation. The pressure drop doubled when gas was being generated in the bed. After an inventory of gas had built up in the column, the pressure drop was relatively insensitive to the gas-generation rate.

Upon shutdown, part of the gas inventory, amounting to about $3 \%$ of bed volume, disengaged from the bed and bubbled in streams from the top of the bed. The axial gas distribution remains 
to be determined. An acoustic probe may be useful for determining the axial distribution of the gas in the bed.

Because hydrogen peroxide is a radiolysis intermediate, peroxide chemistry may be relevant to the environment to which the CST will be subjected in actual supernatant. However, the radiolytic hydrogen peroxide concentration will be much lower than the concentrations used in these tests. Peroxide leaching of metals from the CST was observed. Titanium stabilizes hydrogen peroxide.

Solids precipitates containing aluminum and silicon occurred at the bottom of the column in a stagnant area below the Johnson screen, where residual water was known to have been present during the early tests. Conditions leading to precipitation should be avoided.

Unloading the CST from the column with water and pressurized air worked well and should scale directly to the larger-diameter column. The CST slurry flowed easily under a moderate pressure. Residual CST remained at the bottom of the column below the unloading dip tube, which is consistent with experience with the Melton Valley Ion Exchange column.

The CST appears to have remained intact, with little breakage or attrition after 2 months in the column. Some constituents were apparently leached from the CST by the simulant. Potential impacts of this leaching on performance should be investigated.

In addition to catalyzing the hydrogen peroxide decomposition reaction, CST also adsorbs hydrogen peroxide. Thus, using hydrogen peroxide not only simulated gas generation but also allowed simulation of movement of the gas-generation front as one would encounter it due to cesium loading in an actual system. 


\section{ACKNOWLEDGMENTS}

This work was funded jointly by the Tanks Focus Area and the Savannah River Salt Disposition Project. The design and fabrication of the column were completed with the assistance of the Plant and Equipment Division of the Oak Ridge National Laboratory. The planning and execution of the work was a joint effort, and the technical and programmatic staff at Savannah River Site provided much helpful input and technical support. 


\section{REFERENCES}

1. Paul Rutland, Thermal and Hydraulic Properties, "Sect. 10.2: Large Column Operation," Technical Task Request HLW-SDT-TTR-99-10.0, Rev. 1, Westinghouse Savannah River Company, Aiken, S.C., March 3, 1999.

2. S. F. Piccolo, Science and Technology Roadmap for CST Non-Elutable Ion Exchange, HLW-SDT-980165, Rev. 0, Westinghouse Savannah River Company, Aiken, S.C., Dec. 14, 1998.

3. High Level Waste Salt Disposition Systems Engineering Team, Applied Technology Integration Scope of Work Matrix for Decision Making, HLW-SDT-99-0009, Rev. 0, Westinghouse Savannah River Company, Aiken, S.C., Jan. 22, 1999.

4. S. Beck et al., Bases, Assumptions, and Results of the Flowsheet Calculations for the Short List Salt Disposition Alternatives, WSRC-RP-98-00168, Rev. 1, Westinghouse Savannah River Company, Aiken, S.C., Oct. 29, 1998.

5. $\quad$ R. A. Jacobs, Estimate of Gas Generation in Fully Loaded CST Column, HLW-SDT-990248, Westinghouse Savannah River Company, Aiken, S.C., Aug. 18, 1999.

6. D. D. Walker, Preparation of Simulated Waste Solutions, WSRC-TR-99-00116, Westinghouse Savannah River Company, Aiken, S.C., Apr. 15, 1999.

7. J. F. Walker, Jr., P. A. Taylor, R. L. Cummins, B. S. Evans, and S. D. Heath, Cesium Removal Demonstration Utilizing Crystalline Silicotitinate Sorbent for Processing Melton Valley Storage Tank Supernate: Final Report, ORNL/TM-13503, Oak Ridge National Laboratory, Oak Ridge, Tenn., March 1998.

8. R. B. Bird, W. E. Stewart, and E. N. Lightfoot, Transport Phenomena, John Wiley \& Sons, New York, 1960, p. 199.

9. J. W. Koves, UOP LLC, Des Plaines, Ill., Letter entitled "Axial Solids Bed Stresses in a Packed Downflow Column” to C. P. McGinnis, Oak Ridge National Laboratory, Oak Ridge, Tenn., and J. D. Sherman, UOP LLC, Des Plaines, Ill., September 21, 1999. 
Appendix A

EQUIPMENT AND INSTRUMENTATION 


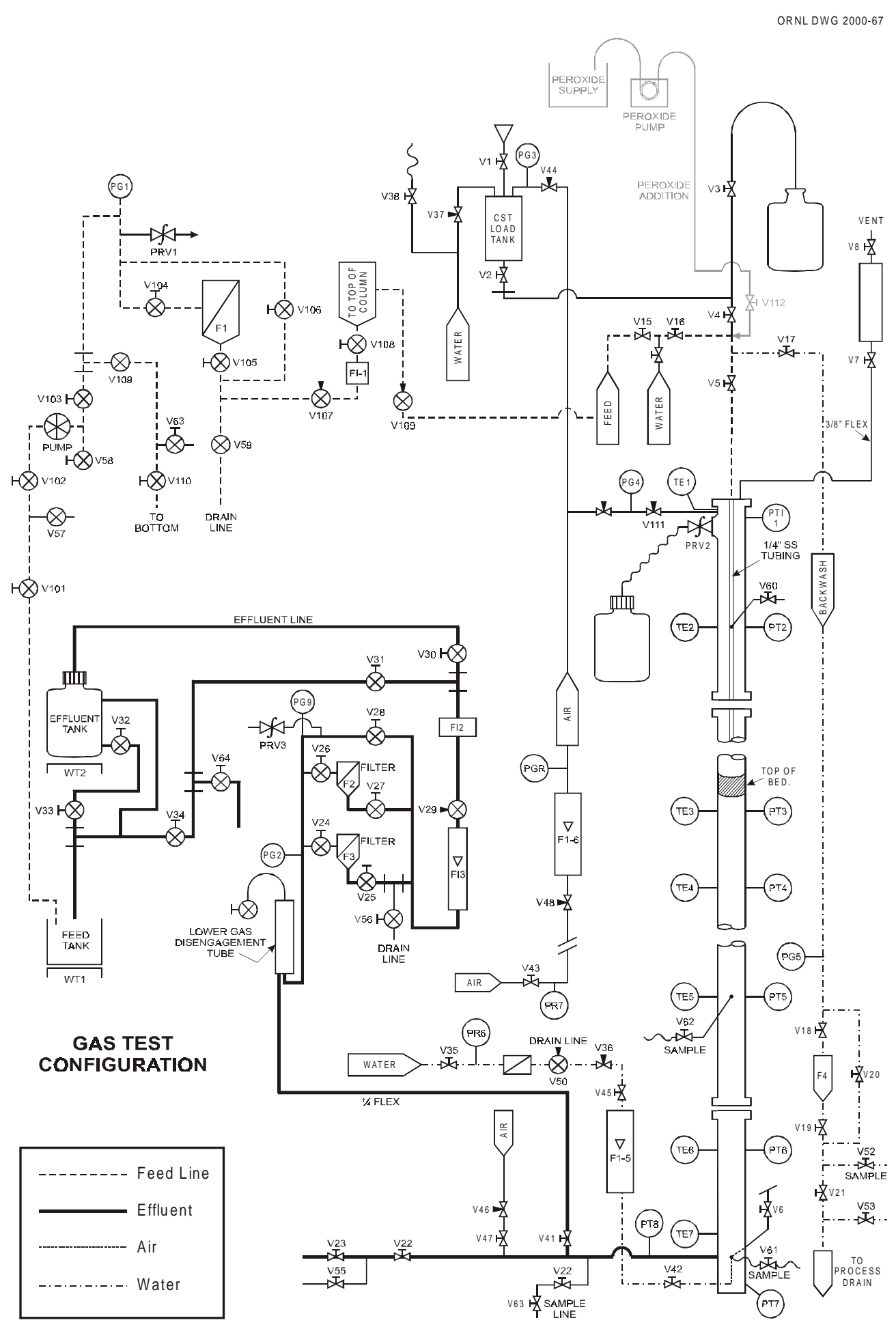

Fig A.1. Process and instrumentation diagram showing the gas test configuration. 
Table A.1 Descriptions of equipment and instrumentation

\begin{tabular}{|c|c|c|c|c|}
\hline ID no. & Description & Specifications & $\begin{array}{c}\text { Manufacturer/ } \\
\text { part no. }\end{array}$ & Comments \\
\hline $\begin{array}{l}\text { Pump head for feed } \\
\text { pump }\end{array}$ & $\begin{array}{l}\text { Magnetic gear, } \\
\text { high-precision } \\
\text { programmable pump }\end{array}$ & $\begin{array}{l}\text { Maximum drive of } \\
3400 \mathrm{rpm}, \text { flow } \\
\text { range of } 10-4500 \\
\mathrm{~mL} / \mathrm{min}, \mathrm{max} . \\
\text { pressure of } 100 \mathrm{psi}, \\
110 \mathrm{Vac}, 4-20 \mathrm{~mA} \\
\text { Maximum flow rate of } \\
2100 \mathrm{~L} / \mathrm{min}, \mathrm{max} . \\
\text { pressure of } 110 \mathrm{psi}\end{array}$ & $\begin{array}{l}\text { Expert Sci-Log } \\
\text { VWR 54845-668 }\end{array}$ & $\begin{array}{l}\text { Proven in on-site } \\
\text { testing and desired } \\
\text { control and precision }\end{array}$ \\
\hline Peroxide pump & $\begin{array}{l}\text { Variable speed } \\
\text { peristaltic } 115 \mathrm{Vac}\end{array}$ & & $\begin{array}{l}\text { Master flex model } \\
17518-00\end{array}$ & $\begin{array}{l}\text { Previously used } \\
\text { successfully in small } \\
\text { volume dispensing }\end{array}$ \\
\hline $\begin{array}{l}\text { Tanks } \\
\text { Feed Tank, Effluent } \\
\text { tank } \\
\text { Column body, } \\
\text { unloading tube }\end{array}$ & $\begin{array}{l}\text { Carboy tanks, } 30 \text { gal, } \\
\text { polyethylene } \\
\text { PVC Pipe } \\
\text { 1- and 3-in. diameter, } \\
\text { Harvel clear PVC } \\
\text { schedule } 40\end{array}$ & & VWR 60455-184 & $\begin{array}{l}\text { Compatible with } \\
\text { caustic and cost- } \\
\text { effective }\end{array}$ \\
\hline Valves & & & & \\
\hline $\begin{array}{l}(\mathrm{V} 15-28,52-53,55, \\
56,59,104-106)\end{array}$ & $\begin{array}{l}3 / 4 \text { in. SS ball valves, } \\
\text { Apollo type } 300 \mathrm{SS} \text {, } \\
\text { Teflon seats }\end{array}$ & $\begin{array}{l}150 \text { psi, screwed ends, } \\
\text { Swagelok connections }\end{array}$ & 96-104-01 & $\begin{array}{l}\text { Compatible Swagelok } \\
\text { fit }\end{array}$ \\
\hline $\begin{array}{l}\text { V } 30,31,34,38, \\
40,60-63,64,101, \\
102-103,108-110, \\
112\end{array}$ & 1/4-in. SS ball valves & $\mathrm{SS}, 1 / 4$ in. & $\mathrm{P} \& \mathrm{E}$ stock & \\
\hline $\begin{array}{l}\text { V } 29,39,41,44, \\
46,47,107,109, \\
111\end{array}$ & 1/4-in. SS needle valves & $\mathrm{SS}, 1 / 4$ in. & & \\
\hline V 7, V 8 & 3/8-in. SS ball valve & $\mathrm{SS}, 3 / 8$ in. & P\&E stock & \\
\hline V 48, V 50 & $\begin{array}{l}3 / 8 \text {-in. SS needle } \\
\text { valve }\end{array}$ & $\mathrm{SS}, 3 / 8$ in. & P\&E stock & \\
\hline V32, V33 & 5/8-in. SS ball & $\mathrm{SS}, 5 / 8$ in. & P\&E stock & \\
\hline V1 & 2-in. PVC & PVC 2 in. & P\&E stock & \\
\hline $\mathrm{V} 2, \mathrm{~V} 6$ & 1-in. PVC & PVC 1 in. & P\&E stock & \\
\hline V5 & 1-in. SS ball & SS 1 in. & P\&E stock & \\
\hline $3 / 4$ in. SS tubing & & $\mathrm{SS}, 3 / 4 \mathrm{in}$. & P\&E stock & $\begin{array}{l}\text { Best option for rigidity } \\
\text { and Swagelok fit }\end{array}$ \\
\hline $\begin{array}{l}\text { 3/4-in. OD } \\
\text { connections }\end{array}$ & & $\mathrm{SS}, 3 / 4$ in. & P\&E stock & \\
\hline
\end{tabular}


Table A.1 Descriptions of equipment and instrumentation

\begin{tabular}{|c|c|c|c|c|}
\hline ID no. & Description & Specifications & $\begin{array}{c}\text { Manufacturer/ } \\
\text { part no. }\end{array}$ & Comments \\
\hline Flanges & 3-in. PVC flange & $\begin{array}{l}\text { Socket weld, } 150 \text { psi, } \\
\text { sch. } 80\end{array}$ & $851-030$ & $\begin{array}{l}\text { Compatible with } \\
\text { simulant }\end{array}$ \\
\hline Gaskets & Cut-to-fit Viton gaskets & Standard 1/4-in. Viton & & \\
\hline $\begin{array}{l}\text { Flow transmitter } \\
(\mathrm{FL} 1, \mathrm{FL} 2)\end{array}$ & $\begin{array}{l}\text { Cole-Parmer, turbine } \\
\text { flowmeter }\end{array}$ & $\begin{array}{l}\text { 4- to } 20 \text {-mA, single- } \\
\text { channel display, } \\
115 / 230 \text { Vac, 1/4-in. } \\
\text { NPT (M), 710-psi } \\
\text { max pressure, 13-psi } \\
\text { max. pressure drop, } \\
0.07 \text {-to } 4.5-\mathrm{L} / \mathrm{min} \text { flow } \\
\text { rate }\end{array}$ & $\begin{array}{l}\text { P-32919-30 } \\
\text { P-32919-00 } \\
\text { P-32929-90 }\end{array}$ & $\begin{array}{l}\text { Accuracy } \pm 1 \% \text {, } \\
\text { acceptable viscosity } \\
\text { range, repeatability, } \\
\text { and particulate size }\end{array}$ \\
\hline $\begin{array}{l}\text { Filters } \\
(\mathrm{F} 1,2,3,4)\end{array}$ & $\begin{array}{l}\text { In-line bag filters with } \\
\text { housing }\end{array}$ & $\begin{array}{l}\text { Polypropylene } 1-, 5-\text {, } \\
\text { and } 10-\mu \mathrm{m} \text { bags, SS } \\
\text { ring, } 4 \times 8 \text { in., caustic } \\
\text { compatible, minimal } \\
\text { pressure drop }\end{array}$ & $\begin{array}{l}\text { Hayward- } \\
\text { Afco/American felt } \\
\text { and filter }\end{array}$ & $\begin{array}{l}\text { Used successfully on } \\
\text { cold test loop }\end{array}$ \\
\hline $\begin{array}{l}\text { Johnson screen } \\
\text { (JS1) }\end{array}$ & $\begin{array}{l}\text { Johnson screen for } \\
\text { bottom of column }\end{array}$ & $\begin{array}{l}\text { 3/4-in. NPT, } 2 \text { in. } \times \\
1-3 / 16 \text { in. , optimum } \\
\text { spacing } 6 \text { in., max. } 4.0 \\
\text { gal/min, max. } \\
\text { backwash } 6.5 \text { gal/min, } \\
\text { 300-psi collapse } \\
\text { pressure, 200-psi } \\
\text { burst pressure }\end{array}$ & US Filter $100 \mathrm{~N}$ & \\
\hline $\begin{array}{l}\text { Pressure gauges } \\
(\mathrm{PG}-1,2,3,4,5,6,7,8)\end{array}$ & $\begin{array}{l}\text { Pressure gauges and/or } \\
\text { regulators }\end{array}$ & $\begin{array}{l}0-100 \text { psi, back or } \\
\text { rear mount } 1 / 4 \text { in. } \\
\text { NPT }\end{array}$ & P\&E contract supply & \\
\hline $\begin{array}{l}\text { Scales } \\
\text { (WT-1) } \\
\text { (WT-2) }\end{array}$ & $\begin{array}{l}\text { Digital weight meter } \\
\text { Digital weight meter }\end{array}$ & $\begin{array}{l}0 \text { to } 500-\mathrm{lb} \text { capacity } \\
0 \text { to } 500-\mathrm{lb} \text { capacity }\end{array}$ & $\begin{array}{l}\text { Electroscale } \\
\text { Model LC2424 } \\
\text { Circuits \& Systems, } \\
\text { Inc., Model SX-501 } \\
\end{array}$ & \\
\hline $\begin{array}{l}\text { Pressure } \\
\text { transducers } \\
(\mathrm{PT} 1-8)\end{array}$ & See Table A. 2 & & & \\
\hline $\begin{array}{l}\text { Thermocouples } \\
\text { (TE-1,2,3,5,6,7) }\end{array}$ & $\begin{array}{l}\text { See Table A.3 } \\
\text { Type J thermocouples }\end{array}$ & $\begin{array}{l}\text { Rated to } 400^{\circ} \mathrm{F} \text {, } \\
\text { grounded junction, } \\
\text { PFA coating, caustic } \\
\text { compatible, quick- } \\
\text { disconnect }\end{array}$ & ICSS-11-GG-12-PFA & \\
\hline $\begin{array}{l}\text { Pressure relief } \\
\text { valves }\end{array}$ & & & & \\
\hline
\end{tabular}


Table A.1 Descriptions of equipment and instrumentation

\begin{tabular}{|l|l|l|l|l|}
\hline \multicolumn{1}{|c|}{ ID no. } & \multicolumn{1}{c|}{ Description } & Specifications & \multicolumn{1}{c|}{$\begin{array}{c}\text { Manufacturer/ } \\
\text { part no. }\end{array}$} & Comments \\
\hline (PRV-1,2,3) & $\begin{array}{l}\text { Hayward Industrial } \\
\text { 1-in. PVC pop-off valve }\end{array}$ & $\begin{array}{l}\text { 3/4-in., NPT, set at 70 } \\
\text { psi }\end{array}$ & & $\begin{array}{l}\text { Compatible with } \\
\text { caustic }\end{array}$ \\
\hline $\begin{array}{l}\text { Rotameters } \\
\text { FL-3,4,5) } \\
\text { See Table A.3 }\end{array}$ & & & & \\
\hline FL-6 & Air regulator rotameter & $0-6$ SCFM @ STP & P\&E contract supply & $\begin{array}{c}\text { Compatible with } \\
\text { system needs }\end{array}$ \\
\hline
\end{tabular}


Table A.2. Pressure instrumentation (gas test configuration, after 8/30/99)

\begin{tabular}{|c|c|c|c|c|c|c|c|c|}
\hline $\begin{array}{c}\text { Sensor } \\
\text { designation }\end{array}$ & Instrument type & Location & I\&C ID Number & Serial number & Manufacturer & Model no. & Description & Comments \\
\hline PT 1 & Pressure transducer & Column at $6 \mathrm{~m}$ & M084636 & $96156-3448$ & OMEGA & PX102-050GV & $0-50 \mathrm{psig}$ & \\
\hline PI 1 & Pressure indicator & Connects with PT 1 & M084495 & 8385496 & OMEGA & DP25-E-AR & & \\
\hline PT 2 & Pressure transducer & Column at $5 \mathrm{~m}$ & M084637 & $96156-3452$ & OMEGA & PX102-050GV & $0-50 \mathrm{psig}$ & \\
\hline PI 2 & Pressure indicator & Connects with PT 2 & M084496 & 8385499 & OMEGA & DP25-E-AR & & \\
\hline PT 3 & Pressure transducer & Column at $4 \mathrm{~m}$ & M084638 & $96156-3454$ & OMEGA & PX120-050 & $0-50$ psig & \\
\hline PI 3 & Pressure indicator & Connects with PT 3 & M084497 & 8385512 & OMEGA & DP25-E-AR & & \\
\hline PT 4 & Pressure transducer & Column at $3 \mathrm{~m}$ & M084641 & $96156-3444$ & OMEGA & PX102-050GV & $0-50$ psig & \\
\hline PI 4 & Pressure indicator & Connects with PT 4 & M084500 & 8385515 & OMEGA & DP25-E-AR & & $\begin{array}{l}\text { This indicator was } \\
\text { paired with PT6 } \\
\text { (M084639) prior to } \\
\text { gas tests }(8 / 30 / 99)\end{array}$ \\
\hline PT 5 & Pressure transducer & Column at $2 \mathrm{~m}$ & M084640 & $96156-3442$ & OMEGA & PX102-050GV & $0-50$ psig & \\
\hline PI 5 & Pressure indicator & Connects with PT 5 & M084498 & 8385483 & OMEGA & DP25-EAR & & \\
\hline PT 6 & Pressure transducer & Column at $1 \mathrm{~m}$ & M084639 & $96156-3438$ & OMEGA & PX102-050GV & $0-50 \mathrm{psig}$ & \\
\hline PI 6 & Pressure indicator & Connects with PT 6 & M084499 & 8385495 & OMEGA & DP25-E-AR & & $\begin{array}{l}\text { This indicator was } \\
\text { paired with PT4 } \\
\text { (M084641) prior to } \\
\text { gas tests }(8 / 30 / 99)\end{array}$ \\
\hline PT 7 & Pressure transducer & Column at $0 \mathrm{~m}$ & M084642 & $96156-3455$ & OMEGA & $\begin{array}{l}\text { PX102- } \\
\text { 050GV }\end{array}$ & $0-50$ psig & \\
\hline PI 7 & Pressure indicator & Connects with PT 7 & M084501 & 8385526 & OMEGA & DP25-E-AR & & \\
\hline PT 8 & Pressure transducer & $\begin{array}{l}\text { Downstream of Johnson } \\
\text { screen }\end{array}$ & M084643 & $96156-3458$ & OMEGA & $\begin{array}{l}\text { PX102- } \\
\text { 050GV }\end{array}$ & $0-50$ psig & \\
\hline PI 8 & Pressure indicator & Connects with PT 8 & M084502 & 8385543 & OMEGA & DP25-E-AR & & \\
\hline
\end{tabular}


Table A.3. Temperature, flow, and weight instruments

\begin{tabular}{|c|c|c|c|c|c|c|c|}
\hline Sensor designator & Instrument type & I\&C ID no. & Serial no. & Manuf. & Model no. & Description & Comments \\
\hline TE-1 & Type J thermocouple & M084646 & N/A & OMEGA & ICSS-116G-12-PFA & $5-50^{\circ} \mathrm{C}$ & \\
\hline TE-2 & Type J thermocouple & M084647 & N/A & OMEGA & ICSS-116G-12-PFA & $5-50^{\circ} \mathrm{C}$ & $\begin{array}{l}\text { Replaced with } 1 / 8 \text {-in. SS sheathed } \\
\text { Type J }\end{array}$ \\
\hline TE-3 & Type $\mathrm{J}$ thermocouple & M084645 & N/A & OMEGA & ICSS-116G-12-PFA & $5-50^{\circ} \mathrm{C}$ & \\
\hline TE-4 & Type $\mathrm{J}$ thermocouple & M084644 & N/A & OMEGA & ICSS-116G-12-PFA & $5-50^{\circ} \mathrm{C}$ & \\
\hline TE-5 & Type $\mathrm{J}$ thermocouple & M084649 & N/A & OMEGA & ICSS-116G-12-PFA & $5-50^{\circ} \mathrm{C}$ & \\
\hline TE-6 & Type J thermocouple & M084648 & N/A & OMEGA & ICSS-116G-12-PFA & $5-50^{\circ} \mathrm{C}$ & \\
\hline TE-7 & Type J thermocouple & M084650 & N/A & OMEGA & ICSS-116G-12-PFA & $5-50^{\circ} \mathrm{C}$ & \\
\hline TE-Feed & Type K, class 1 & & 06-9780015 & & & & UCGP, 055B929247-X06B \\
\hline FL 1 & Flowmeter & M090601 & None & Cole-Parmer & $9-32919-000$ & Accuracy $\pm 1 \%$ & Calibrate with output noted \\
\hline FL 2 (Gas tests) & Flowmeter & & & Cole-Parmer & & Accuracy $\pm 1 \%$ & \\
\hline $\begin{array}{l}\text { FL-2 (Fl-3 during } \\
\text { gas tests) }\end{array}$ & Rotameter & M090613 & 42469-990106-006 & & $73313630-41 \mathrm{~W}$ & $0-0.5 \mathrm{gal} / \mathrm{min}$ & $\begin{array}{l}\text { Calibrated by weight within } 8 \% \text { full } \\
\text { scale (FS); uncertainty of Std } \pm 0.5 \% \\
\text { rdg }\end{array}$ \\
\hline $\begin{array}{l}\text { FL-4 (Backwash } \\
\text { test) }\end{array}$ & Rotameter & M090614 & None & Blue White Ind. & F-40375LN & $0-1 \mathrm{gal} / \mathrm{min}$ & $\begin{array}{l}\text { Calibrated by weight within } 9 \% \text { FS; } \\
\text { uncertainty of Std } \pm 0.5 \% \text { rdg }\end{array}$ \\
\hline FL (Backwash) & Rotameter & & & Blue White Ind. & F-40375LN & $0-1 \mathrm{gal} / \mathrm{min}$ & Used for backwash only \\
\hline FL-5 (Backwash) & Rotameter & M084635 & N/A & & F-40750LN-12 & $1-10 \mathrm{gal} / \mathrm{min}$ & \\
\hline Wt 1 & Weight scale & X151965 & 34731 & Electroscale & LC2424 & $0-500 \mathrm{lb}$ & $\begin{array}{l}\text { Standard weights = M076471; } \\
\text { The units were kg through hydralic } \\
\text { runs; lbs for gas tests }\end{array}$ \\
\hline Wt 2 & Weight scale & M089081 & $5098 \mathrm{~A}$ & $\begin{array}{l}\text { Circuits \& } \\
\text { Systems, Inc. }\end{array}$ & SX-501 & $0-500 \mathrm{lb}$ & Standard weights $=$ M076471 \\
\hline Pump 1 & Pump & M084493/892738 & E300-192-0999 & Expert Sci-Log & $120-000-110$ & $0-4500 \mathrm{cc} / \mathrm{min}$ & \\
\hline
\end{tabular}


Appendix B

SOLIDS FORMATION 


\section{APPENDIX B. SOLIDS FORMATION}

The average simulant for these tests had a sodium concentration of 5.6 $M$. The dilution of simulant from a sodium concentration of $6.4 \mathrm{M}$ to $5.6 \mathrm{M}$ can result in the formation of additional solids due to a decrease in the hydroxide concentration. Hydroxide is related to the concentration of aluminum in solution by the following equation:

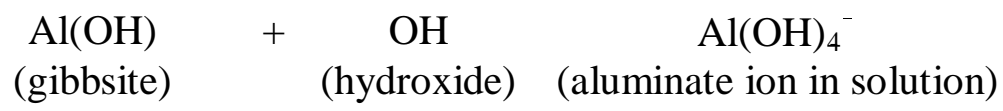

As the hydroxide concentration decreases due to dilution, the equilibrium shifts to the left and additional gibbsite would be formed. To avoid this formation of gibbsite, it is necessary to dilute with water plus sodium hydroxide to maintain the $\mathrm{OH}^{-}$concentration.

Table B.1 lists the species at equilibrium calculated for the "average" waste simulant with a sodium ion concentration of $6.4 \mathrm{M}$. The calculations were run using a computer routine described in refs. B.1 and B.2. No silicon-containing species were included in this calculation. Table B. 1 indicates that $3.07 \times 10^{-2}$ mol of $\mathrm{Al}(\mathrm{OH})_{3}$ solid should form for each liter of simulant. When the "average" waste simulant is diluted with water so that the sodium ion concentration is $5.6 \mathrm{M}$, the calculations indicate that $5.42 \times 10^{-2} \mathrm{~mol}$ of $\mathrm{Al}(\mathrm{OH})_{3}$ solid should form for every liter of solution. The results of this calculation are listed in Table B.2.

The increase in solid $\mathrm{Al}(\mathrm{OH})_{3}$ can be avoided by diluting the simulant that is $6.4 \mathrm{M}$ in sodium with water and sodium hydroxide. Table B.3 lists the calculation for a solution that is $5.6 M$ in sodium without additional precipitation of $\mathrm{Al}(\mathrm{OH})_{3}$. This dilution could be accomplished by adding $139.9 \mathrm{~g}(7.766 \mathrm{~mol})$ water and $7.479 \mathrm{~g}(0.187 \mathrm{~mol}) \mathrm{NaOH}$ to $889.5 \mathrm{~g}$ of simulant at $6.4 \mathrm{M}$ sodium ion to make $1.037 \mathrm{~kg}$ of simulant at $5.6 \mathrm{M}$ sodium ion. Alternatively, this dilution could be made by adding $139.7 \mathrm{~mol}$ of $1.335 \mathrm{M} \mathrm{NaOH}$ solution to $889.5 \mathrm{~g}$ of simulant at $6.5 \mathrm{M}$ sodium ion to make $1.037 \mathrm{~kg}$ of simulant at $5.6 \mathrm{M}$ sodium ion.

The interaction of solution and solids is more complex when silica is present in the system. Hydroxide ion reacts with silica to form soluble silicon-containing species such as $\mathrm{H}_{2} \mathrm{SiO}_{4}{ }^{2-}$ or $\mathrm{HSiO}_{4}{ }^{3-}$. These aqueous silicon species combine to form dimers and polymers. A description of the dissolution of silica requires a large number of species so that the different combinations can be accounted for. In the model used in this evaluation, ten aqueous silica species are included.

Tables B.4-B.6 show the calculation of species in the simulant with $198 \mathrm{mg} / \mathrm{L}$ of silicon. This is the maximum concentration of silicon based on tests conducted at ORNL by Paul Taylor. The material listed as cancrinite has the formula $\mathrm{Na}_{7.68} \mathrm{Al}_{6} \mathrm{Si}_{6} \mathrm{O}_{24}\left(\mathrm{NO}_{3}\right)_{1.68}\left(\mathrm{H}_{2} \mathrm{O}\right)_{4.1}$. It contains 6 mol of aluminum and $6 \mathrm{~mol}$ of silicon per mole of cancrinite. For the silicon-containing species in solution, the first number after the silicon is the ionic charge and the second is the number of silicon atoms. For example, Si2,1 has a charge of -2 and contains 1 silicon atom.

Table B.4 lists the species calculated for the average simulant undiluted. Table B.5 gives the equilibrium species when $139.9 \mathrm{~g}$ of water and $7.479 \mathrm{~g}$ of $\mathrm{NaOH}$ are added to $889.5 \mathrm{~g}$ of the 
concentrated simulant to make a simulant $5.6 \mathrm{M}$ in $\mathrm{Na}^{+}$. The amount of gibbsite and cancrinite is the same (or very close) in the $6.4 \mathrm{M} \mathrm{Na}^{+}$and $5.6 \mathrm{M} \mathrm{Na}^{+}$solutions. Table B.6 shows the calculation where water only was added to make the dilution to $5.6 \mathrm{M} \mathrm{Na}^{+}$. More gibbsite is indicated in this case because the caustic activity is lower.

The amount of cancrinite is limited by the amount of silicon that entered the solution. If a higher caustic concentration were used with CST, the most likely result would be a decreased amount of gibbsite but an increased amount of cancrinite due to an increase in the silicon that would enter the solution.

Table B.1. Savannah River "average" waste simulant at $25^{\circ} \mathrm{C}:\left[\mathrm{Na}^{+}\right]=6.4 \mathrm{M}$; initial (mol): $\mathrm{H}_{2} \mathrm{O}=42.854, \mathrm{Na}^{+}=5.572, \mathrm{OH}^{-}=1.920$

\begin{tabular}{lllc} 
& Moles & Activity & Molality \\
\hline $\mathrm{H}_{2} \mathrm{O}$ & & & \\
$\mathrm{Na}^{+}$ & $4.2864 \mathrm{E}+01$ & $7.6700 \mathrm{E}-01$ & $5.5509 \mathrm{E}+01$ \\
$\mathrm{~K}^{+}$ & $5.5720 \mathrm{E}+00$ & $5.0090 \mathrm{E}+00$ & $7.2157 \mathrm{E}+00$ \\
$\mathrm{H}^{+}$ & $1.5000 \mathrm{E}-02$ & $9.4986 \mathrm{E}-03$ & $1.9425 \mathrm{E}-02$ \\
$\mathrm{NO}_{3}{ }^{-}$ & $2.7858 \mathrm{E}-15$ & $3.1423 \mathrm{E}-15$ & $3.6075 \mathrm{E}-15$ \\
$\mathrm{OH}^{-}$ & $2.1400 \mathrm{E}+00$ & $7.1631 \mathrm{E}-01$ & $2.7713 \mathrm{E}+00$ \\
$\mathrm{Cl}^{-}$ & $1.9407 \mathrm{E}+00$ & $2.7116 \mathrm{E}+00$ & $2.5133 \mathrm{E}+00$ \\
$\mathrm{~F}^{-}$ & $2.5000 \mathrm{E}-02$ & $2.4407 \mathrm{E}-02$ & $3.2375 \mathrm{E}-02$ \\
$\mathrm{PO}_{4}{ }^{3-}$ & $3.2000 \mathrm{E}-02$ & $3.1467 \mathrm{E}-02$ & $4.1440 \mathrm{E}-02$ \\
$\mathrm{HPO}_{4}{ }^{2-}$ & $9.9995 \mathrm{E}-03$ & $8.5049 \mathrm{E}-07$ & $1.2949 \mathrm{E}-02$ \\
$\mathrm{NO}_{2}{ }^{-}$ & $4.7744 \mathrm{E}-07$ & $5.7661 \mathrm{E}-09$ & $6.1828 \mathrm{E}-07$ \\
$\mathrm{Al}^{-}(\mathrm{OH})_{4}^{-}$ & $5.2000 \mathrm{E}-01$ & $3.8635 \mathrm{E}-01$ & $6.7340 \mathrm{E}-01$ \\
$\mathrm{CO}_{3}{ }^{--}$ & $2.7925 \mathrm{E}-01$ & $2.3399 \mathrm{E}-01$ & $3.6163 \mathrm{E}-01$ \\
$\mathrm{HCO}_{3}{ }^{-}$ & $1.6000 \mathrm{E}-01$ & $1.6111 \mathrm{E}-02$ & $2.0720 \mathrm{E}-01$ \\
$\mathrm{SO}_{4}{ }^{2-}$ & $3.2996 \mathrm{E}-06$ & $1.0560 \mathrm{E}-06$ & $4.2729 \mathrm{E}-06$ \\
$\mathrm{Al}(\mathrm{OH})_{3}$ & $1.5000 \mathrm{E}-01$ & $1.8563 \mathrm{E}-03$ & $1.9425 \mathrm{E}-01$ \\
\end{tabular}


Table B.2. Savannah River "average" waste simulant at $25^{\circ} \mathrm{C}$ diluted with water so that $\left[\mathrm{Na}^{+}\right]=5.6 \mathrm{M}$

\begin{tabular}{llll}
\hline Species & Moles & Activity & Molality \\
\hline $\mathrm{H}_{2} \mathrm{O}$ & $4.8986 \mathrm{E}+01$ & $7.9928 \mathrm{E}-01$ & $5.5509 \mathrm{E}+01$ \\
$\mathrm{Na}^{+}$ & $5.5720 \mathrm{E}+00$ & $4.1673 \mathrm{E}+00$ & $6.3139 \mathrm{E}+00$ \\
$\mathrm{~K}^{+}$ & $1.5000 \mathrm{E}-02$ & $7.8997 \mathrm{E}-03$ & $1.6997 \mathrm{E}-02$ \\
$\mathrm{H}^{+}$ & $4.6158 \mathrm{E}-15$ & $4.2187 \mathrm{E}-15$ & $5.2304 \mathrm{E}-15$ \\
$\mathrm{NO}_{3}{ }^{-}$ & $2.1400 \mathrm{E}+00$ & $6.6688 \mathrm{E}-01$ & $2.4249 \mathrm{E}+00$ \\
$\mathrm{OH}^{-}$ & $1.9642 \mathrm{E}+00$ & $2.1048 \mathrm{E}+00$ & $2.2257 \mathrm{E}+00$ \\
$\mathrm{Cl}^{-}$ & $2.5000 \mathrm{E}-02$ & $2.0336 \mathrm{E}-02$ & $2.8329 \mathrm{E}-02$ \\
$\mathrm{~F}^{-}$ & $3.2000 \mathrm{E}-02$ & $2.6477 \mathrm{E}-02$ & $3.6261 \mathrm{E}-02$ \\
$\mathrm{PO}_{4}{ }^{3-}$ & $9.9992 \mathrm{E}-03$ & $1.1149 \mathrm{E}-06$ & $1.1331 \mathrm{E}-02$ \\
$\mathrm{HPO}_{4}{ }^{2-}$ & $8.3074 \mathrm{E}-07$ & $1.0148 \mathrm{E}-08$ & $9.4136 \mathrm{E}-07$ \\
$\mathrm{NO}_{2}{ }^{-}$ & $5.2000 \mathrm{E}-01$ & $3.2984 \mathrm{E}-01$ & $5.8924 \mathrm{E}-01$ \\
$\left.\mathrm{Al}^{(\mathrm{OH}}\right)_{4}{ }^{-}$ & $2.5584 \mathrm{E}-01$ & $1.8163 \mathrm{E}-01$ & $2.8991 \mathrm{E}-01$ \\
$\mathrm{CO}_{3}{ }^{-}$ & $1.6000 \mathrm{E}-01$ & $1.3599 \mathrm{E}-02$ & $1.8130 \mathrm{E}-01$ \\
$\mathrm{HCO}_{3}{ }^{-}$ & $4.0640 \mathrm{E}-06$ & $1.1966 \mathrm{E}-06$ & $4.6051 \mathrm{E}-06$ \\
$\mathrm{SO}_{4}{ }^{-}$ & $1.5000 \mathrm{E}-01$ & $1.8659 \mathrm{E}-03$ & $1.6997 \mathrm{E}-01$ \\
$\left.\mathrm{Al}^{(\mathrm{OH}}\right)_{3}$ & $5.4157 \mathrm{E}-02$ & - & \\
\hline
\end{tabular}

Table B.3. Savannah River "average" waste simulant at $25^{\circ} \mathrm{C}$ diluted with water and $\mathrm{NaOH}$ so that $\left[\mathrm{Na}^{+}\right]=5.6 \mathrm{M}$ with no additional solids

\begin{tabular}{lllc} 
Species & Moles & Activity & Molality \\
\hline $\mathrm{H}_{2} \mathrm{O}$ & $4.8986 \mathrm{E}+01$ & $7.9591 \mathrm{E}-01$ & $5.5509 \mathrm{E}+01$ \\
$\mathrm{Na}^{+}$ & $5.5720 \mathrm{E}+00$ & $4.3082 \mathrm{E}+00$ & $6.3139 \mathrm{E}+00$ \\
$\mathrm{~K}^{+}$ & $1.5000 \mathrm{E}-02$ & $8.7382 \mathrm{E}-03$ & $1.6997 \mathrm{E}-02$ \\
$\mathrm{H}^{+}$ & $4.3780 \mathrm{E}-15$ & $3.8403 \mathrm{E}-15$ & $4.9610 \mathrm{E}-15$ \\
$\mathrm{NO}_{3}{ }^{-}$ & $1.9780 \mathrm{E}+00$ & $6.0701 \mathrm{E}-01$ & $2.2414 \mathrm{E}+00$ \\
$\mathrm{OH}^{-}$ & $2.1027 \mathrm{E}+00$ & $2.3024 \mathrm{E}+00$ & $2.3827 \mathrm{E}+00$ \\
$\mathrm{Cl}^{-}$ & $2.5000 \mathrm{E}-02$ & $1.9950 \mathrm{E}-02$ & $2.8329 \mathrm{E}-02$ \\
$\mathrm{~F}^{-}$ & $3.2000 \mathrm{E}-02$ & $2.6709 \mathrm{E}-02$ & $3.6261 \mathrm{E}-02$ \\
$\mathrm{PO}_{4}{ }^{3-}$ & $9.9992 \mathrm{E}-03$ & $1.1899 \mathrm{E}-06$ & $1.1331 \mathrm{E}-02$ \\
$\mathrm{HPO}_{4}{ }^{--}$ & $8.0467 \mathrm{E}-07$ & $9.8594 \mathrm{E}-09$ & $9.1182 \mathrm{E}-07$ \\
$\mathrm{NO}_{2}^{-}$ & $5.2000 \mathrm{E}-01$ & $3.3040 \mathrm{E}-01$ & $5.8924 \mathrm{E}-01$ \\
$\mathrm{Al}^{-}(\mathrm{OH})_{4}{ }^{-}$ & $2.7927 \mathrm{E}-01$ & $1.9868 \mathrm{E}-01$ & $3.1645 \mathrm{E}-01$ \\
$\mathrm{CO}_{3}{ }^{-}$ & $1.6000 \mathrm{E}-01$ & $1.3840 \mathrm{E}-02$ & $1.8130 \mathrm{E}-01$ \\
$\mathrm{HCO}_{3}^{-}$ & $3.7586 \mathrm{E}-06$ & $1.1086 \mathrm{E}-06$ & $4.2591 \mathrm{E}-06$ \\
$\mathrm{SO}_{4}{ }^{-}$ & $1.5000 \mathrm{E}-01$ & $1.8471 \mathrm{E}-03$ & $1.6997 \mathrm{E}-01$ \\
$\mathrm{Al}^{-}(\mathrm{OH})_{3}$ & $3.0731 \mathrm{E}-02$ & - & - \\
\hline
\end{tabular}


Table B.4. Savannah River "average" waste simulant at $25^{\circ} \mathrm{C}$, silicon species included, $\left[\mathrm{Na}^{+}\right]=6.4 \mathrm{M}$

\begin{tabular}{|c|c|c|c|}
\hline Species & Moles & Activity & Molality \\
\hline $\mathrm{H}_{2} \mathrm{O}$ & $4.2873 \mathrm{E}+01$ & $7.7125 \mathrm{E}-01$ & $5.5509 \mathrm{E}+01$ \\
\hline $\mathrm{Na}^{+}$ & $5.5630 \mathrm{E}+00$ & $4.8230 \mathrm{E}+00$ & $7.2025 \mathrm{E}+00$ \\
\hline $\mathrm{K}^{+}$ & $1.5000 \mathrm{E}-02$ & $1.0742 \mathrm{E}-02$ & $1.9421 \mathrm{E}-02$ \\
\hline $\mathrm{H}^{+}$ & $2.8316 \mathrm{E}-15$ & $3.1841 \mathrm{E}-15$ & $3.6662 \mathrm{E}-15$ \\
\hline $\mathrm{NO}_{3}^{-}$ & $2.1380 \mathrm{E}+00$ & 7.1477E-01 & $2.7681 \mathrm{E}+00$ \\
\hline $\mathrm{OH}^{-}$ & $1.9350 \mathrm{E}+00$ & $2.6908 \mathrm{E}+00$ & $2.5053 \mathrm{E}+00$ \\
\hline $\mathrm{Cl}^{-}$ & $2.5000 \mathrm{E}-02$ & $2.4342 \mathrm{E}-02$ & $3.2368 \mathrm{E}-02$ \\
\hline $\mathrm{F}^{-}$ & $3.2000 \mathrm{E}-02$ & $3.1373 \mathrm{E}-02$ & 4.1431E-02 \\
\hline $\mathrm{PO}_{4}^{3-}$ & 9.9995E-03 & $8.2631 \mathrm{E}-07$ & $1.2947 \mathrm{E}-02$ \\
\hline $\mathrm{HPO}_{4}{ }^{2-}$ & 4.7565E-07 & 5.6767E-09 & $6.1584 \mathrm{E}-07$ \\
\hline $\mathrm{NO}_{2}^{-}$ & $5.2000 \mathrm{E}-01$ & $3.8525 \mathrm{E}-01$ & $6.7325 \mathrm{E}-01$ \\
\hline $\mathrm{Al}(\mathrm{OH})_{4}^{-}$ & $2.7795 \mathrm{E}-01$ & $2.3220 \mathrm{E}-01$ & $3.5987 \mathrm{E}-01$ \\
\hline $\mathrm{CO}_{3}^{2-}$ & 1.6000E-01 & $5.8647 \mathrm{E}-03$ & $2.0715 \mathrm{E}-01$ \\
\hline $\mathrm{CU}_{3}$ & $7.0081 \mathrm{E}-07$ & $3.8950 \mathrm{E}-07$ & $9.0734 \mathrm{E}-07$ \\
\hline $\mathrm{HCO}_{3}$ & $1.5000 \mathrm{E}-01$ & $1.6143 \mathrm{E}-03$ & $1.9421 \mathrm{E}-01$ \\
\hline $\begin{array}{l}\mathrm{SO}_{4} \\
\mathrm{Si}_{1} 1\end{array}$ & $3.4008 \mathrm{E}-10$ & $1.3246 \mathrm{E}-09$ & $4.4031 \mathrm{E}-10$ \\
\hline $\begin{array}{l}\mathrm{S} 11,1 \\
\mathrm{Si2} 1\end{array}$ & $1.2810 \mathrm{E}-08$ & $1.6585 \mathrm{E}-06$ & $1.6585 \mathrm{E}-08$ \\
\hline $\begin{array}{l}\mathrm{S} 12,1 \\
\mathrm{Si} 2\end{array}$ & 5.2858E-09 & 1.0719E-09 & $6.8436 \mathrm{E}-09$ \\
\hline $\begin{array}{l}\mathrm{S} 12,2 \\
\mathrm{Si1} 2\end{array}$ & $1.1994 \mathrm{E}-08$ & $4.0386 \mathrm{E}-07$ & $1.5529 \mathrm{E}-08$ \\
\hline $\begin{array}{l}\mathrm{S} 14,2 \\
\mathrm{Si} 63\end{array}$ & $6.4258 \mathrm{E}-08$ & $2.3703 \mathrm{E}-10$ & 8.3196E-08 \\
\hline $\begin{array}{l}\mathrm{Si6}, 3 \\
\mathrm{Si} 4\end{array}$ & $1.8831 \mathrm{E}-08$ & 4.2285E-09 & $2.4380 \mathrm{E}-08$ \\
\hline $\begin{array}{l}\mathrm{Si4}, 4 \\
\mathrm{Si} 66\end{array}$ & 4.6099E-09 & 7.2952E-09 & $5.9685 \mathrm{E}-09$ \\
\hline $\mathrm{Si} 6,6$ & $1.9438 \mathrm{E}-09$ & $2.2401 \mathrm{E}-10$ & $2.5167 \mathrm{E}-09$ \\
\hline $\mathrm{Si} 4,8$ & 5.3636E-09 & $1.3521 \mathrm{E}-08$ & 6.9444E-09 \\
\hline $\begin{array}{l}\mathrm{S} 18,8 \\
\mathrm{Sin} 1\end{array}$ & $1.5385 \mathrm{E}-14$ & $2.7276 \mathrm{E}-14$ & $1.9919 \mathrm{E}-14$ \\
\hline SiO, 1 & $2.5000 \mathrm{E}-02$ & - & - \\
\hline $\begin{array}{l}\mathrm{Al}(\mathrm{OH})_{3} \\
\text { Cancrinite }\end{array}$ & $1.1750 \mathrm{E}-03$ & - & - \\
\hline
\end{tabular}


Table B.5. Savannah River "average" waste simulant diluted from $\left[\mathrm{Na}^{+}\right]=6.4 M$ to $\left[\mathrm{Na}^{+}\right]=5.6 \mathrm{M}$ with water and $\mathrm{NaOH}$, silicon species included

\begin{tabular}{|c|c|c|c|}
\hline Species & Moles & Activity & Molality \\
\hline $\mathrm{H}_{2} \mathrm{O}$ & $5.0639 \mathrm{E}+01$ & $8.0051 \mathrm{E}-01$ & $5.5509 \mathrm{E}+01$ \\
\hline $\mathrm{Na}^{+}$ & $5.7500 \mathrm{E}+00$ & $4.1146 \mathrm{E}+00$ & $6.3029 E+00$ \\
\hline $\mathrm{K}^{+}$ & $1.5000 \mathrm{E}-02$ & $9.0016 \mathrm{E}-03$ & $1.6442 \mathrm{E}-02$ \\
\hline $\mathrm{H}^{+}$ & $4.6304 \mathrm{E}-15$ & $4.0134 \mathrm{E}-15$ & $5.0757 \mathrm{E}-15$ \\
\hline $\mathrm{NO}_{3}{ }^{-}$ & $2.1380 \mathrm{E}+00$ & 6.3851E-01 & $2.3436 \mathrm{E}+00$ \\
\hline $\mathrm{OH}^{-}$ & $2.1217 \mathrm{E}+00$ & $2.2158 \mathrm{E}+00$ & $2.3258 \mathrm{E}+00$ \\
\hline $\mathrm{Cl}^{-}$ & $2.5000 \mathrm{E}-02$ & 1.9391E-02 & $2.7404 \mathrm{E}-02$ \\
\hline $\mathrm{F}^{-}$ & $3.2000 \mathrm{E}-02$ & $2.5683 \mathrm{E}-02$ & $3.5077 \mathrm{E}-02$ \\
\hline $\mathrm{PO}_{4}^{3-}$ & 9.9992E-03 & $1.0748 \mathrm{E}-06$ & $1.0961 \mathrm{E}-02$ \\
\hline $\mathrm{HPO}_{4}{ }^{2-}$ & 7.9480E-07 & 9.3073E-09 & 8.7123E-07 \\
\hline $\mathrm{NO}_{2}^{-}$ & $5.2000 \mathrm{E}-01$ & $3.1918 \mathrm{E}-01$ & $5.7000 \mathrm{E}-01$ \\
\hline $\mathrm{NU}_{2}$ & $2.7821 \mathrm{E}-01$ & $1.9121 \mathrm{E}-01$ & $3.0496 \mathrm{E}-01$ \\
\hline $\mathrm{Al}(\mathrm{OH})_{4}$ & $1.6000 \mathrm{E}-01$ & $5.4376 \mathrm{E}-03$ & $1.7538 \mathrm{E}-01$ \\
\hline $\mathrm{CO}_{3}^{2-}$ & $9.8457 \mathrm{E}-07$ & 4.5519E-07 & $1.0792 \mathrm{E}-06$ \\
\hline $\mathrm{HCO}_{3}^{-}$ & $1.5000 \mathrm{E}-01$ & $1.6419 \mathrm{E}-03$ & 1.6442E-01 \\
\hline $\mathrm{SO}_{4}{ }^{2-}$ & $4.7580 \mathrm{E}-10$ & $1.8263 \mathrm{E}-09$ & $5.2155 \mathrm{E}-10$ \\
\hline Sil, 1 & $1.6551 \mathrm{E}-08$ & $1.8143 \mathrm{E}-06$ & $1.8143 \mathrm{E}-08$ \\
\hline $\mathrm{Si} 2,1$ & $6.8522 \mathrm{E}-09$ & $1.4507 \mathrm{E}-09$ & $7.5111 \mathrm{E}-09$ \\
\hline $\mathrm{Si} 2,2$ & $1.6104 \mathrm{E}-08$ & 4.3363E-07 & $1.7652 \mathrm{E}-08$ \\
\hline $\mathrm{Si} 4,2$ & $7.7767 \mathrm{E}-08$ & $2.4981 \mathrm{E}-10$ & $8.5245 \mathrm{E}-08$ \\
\hline Si6,3 & $2.6060 \mathrm{E}-08$ & $5.6171 \mathrm{E}-09$ & $2.8566 \mathrm{E}-08$ \\
\hline $\mathrm{Si} 4,4$ & $6.1509 \mathrm{E}-09$ & $9.5121 \mathrm{E}-09$ & $6.7423 \mathrm{E}-09$ \\
\hline Si6,6 & 3.1292E-09 & $3.2792 \mathrm{E}-10$ & $3.4301 \mathrm{E}-09$ \\
\hline $\mathrm{Si} 4,8$ & $7.2466 \mathrm{E}-09$ & 1.7629E-08 & $7.9435 \mathrm{E}-09$ \\
\hline $\mathrm{Si} 8,8$ & $3.3139 \mathrm{E}-14$ & $4.7403 \mathrm{E}-14$ & $3.6326 \mathrm{E}-14$ \\
\hline $\mathrm{SiO}, 1$ & $2.4743 \mathrm{E}-02$ & - & - \\
\hline $\mathrm{Al}(\mathrm{OH})_{3}$ & $1.1750 \mathrm{E}-03$ & - & - \\
\hline Cancrinite & & & \\
\hline
\end{tabular}


Table B.6. Savannah River "average" waste simulant diluted from $\left[\mathrm{Na}^{+}\right]=6.4 M$ to $\left[\mathrm{Na}^{+}\right]=5.6 \mathrm{M}$ with only water, silicon species included

\begin{tabular}{|c|c|c|c|}
\hline Species & Moles & Activity & Molality \\
\hline $\mathrm{H}_{2} \mathrm{O}$ & $4.8995 \mathrm{E}+01$ & 8.0277E-01 & $5.5509 \mathrm{E}+01$ \\
\hline $\mathrm{Na}^{+}$ & $5.5630 \mathrm{E}+00$ & $4.0308 \mathrm{E}+00$ & $6.3025 \mathrm{E}+00$ \\
\hline $\mathrm{K}^{+}$ & $1.5000 \mathrm{E}-02$ & 8.8498E-03 & 1.6994E-02 \\
\hline $\mathrm{H}^{+}$ & $4.6878 \mathrm{E}-15$ & $4.26991 \mathrm{E}-15$ & $5.3110 \mathrm{E}-15$ \\
\hline $\mathrm{NO}_{3}^{-}$ & $2.1380 \mathrm{E}+00$ & $6.6511 \mathrm{E}-01$ & $2.4223 \mathrm{E}+00$ \\
\hline $\mathrm{OH}^{-}$ & $1.9582 \mathrm{E}+00$ & $2.0886 \mathrm{E}+00$ & $2.2186 \mathrm{E}+00$ \\
\hline $\mathrm{Cl}^{-}$ & $2.5000 \mathrm{E}-02$ & 2.0274E-02 & $2.8323 \mathrm{E}-02$ \\
\hline $\mathrm{F}^{-}$ & $3.2000 \mathrm{E}-02$ & $2.6385 \mathrm{E}-02$ & $3.6254 \mathrm{E}-02$ \\
\hline $\mathrm{PO}_{4}{ }^{3-}$ & 9.9992E-03 & $1.0818 \mathrm{E}-06$ & $1.1328 \mathrm{E}-02$ \\
\hline $\mathrm{HPO}_{4}^{2-}$ & $8.2601 \mathrm{E}-07$ & 9.9663E-09 & $9.3582 \mathrm{E}-07$ \\
\hline $\mathrm{NO}_{4}^{-}$ & $5.2000 \mathrm{E}-01$ & $3.2878 \mathrm{E}-01$ & 5.8913E-01 \\
\hline $\mathrm{NO}_{2}$ & $2.5472 \mathrm{E}-01$ & $1.8023 \mathrm{E}-01$ & $2.8859 \mathrm{E}-01$ \\
\hline $\mathrm{Al}(\mathrm{OH})_{4}{ }^{-}$ & $1.6000 \mathrm{E}-01$ & $5.5464 \mathrm{E}-03$ & $1.8127 \mathrm{E}-01$ \\
\hline $\mathrm{CO}_{3}{ }^{2-}$ & $1.0361 \mathrm{E}-06$ & 4.9397E-07 & $1.1738 \mathrm{E}-06$ \\
\hline $\mathrm{HCO}_{3}{ }^{-}$ & $1.5000 \mathrm{E}-01$ & $1.7074 \mathrm{E}-03$ & $1.6994 \mathrm{E}-01$ \\
\hline $\mathrm{SO}_{4}^{2-}$ & $4.7391 \mathrm{E}-10$ & $1.8659 \mathrm{E}-09$ & $5.3691 \mathrm{E}-10$ \\
\hline Sil,1 & $1.5378 \mathrm{E}-08$ & $1.7422 \mathrm{E}-06$ & $1.7422 \mathrm{E}-08$ \\
\hline $\mathrm{Si} 2,1$ & $6.8155 \mathrm{E}-09$ & $1.4801 \mathrm{E}-09$ & $7.7216 \mathrm{E}-09$ \\
\hline $\mathrm{Si} 2,2$ & $1.5137 \mathrm{E}-08$ & 4.1582E-07 & $1.7149 \mathrm{E}-08$ \\
\hline $\mathrm{Si} 4,2$ & $7.2081 \mathrm{E}-08$ & $2.3921 \mathrm{E}-10$ & $8.1663 \mathrm{E}-08$ \\
\hline $\mathrm{Si6}, 3$ & $2.5832 \mathrm{E}-08$ & $5.7226 \mathrm{E}-09$ & $2.9266 \mathrm{E}-08$ \\
\hline $\mathrm{Si} 4,4$ & $6.1160 \mathrm{E}-09$ & $9.6772 \mathrm{E}-09$ & 6.9290E-09 \\
\hline Si6,6 & $3.1709 \mathrm{E}-09$ & $3.4410 \mathrm{E}-10$ & $3.5924 \mathrm{E}-09$ \\
\hline $\mathrm{Si} 4,8$ & 7.2081E-09 & $1.7935 \mathrm{E}-08$ & 8.1664E-09 \\
\hline $\mathrm{Si} 8,8$ & $3.4542 \mathrm{E}-14$ & $5.1525 \mathrm{E}-14$ & 3.9134E-14 \\
\hline $\mathrm{Si0}, 1$ & $4.8225 \mathrm{E}-02$ & - & - \\
\hline $\mathrm{Al}(\mathrm{OH})_{3}$ & $1.1750 \mathrm{E}-03$ & - & - \\
\hline Cancrinite & $1.1 / 50 \mathrm{E}-\mathrm{U}$ & & \\
\hline
\end{tabular}

\section{Reference List for Appendix B}

B.1. C. F. Weber and E. C. Beahm, Chemical Modeling of Waste Sludges, ORNL/TM13200, Oak Ridge National Laboratory, Oak Ridge, Tenn., 1996.

B.2. E. C. Beahm, C. F. Weber, D. D. Lee, T. A. Dillow, R. D. Hunt, C. M. Keswa, K. Osseo-Asare, and K. E. Spear, Status Report on Solid Control in Leachates, ORNL/TM-13660, Oak Ridge National Laboratory, Oak Ridge, Tenn., July 1998. 


\section{INTERNAL DISTRIBUTION}

$\begin{array}{ll}\text { 1. } & \text { K. K. Anderson } \\ \text { 2. } & \text { D. A. Bostick } \\ \text { 3. } & \text { R. D. Hunt } \\ \text { 4. } & \text { R. T. Jubin } \\ \text { 5. } & \text { T. E. Kent } \\ \text { 6. } & \text { D. D. Lee } \\ \text { 7. } & \text { R. Lenarduzzi } \\ \text { 8. } & \text { A. J. Mattus }\end{array}$

9. C. P. McGinnis

10. L. E. McNeese

11. S. M. Robinson

13. B. B. Spencer

14-18. T. D. Welch

19. ORNL Central Research Library

20. Laboratory Records, RC

21. Laboratory Records, OSTI

\section{EXTERNAL DISTRIBUTION}

22. Jeffrey L. Barnes, Westinghouse Savannah River Company, P.O. Box 616, 704-3N, Room S162, Aiken, SC 29808

23. Joe T. Carter, Westinghouse Savannah River Company, P.O. Box 616, 704-3N, Room S151, Aiken, SC 29808

24. Dennis Fennelly, UOP LLC, 307 Fellowship Road, Suite 207, Mt. Laurel, NJ 08054

25. Samuel D. Fink, Westinghouse Savannah River Company, P.O. Box 616, 773-A, Room B112, Aiken, SC 29808

26. Mark W. Geeting, Westinghouse Savannah River Company, P.O. Box 616, 704-196N, Room S411, Aiken, SC 29808

27. Roger L Gilchrist, Pacific Northwest National Laboratory, P.O. Box 999, MS:K9-91, Richland, WA 99352

28. T. S. Gutmann, U.S. Department of Energy, Savannah River Operations Office, P.O. Box A, Aiken, SC 29802

29. J. O. Honeyman, Lockheed Martin Hanford Corporation, P.O. Box 1500, MS: G3-21, Richland, WA 99352

30. R. A. Jacobs, Westinghouse Savannah River Company, P.O. Box 616, 704-3N, Room S252, Aiken, SC 29808

31. Jim Jewett, Numatec Hanford Corporation, P.O. Box 1970, Richland, WA 99352

32. Robert T. Jones, Westinghouse Savannah River Company, P.O. Box 616, 704-3N, Room S122, Aiken, SC 29808.

33. R. A. Kirkbride, Numatec Hanford Corporation, P.O. Box 1970, MS: H5-27, Richland, WA 99352

34. C. S. Louie, U.S. Department of Energy, Richland Operations Office, P.O. Box 550, MSIN: B4-55, Richland, WA 99352

35. J. P. Morin, Westinghouse Savannah River Company, P.O. Box 616, Savannah River Technology Center, 703-H, Aiken, SC 29808

36. Lynn Nelson, Westinghouse Savannah River Company, P.O. Box 616, 773-A, Room-B-112, Aiken, SC 29808

37. J. R. Noble-Dial, U.S. Department of Energy, Oak Ridge Operations Office, P.O. Box 2001, Oak Ridge, TN 37831-8620 
38. Arlin Olson, Idaho National Engineering and Environmental Laboratory, Building 637, MS-5218, Idaho Falls, ID 83415-5218

39. L. M. Papouchado, Westinghouse Savannah River Company, P.O. Box 616, 773-A, Room A-263, Aiken, SC 29808

40. Reid Peterson, Westinghouse Savannah River Company, P.O. Box 616, 773-A, Room B-132, Aiken, SC 29808

41. S. F. Piccolo, Westinghouse Savannah River Company, P.O. Box 616, 704-3N, Room S152, Aiken, SC 29808

42. Michael Poirier, Westinghouse Savannah River Company, P.O. Box 616, 679-T, Room 2A6, Aiken, SC 29808

43. J. M. Reynolds II, U.S. Department of Energy, Savannah River Operations Office, P.O. Box A, Building 704-196N, Room S441, Aiken, SC 29802

44. Jim Rindfleisch, Idaho National Engineering and Environmental Laboratory, Building 637, MS-5218, Idaho Falls, ID 83415-5218

45. K. J. Rueter, Westinghouse Savannah River Company, P.O. Box 616, 706-S, Room 103, Aiken, SC 29808

46. W. W. Schulz, 12704 Sandia Ridge Place NE, Albuquerque, NM 87111

47. Patricia C Suggs, US Department of Energy, Savannah River Operations Office, P.O. Box A, Building 704-196N, Room S431, Aiken, SC 29802

48. J. L. Swanson, 1318 Cottonwood, Richland, WA 99352

49. W. L. Tamosaitis, Westinghouse Savannah River Company, P.O. Box 616, 773-A, Room A-231, Aiken, SC 29808

50. Larry Tavlarides, Syracus University, Dept. of Chemical Engineering \& Materials Science, 334 Hinds Hall, Syracuse, NY 13244-1190

51. T. A. Todd, Idaho National Engineering and Environmental Laboratory, Building 637, MS-5218, Idaho Falls, ID 83415-5218

52. George Vandegrift, Argonne National Laboratory, Building 205, 9700 South Cass Avenue, Argonne, IL 60439

53. J. H. Westsik, Pacific Northwest National Laboratory, P.O. Box 999, MS:K9-91, Richland, WA 99352

54. W. R. Wilmarth, Westinghouse Savannah River Company, P.O. Box 616, 773-42A, Room 153, Aiken, SC 29808

55. P. E. Woodall, U.S. Department of Energy, Idaho Operations Office, 750 DOE Place (MS 1145), Idaho Falls, ID 83402

56-62. Tanks Focus Area Technical Team, c/o B. J. Williams, Pacific Northwest National Laboratory, P.O. Box 999, MSIN K9-69, Richland, WA 99352

63. Tanks Focus Area Field Lead, c/o T. P. Pietrok, US Department of Energy, Richland Operations Office, P.O. Box 550, MS: K8-50, Richland, WA 99352 